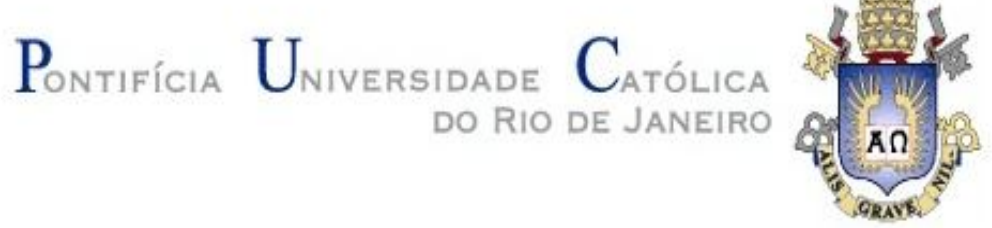

Luciana de Lacerda Dias Braga

\title{
Espaço Escolar e Trabalho Docente: memórias e representações
}

\begin{abstract}
Tese de Doutorado
Tese apresentada como requisito parcial para obtenção do grau de Doutor pelo Programa de Pós-graduação em Educação do Departamento de Educação do Centro de Teologia e Ciências Humanas da PUC-Rio.
\end{abstract}

Orientadora: Prof ${ }^{a}$ Isabel Oswald Monteiro Lelis Co-orientador: Profo Fabiano Lemos de Britto 


\section{Luciana de Lacerda Dias Braga}

\section{Espaço Escolar e Trabalho Docente: memórias e representações}

Tese apresentada como requisito parcial para obtenção do grau de Doutor pelo Programa de Pós-graduação em Educação do Departamento de Educação do Centro de Teologia e Ciências Humanas da PUC-Rio. Aprovada pela Comissão Examinadora abaixo assinada.

Profa. Isabel Alice Oswald Monteiro Lelis

Orientadora

Departamento de Educação - PUC-Rio

Profo. Fabiano de Lemos Britto

Co-Orientador

UERJ

Profa. Ana Waleska Pollo Campos Mendonça

Departamento de Educação - PUC-Rio

Profa. Patrícia Coelho da Costa

Departamento de Educação - PUC-Rio

Profa. Ana Chrystina Venancio Mignot

UERJ

Profa. Maria Luiza M. Bastos Oswald

UERJ

Prof $f^{a}$ Denise Berruezo Portinari

Coordenadora Setorial do Centro de

Teologia e Ciências Humanas

Rio de Janeiro, 09 de março de 2015. 
Todos os direitos reservados. É proibida a reprodução total ou parcial do trabalho sem autorização do autor, do orientador e da universidade.

\section{Luciana de Lacerda Dias Braga}

Luciana de Lacerda Dias Braga é mestre em Educação pela Pontifícia Universidade Católica de Petrópolis. Possui especialização em Engenharia de Segurança do Trabalho pela Universidade Federal de Juiz de Fora. Graduou-se em Arquitetura e Urbanismo pela Universidade Federal de Juiz de Fora e em Pedagogia pela Universidade Federal de Juiz de Fora. Investiga sobre o espaço na educação. Tem experiência na área de Arquitetura e Urbanismo, com ênfase em arquitetura de interiores e engenharia de segurança do trabalho e tem experiência na área de educação, mais especificamente como docente de curso técnico profissionalizante.

Ficha Catalográfica

$$
\begin{aligned}
& \text { Braga, Luciana de Lacerda Dias } \\
& \text { Espaço Escolar e Trabalho Docente: memórias e } \\
& \text { representações / Luciana de Lacerda Dias Braga; } \\
& \text { orientadora: Isabel Alice Oswald Monteiro Lélis; co- } \\
& \text { orientador: Fabiano de Lemos Britto. - 2015. } \\
& 105 \text { f.; } 30 \mathrm{~cm} \\
& \text { Tese (doutorado)-Pontifícia Universidade Católica do } \\
& \text { Rio de Janeiro, Departamento de Educação, 2015. } \\
& \text { Inclui bibliografia } \\
& \text { 1. Educação - Teses. 2. Espaço Escolar. 3. Trabalho } \\
& \text { Docente. 4. Memórias. 5. Representações. I. Lelis, Isabel } \\
& \text { Alice Oswald Monteiro. II. Lemos, Fabiano. III. Pontifícia } \\
& \text { Universidade Católica do Rio de Janeiro. Departamento } \\
& \text { de Educação. IV. Título. }
\end{aligned}
$$

CDD: 370 
"A duas pessoas que sempre souberam que eu era capaz de realizar um trabalho de qualidade, e que me ajudaram a me tornar a pessoa que sou hoje: Mãe e Pai." (Frances e Marcos) 


\section{Agradecimentos}

Agradecer se tornou complicado... São tantas as pessoas que durante o curso de doutorado foram atenciosas, solícitas, amigas e companheiras... Os agradecimentos que escrevo aqui (com certeza absoluta) não demonstram nem metade da minha gratidão e admiração.

À Professora Isabel Lelis, minha orientadora, que ajudou a tornar essa pesquisa um trabalho prazeroso, por ter apostado na minha capacidade, por ser uma profissional competente, dedicada e comprometida e por ter permitido construirmos uma relação de amizade.

Ao Professor Fabiano Lemos, meu co-orientador, que também tornou essa pesquisa um trabalho prazeroso, por ter acreditado no meu tema, por ser um profissional competente e por estar sempre por perto.

À Professora Waleska Mendonça, que esteve presente em momentos decisivos no caminho do doutorado seja participando das bancas de qualificação, seja em conversas de corredor, seja em congressos.

À Professora Patrícia Coelho, que participou das bancas de qualificação e colaborou com suas observações e contribuiu para a realização do meu trabalho.

Aos Professores Ana Crystina Mignot, Maria Luiza Oswald, Pedro Garcia e Zena Eizenberg, por terem reservado parte de seus tempos e terem aceitado fazer parte da minha banca de defesa.

Aos Professores do Programa de Pós-Graduação em Educação da PUC-Rio, pelo conhecimento partilhado com gentileza e dedicação.

À equipe da secretaria do Departamento de Educação da PUC-Rio, pelo apoio e gentileza.

À PUC-Rio e a FAPERJ pelos auxílios concedidos, indispensáveis a realização desta pesquisa.

Aos professores entrevistados, cujos depoimentos tornaram possível a minha pesquisa.

Aos meus amigos, pela força e paciência com a minha falta de tempo.

E, finalmente, à minha família, em especial, à minha mãe pela força e dedicação.

Espero ser uma Mãe como você para o João Gabriel que está chegando. 
Um livro [uma tese] é como uma casa. [...] Pois bem: recebo o leitor nessa casa com todos os sentimentos. $O$ primeiro diz, naturalmente, da hospitalidade com que espero acolher aqui quem vem procurar alguma coisa. Conversa séria ou fiada, conselho, sabedoria ou material de trabalho e pesquisa [...] até mesmo diversão e pretexto para uma discordância severa e segura. (Roberto Da Matta) 


\section{Resumo}

Braga, Luciana de Lacerda Dias. Lelis, Isabel Alice Oswald Monteiro. Britto, Fabiano de Lemos. Espaço Escolar e Trabalho Docente: memórias e representações. Rio de Janeiro, 2015. 105p. Tese de Doutorado Departamento de Educação, Pontifícia Universidade Católica do Rio de Janeiro.

Esta tese é um estudo sobre memórias dos espaços escolares vividos por professores. Procura identificar as condições e dimensões do trabalho docente a partir do espaço escolar e memórias sobre a jornada educativa de dezessete professores de Ensino Superior e Ensino Médio de um município de Minas Gerais As memórias foram colhidas por meio de entrevista semiestruturada. Essas memórias de um tempo e espaço vividos pelos professores entrevistados formam uma narrativa do passado que se entrelaça no presente, criando significados na forma de sua atividade docente. Dessa forma, o fio condutor de todo o trabalho são as memórias do espaço escolar. Tanto o espaço, quanto o trabalho docente são construções sociais interdependentes, que são influenciadas pela trajetória de vida, cultura e formação do sujeito. As análises são fundamentadas em estudos sobre arquitetura/espaço (Bachelard, Viñao-Frago, Escolano), cultura visual (Hernández), espaço/relações de poder (Foucault), memória (Bergson, Bosi) e estudos sobe docentes (Tardiff, Raymond). O espaço escolar causa impactos objetivos e subjetivos em seus usuários. Nesse sentido, o espaço é produtor de identidades, símbolos e relações que exercem influencia no trabalho docente. Dessa forma, a partir das falas dos professores pode-se perceber que: embora as ideias e práticas pedagógicas sejam ligadas ao contexto político, social e tecnológico, esse último é o mais percebido e, quanto ao uso do espaço, o professor sente-se aprisionado por imposições superiores como decisões da direção escolar, exames nacionais e conteúdo da disciplina.

\section{Palavras-chave}

Espaço Escolar; Trabalho Docente; Memórias; Representações. 


\section{Abstract}

Braga, Luciana de Lacerda Dias. Lelis, Isabel Alice Oswald Monteiro (Advisor). Britto, Fabiano de Lemos (Co-Advisor) Scholl Space and Teaching Work: memories and representation. Rio de Janeiro, 2015. 105p. Doctoral Thesis. Departamento de Educação, Pontifícia Universidade Católica do Rio de Janeiro.

This thesis is a study of memories of school spaces experienced by teachers. The goal is to identify the conditions and dimensions of teachers' work from the scholar environment and memories of the educational journey of seventeen teachers working in higher education and in high school in a city in Minas Gerais. The memories were collected through semi-structured interviews. These memories of a time and space experienced by the teachers interviewed form a narrative of the past that blends with the present time, creating meanings in his teaching activities. Thus, the common thread of this work are the memories of school space. Both the space, as the teaching are interdependent social constructs, which are influenced by the life, culture and formation of the subject. The analyzes are based on studies of architecture / space (Bachelard, Viñao-Frago, Escolano), visual culture (Hernández), space / power relations (Foucault), memory (Bergson, Bosi) and studies about teachers (Tardiff, Raymond). The school environment causes subjective and objective impacts on their inhabitants. In this sense, space produces identity, symbols and relationships which influence on teaching. Thus, from the teachers' speeches can be seen that: although the ideas and teaching practices are linked to political, social and technological context, the latter is the most noticed and, for the use of space, the teacher feels trapped by higher decisions of the school board, national tests and content of the discipline.

\section{Keywords}

Scholl Space; Teaching Work; Memory; Representations 


\section{Sumário}

1. Introdução 10

2. Construção Pesquisa 14

2.1. Contornos da pesquisa: Objetivo, problematização, 17

metodologia

2.2. Recorte teórico/conceitual e metodologia 20

2.2.1. Cultura visual e espaço escolar: memórias e representações 27

2.3. Instrumentos de investigação 29

2.3.1. Os atores da pesquisa 33

3. Espaços e tempos de aluno: memórias dos professores 40

3.1. Memórias que se intercruzam 41

3.2. Sabores e cheiros, afeto, carinhos e desconfortos: espaços 44 afetivos

3.3. Espaços de alívio: heterotopias 48

3.4. Espaço e Gênero e diversidade sexual 50

3.5. Espaço e vigilância 52

4. Espaços e tempos de professor: construções e representações 56 espaciais

4.1. Espaço e poder 59

4.2. Práticas e ideias pedagógicas 64

4.3. Espaço e conteúdo da disciplina 68

4.4. Espaço e controle: imposições 70

4.5. Público x Privado 74

4.6. Cheio ou vazio: questão de percepção - número de alunos em 81 sala de aula

5. Memórias e Práticas 86

5.1. Memórias e Práticas: imagens sobre o espaço escolar 92

6. Considerações Finais 95

7. Referências Bibliográficas 99

$\begin{array}{ll}\text { 8. Anexo } & 104\end{array}$ 


\section{Introdução}

[...] todo espaço é lugar percebido. A percepção é um processo cultural. Por isso, não percebemos, senão lugares, isto é, espaços elaborados, construídos. Espaços com significados e representações de espaços. Representações de espaços que visualizam ou contemplam, que se rememoram ou recordam, mas que sempre levam consigo uma interpretação determinada. (VIÑAO-FRAGO, 2001, p.78)

Esse é um estudo sobre memórias dos espaços escolares vividos por professores. Essas memórias foram colhidas por meio de entrevistas semiestruturadas com docentes que tinham em comum, além da profissão professor, habitarem o mesmo espaço social: um município em Minas Gerais.

Esse trabalho procura construir um conceito dinâmico de espaço, além de tentar perceber como o espaço escolar é apropriado de diversas formas por seus habitantes. Nessa perspectiva, essa investigação é uma abordagem do espaço escolar e como ele é representado por professores. É necessário ressaltar que essa não é uma pesquisa sobre a materialidade do espaço escolar, por isso não utilizo estudos específicos sobre cultura material escolar ou sobre arquitetura escolar. $\mathrm{O}$ espaço escolar foi reconstruído pelas memórias dos entrevistados e nenhum espaço rememorado foi visitado por mim, embora conhecesse a maioria deles. Dessa forma, a memória é âncora e plataforma da pesquisa.

Dessa forma, a pesquisa também procurou identificar as condições e dimensões do trabalho docente a partir do espaço escolar e memórias sobre a jornada educativa ${ }^{1}$ de dezessete professores de Ensino Superior e Ensino Médio ${ }^{2}$ de um município de Minas Gerais. Dessa forma, procura perceber como o professor compreende os espaços que vivencia enquanto profissional e os espaços que vivenciou em seus tempos de aluno.

Pesquisar o espaço escolar é colocar-se em um processo de desnaturalização do espaço e de saberes, de voltar-se sobre si mesmo e separar da realidade um objeto de estudo que está presente em nossas vidas desde a infância e que

1 Chamo de 'memórias sobre a jornada educativa' as memórias do professor sobre seus tempos e vivências do espaço escolar durante a escolarização e a formação, incluindo suas experiências enquanto profissional, isto é, são memórias sobre os tempos de escola e sobre sua atuação como professor que influenciam em suas vivências atuais do espaço escolar.

${ }^{2}$ No capítulo 3, no item "3.1- Os atores da pesquisa" explicarei melhor a escolha desse grupo professores de Ensino Médio e professores de Ensino Superior. 
ocupamos por boa parte de nossas vidas. Nesse processo de ocupação do espaço escolar, vamos sendo formados e ao mesmo tempo vamos formando e construindo esse espaço, ou seja, a união entre a essência material da vida e a atividade humana. Nessa perspectiva, espaço é "definido como um conjunto indissociável de sistemas de objetos e de sistemas de ações" (SANTOS, 2008b, p.21). Esse conceito de espaço converge com o de Viñao-Frago (2001). Para ele, espaço "é algo físico, material, mas também uma construção cultural" (VIÑAO-FRAGO, 2001, p.77). Nesse sentido, o território escolar é um espaço demarcado e mais ou menos permeável que configura uma pedagogia e uma racionalidade; materialidade e imaterialidade que entrelaçadas constroem lugares. ${ }^{3}$

$\mathrm{Na}$ escola encontramos uma rede de múltiplos espaços concebidos e construídos pelos sujeitos atores desse cenário. A escola é um espaço histórica e socialmente produzido pelos seus atores no seu fazer cotidiano e a partir de representações sociais. Nesse cenário, a escola contemporânea enfrenta vários desafios: globalização; novas exigências de qualificação do trabalhador; políticas de avaliação de desempenho da escola, dos alunos e dos professores; diversidade cultural; diferentes tipos de acesso à informação; novas tecnologias; currículo; violência e fracasso escolar.

Geralmente, pesquisas sobre o trabalho docente levam em conta à cultura, a identidade, as práticas cotidianas, as relações de poder, o multiculturalismo, malestar docente e outros enfoques, mas não refletem sobre o espaço e como ele interfere nas práticas pedagógicas e na formação do professor. Muitos estudos, como Nóvoa (1999), Perrenoud (1999), Lüdke e Boing (2004), Sampaio; Marin (2004) e Tardif e Lessard (2008), buscam ressignificar o trabalho docente a fim de encontrar caminhos que indiquem uma forma diferente de docência que consiga enfrentar os desafios que a escola contemporânea enfrenta, mas dificilmente alguma pesquisa utiliza o espaço escolar como objeto de pesquisa e investiga como ele influência na prática docente ou no quanto o professor se subordina ao espaço escolar ou às suas representações sobre o mesmo.

O espaço educa, em boa parte, pelas mãos dos professores, que podem aceitar o espaço dado ou modificá-lo de acordo com suas necessidades e as necessidades dos alunos. O professor pode ressignificar o espaço escolar e criar

\footnotetext{
${ }^{3}$ Lugar é entendido como área física mais as relações e identidades criadas nele.
} 
novas representações sociais do que é ser docente. Dessa forma, a compreensão do professor a respeito do espaço e de como ele influencia seu trabalho cotidiano é importante.

O espaço é vivido diariamente e por isso tem-se a falsa impressão de conhecê-lo bem, mas a percepção do espaço é influenciada pela memória, (pre)conceitos, sentimentos e valores. Podemos falar que essa forma de perceber/criar o espaço escolar influencia nas representações sociais de trabalho docente e no fazer cotidiano do professor?

A escola e os professores não podem ignorar o fato de que o espaço educa, é um componente curricular e assim, como a educação, não é neutro. A naturalização do espaço e a falta de percepção de sua influencia nas práticas pedagógicas dificulta o entendimento espontâneo e articulado do espaço pelo indivíduo, por isso, acho necessário que pesquisas acerca desse tema, principalmente na área da educação, sejam realizadas.

Considero necessário investigar como as noções de espaço e suas relações com a educação escolar são tratadas pela escola, tanto do ponto de vista do professor, quanto pela própria organização e constituição sócio-espacial da instituição.

Neste trabalho, dou prioridade ao espaço como elemento de discussão da formação do professor, mas isso não impede que, em alguns momentos, apareçam algumas relações com o tempo, embora eu não vá desenvolvê-las, mas tenho consciência que espaço e tempo estão sempre em relação. "Assim como o tempo desenrola-se no espaço, para nós não faz sentido pensar um espaço fora do tempo" (VEIGA-NETO, 2007, p. 251).

Diante do que foi exposto, apresento o modo como este trabalho foi organizado. O grande eixo organizador dessa tese é a 'memória', mais especificamente as memórias do espaço escolar vivido. Pelas memórias podemos perceber as diferentes formas de percepção do espaço escolar pelo professor em seus tempos de aluno, em seus tempos de professor e como essas memórias influenciam ou não a configuração de habitar esse espaço. Essas memórias dos espaços vividos deixam transparecer as experiências espaciais que são guiadas de acordo com 'orientações individuais' e 'orientações culturais'. Esse caráter pessoal e social das memórias é o que permite que essa pesquisa seja pontual, 
específica de um grupo artificial escolhido para a pesquisa, mas também, possa ter uma abrangência mais ampla no estudo das memórias e espaço escolar.

Assim como Ecléa Bosi, em seu estudo 'Memória e Sociedade: Lembranças de Velhos' (1994), o interesse nas memórias dos professores entrevistados está no que foi lembrando, no que foi escolhido para ser dito. Dessa forma, as entrevistas criaram uma memória-espaço escolar ou uma memória espacial sobre tempos de aluno e tempos de professor. Nesse sentido, nos pareceu mais natural apresentar essas memórias em capítulos separados e depois em outro capítulo distinto apresentar inferências de como as vivências do espaço escolar enquanto aluno influenciam no modo de lidar com o espaço enquanto profissionais, enquanto docentes.

Dividimos a tese da seguinte forma:

- A introdução, o capítulo 1,2 e 3 são as partes onde o objeto de pesquisa é consolidado. O capítulo 1 traz os objetivos, problematização e metodologia, Já o capítulo 2 busca esclarecer o recorte conceitual e metodológico da pesquisa, enquanto que o capítulo 3 busca esclarecer os instrumentos de investigação e quem são os sujeitos da pesquisa.

- Os capítulos 4 e 5 trazem as memórias. No capítulo 4, estão retratadas as memórias dos professores entrevistados de seus tempos enquanto alunos, suas vivências no espaço escolar, enquanto que no capítulo 5, relatamos as construções e representações espaciais dos professores entrevistados nas suas práticas enquanto docentes.

- O capítulo 6 procura fazer uma relação entre as práticas profissionais dos professores e suas memórias sobre o espaço escolar.

- O Fechamento desta tese acontece nas considerações finais, nas referências bibliográficas e o roteiro de entrevista como anexo.

Como usamos muitos trechos das entrevistas, para dar um maior destaque às falas dos professores e diferenciá-las das citações, elas estão transcritas em itálico, entre aspas, com recuo 2, sem diminuição da fonte. Além disso, aparecerão partes das falas grifadas. Esses grifos foram feitos por mim para evidenciar partes mais relevantes dos trechos transcritos nessa tese. 


\section{Construção da pesquisa}

[...] por mais parcial que seja seu objeto - uma simples imagem -, não deixa de ter uma grande repercussão psíquica. (BACHELARD, 2008, p.3)

Este capítulo conta como o objeto de pesquisa foi construído e apresenta as questões da pesquisa, objetivos, recorte conceitual e instrumentos de investigação.

A história desta pesquisa se confunde com a minha trajetória como pessoa, como aluna e como educadora. Desta forma, esse trabalho é um pouco do que sou, por isso acho necessário expor aqui episódios da minha vida que me instigaram a ter como objeto de pesquisa o espaço escolar.

Frequento o espaço escolar desde os cinco anos de idade e nele fui me formando. Aprendi os conteúdos de algumas disciplinas, a me relacionar socialmente, a me comportar, a reconhecer símbolos, a obedecer a regras e a viver o espaço escolar de uma determinada forma, a perceber o espaço escolar por imagens e como uma imagem. Para mim isso era natural, e não uma construção, pois fazia parte da rotina da escola, não podia imaginar que existisse outra forma de construir essa experiência. Foi dessa forma que segui meu caminho na escola até chegar à universidade.

Escolhi o curso de Arquitetura e Urbanismo porque sempre me chamou atenção a falta de ergonomia nos espaços públicos, como escadas com espelho muito alto ou piso muito estreito, balcões para atendimento ao público que dificultam o acesso de crianças e deficientes, móveis escolares que não atendem a todas as faixas etárias dos alunos.

Quando estava no $3^{\circ}$ período de Arquitetura e Urbanismo da $\mathrm{UFJF}^{4}$ entrei em contato com a pesquisa acadêmica e com as comunidades assentadas na beira do Leito da Leopoldina (bairros Grama e Ladeira) e a comunidade Jardim Casablanca através do projeto de extensão "Levantamento Arquitetônico e Urbanístico em Comunidades Carentes de Juiz de Fora". Por meio de entrevistas com moradores dessas comunidades e de observações dos locais pude entender que eles percebiam, utilizavam e construíam o espaço de forma diferente da

\footnotetext{
${ }^{4}$ Universidade Federal de Juiz de Fora.
} 
aprendida na faculdade como a mais adequada. Para eles, aquele era o modo de vida e distribuição do espaço que eles prezavam e que melhor atendiam as suas necessidades e percepções de o que é habitar, o que é vizinhança, o que é um bairro. A partir daí percebi que existiam várias visões e formas de utilização do espaço que podiam e deviam ser estudadas e valorizadas. Foi nesse momento que minhas inquietações a respeito do uso do espaço começaram.

No meu percurso de cinco anos na faculdade de Arquitetura presenciei fatos que me fizeram questionar a postura de alguns professores e de como deveria ser o processo ensino-aprendizagem. Nesse momento surgiu a vontade de tornar-me professora. Vontade que ficou adormecida por algum tempo, pois sentia muito prazer em projetar e me contentava em orientar e ensinar os estagiários do escritório onde eu trabalhava.

Como a profissão de arquiteta é muito prática, sentia falta da pesquisa e a vontade de ser professora crescia a cada dia. Resolvi, então, fazer Pedagogia atraída pela possibilidade de pesquisas, discussões e contato com novas ideias. Escolhi Pedagogia esperando que o curso oferecesse bastante leitura e me proporcionasse melhor conhecimento do ser humano e ao mesmo tempo valorizasse novas formas de docência.

Durante os quatro anos de graduação em Pedagogia na UFJF vivenciei uma série de experiências que me levaram a pensar e repensar o espaço escolar. Achava o prédio da Faculdade de Educação muito descuidado ${ }^{5}$ e isso me incomodava muito. Perguntava para os outros alunos se aquilo não os incomodavam e a resposta que recebia frequentemente era que o ambiente descuidado seria uma forma de nos acostumarmos com o estado das escolas públicas que iríamos trabalhar no futuro. Outra questão era que a organização espacial das salas do curso de Pedagogia era mais tradicional que a das salas do curso de Arquitetura ${ }^{6}$. As pessoas naturalizavam ${ }^{7}$ o espaço, não pensavam uma forma diferente de construí-lo.

\footnotetext{
${ }^{5}$ Em 2001, o corredor de salas da faculdade de Educação estava precisando repintar e passar por uma reforma de manutenção. Os prédios da Faculdade de engenharia onde funcionava o curso de Arquitetura e Urbanismo eram muito bem conservados. Atualmente, a Faculdade de Educação da UFJF está em bom estado de conservação.

${ }^{6}$ A organização da sala de Pedagogia era a organização tradicional: carteiras em fileiras, mesa do professor à frente e pouco espaço físico para diferenciar a disposição do mobiliário, às vezes as carteiras eram dispostas em círculo. Já as salas de Arquitetura eram mais amplas, permitiam a de
} 
Como arquiteta, creio que percebia melhor a influência do ambiente físico na formação da memória, no conforto, acessibilidade e interesse que este poderia causar. Após cursar Pedagogia e, também, por ter participado de um grupo de pesquisa multidisciplinar do Núcleo de Educação em Ciência, Matemática e Tecnologia (NEC)- Faculdade de Educação da UFJF: “Noção de espaço escolar: múltiplos olhares", a ideia que possuía sobre o espaço evoluiu: as relações, memórias, identidades, ações e práticas pedagógicas são componentes importantes do espaço e suas representações.

$\mathrm{Na}$ minha monografia ${ }^{8}$ de final de curso de Pedagogia pesquisei como professores de $1^{\mathrm{a}}$ a $4^{\mathrm{a}}$ séries e alunos da $1^{\mathrm{a}}$ série do Ensino Fundamental de uma escola pública de um município de Minas Gerais criavam e utilizavam seus espaços. Já no mestrado ${ }^{9}$ estudei o tema espaço na Educação de Jovens e Adultos (EJA), como os alunos vivenciam e significam o espaço escolar. As duas pesquisas partiram do espaço físico para o espaço das relações e percepções de seus habitantes.

Após a conclusão dessas duas pesquisas minhas inquietações a respeito do espaço aumentaram: o espaço é formador das identidades ou é um produto delas? Quais os mecanismos de apreensão e aprendizagem do uso dos espaços pelos alunos (crianças e adultos)? Pelos professores? Como os modelos pedagógicos influenciam o espaço escolar? Como os professores compreendem os diferentes espaços de aprendizagem que vivenciam? Como as memórias de espaços vividos anteriormente influenciam na forma de habitar um espaço no presente?

Ambas as pesquisas partiam do espaço concreto, vivido no presente pelos entrevistados e, em certa forma, vivido e percebido também por mim. Agora, nesta pesquisa, o espaço além de objeto de pesquisa é princípio teórico metodológico, um orientador da investigação, pois o espaço virá das lembranças de experiências escolares dos professores, de suas memórias do espaço vivido, isto é, tento ver o espaço escolar pelo olhar do outro. Essas memórias são imagens

mudança do mobiliário o que ocorria frequentemente: em fileira, em círculo, em grupo, em dupla, espalhados, em pé, sentados, dentro e fora da sala de aula.

${ }^{7}$ Naturalizar o espaço é percebê-lo como algo natural, comum, que existe, posto no mundo. Em outras palavras, naturalizar o espaço é não percebê-lo como uma construção histórica, cultural e social.

${ }^{8}$ Título da monografia: Arquitetura, Pedagogia e uma Escola em Prédio Histórico...

${ }^{9}$ Fiz o mestrado na Universidade Católica de Petrópolis. 
que expressam o processo de vivência e apropriação do espaço pelos professores. Nessa perspectiva, utilizaremos os conceitos de cultura visual ${ }^{10}$, especialmente a visualidade (o ato de ver como ato social e histórico, influenciada por determinações discursivas de um grupo ou de uma sociedade) como um dos aportes teóricos de análise do material recolhido pela pesquisa. Trata-se de uma estratégia para entender as relações do sujeito e das experiências espaciais/visuais. Nesse sentido, isso nos leva à questionar a visão como dado natural, assim como a universalidade da experiência espacial/visual e admitir a especificidade cultural da visualidade e da percepção do espaço.

\subsection{Contornos da pesquisa: Objetivo, problematização, metodologia}

Esta investigação tem como objeto de estudo a compreensão do professor sobre os espaços que vivencia como docente e vivenciou enquanto aluno na escola e como essas vivências constroem a sua prática pedagógica e sua representação do trabalho docente, pois a ideia do que é ser professor, do que é escola influência na forma de ser professor.

As questões norteadoras dessa pesquisa são: Os professores repetem em sala de aula a configuração de espaço escolar vivido em sua escolarização? Reproduzem a noção de escola, de espaço, de relação, de educação que viveram ou que estão em sua memória? As formas de perceber/criar o espaço escolar influenciam nas representações sociais de trabalho docente e no fazer cotidiano do professor?

Os objetivos dessa pesquisa são:

- Identificar os espaços de aprendizagem vivenciados por professores em sua vida por meio de entrevistas;

- Identificar como professores percebem o espaço escolar no seu dia a dia;

- Investigar os mecanismos de construção e apropriação dos espaços da escola;

${ }^{10}$ Os estudos cultura visual buscam identificar como a complexa experiência do ver (visualidade) é algo cultural e influencia na construção da identidade e das representações. 
- Identificar como o espaço e sua construção afetam a prática pedagógica;

- Discutir até que ponto a reflexão sobre o espaço é um elemento de formação do professor.

As ciências sociais são centradas no discurso, pois o caráter de um fenômeno social não é algo que tem inerente a objetividade. Nesse sentido, o fenômeno social está condicionado pela orientação do nosso interesse de conhecimento. Dessa forma, não existe análise científica puramente objetiva, fora da vida cultural por isso, a pesquisa acontece nas conexões conceituais entre problemas. Esse caráter argumentativo das ciências sociais faz com que em uma pesquisa existam várias formas de olhar o mundo social e isso demanda justificação, explicação, argumentação, compreensão e interpretação. Neste ponto, percebo a necessidade de trabalhar com conceitos claros, que são um quadro de pensamento que auxilia a estruturar o pensamento e a organizar os dados levantados durante a pesquisa.

Essa pesquisa tem como foco fundamental o espaço escolar e os principais autores/interlocutores escolhidos para esse estudo são Michel Foucault, Gaston Bachelard com o livro 'A Poética do Espaço'.

Foucault e Bachelard são os interlocutores privilegiados desta pesquisa, pois os dois autores trazem discussões sobre o espaço e formas complementares de estudá-lo. Para Foucault estudar o espaço e sua apropriação é ao mesmo tempo um estudo dos poderes (FOUCAULT, 2008c). E “... o poder produz; ele produz realidade; produz campos de objetos e rituais da verdade. O indivíduo e o conhecimento que dele se pode ter se originam nessa produção" (FOUCAULT, 2009b, p.161). Nesse contexto, o poder, ao mesmo tempo em que coexiste no espaço escolar, o produz, portanto vemos os espaços presentes através dos saberes construídos pelas relações de poder. Dessa forma, podemos entender que o espaço é uma construção e, por ser uma representação, é percebido por meio de representações.

Bachelard (2008) traz a ideia de memória e imaginação como construtora das vivências e percepções espaciais, indicando que o espaço é ao mesmo tempo material (físico), simbólico e relacional. O mesmo autor mostra que os valores da intimidade do espaço e do aconchego influenciam na forma de se utilizar e/ou perceber os espaços. Nesse sentido, espaço e imagem estão associados, o que 
permite que a lembrança de um espaço vivido seja uma imagem única e pessoal que fica guardada na memória e acaba por influenciar a percepção de outros espaços.

(...) memória e imaginação não se deixam dissociar. Ambas trabalham para seu aprofundamento mútuo. Ambas constituem na ordem de valores, uma união da lembrança com a imagem. Assim, a casa [e porque não a escola] não vive somente no dia-a-dia, no curso de uma história, na narrativa de nossa história. Pelos sonhos, as diversas moradas de nossa vida se interpenetram e guardam os tesouros dos dias antigos (BACHELARD, 2008, p.25).

Levando em conta essa linha de pensamento de Bachelard, Foucault (2009a) propõe o conceito de um tipo de espacialidade: as heterotopias, espaços reais que abrigam o imaginário, o lúdico. Elas têm caráter local e universal e nelas há a representação de posicionamentos culturais. As heterotopias podem se modificar durante o tempo, durante a história e podem justapor vários espaços. Elas presumem um sistema de abertura e fechamento, que as isolam, mas ao mesmo tempo as deixam permeáveis. Só se pode entrar se tiver permissão ou se cumprir determinadas exigências impostas pela sociedade, cultura ou comunidade. Além disso, elas têm a função, ou "de criar um espaço de ilusão que denuncia como mais ilusório ainda qualquer espaço real, todos os posicionamentos no interior dos quais a vida humana é compartimentalizada" (FOUCAULT, 2009a, p.420). Ou a função de gerar um espaço meticulosamente perfeito "tão bem arrumado quanto o nosso é desorganizado, mal disposto e confuso" (FOUCAULT, 2009a, p.421), uma heterotopia de compensação.

Podemos entender as heterotopias como construções sociais e comunitárias que têm como propriedade atribuir novos significados aos espaços nos quais os posicionamentos são invertidos, fazendo com que essas (as heterotopias) sejam "lugares reais que parecem estar em oposição em relação aos lugares comuns em que vivemos" (VEIGA-NETO, 2007, p.249).

Dessa forma, a partir dessa conceituação de espaço, podemos falar que os conceitos de memória e representação estão atrelados à vivência e percepção do espaço escolar. Nessa perspectiva, essa percepção do espaço, é uma forma de visualidade, pois a imagem não é somente estética, ela está impregnada do papel social e cotidiano do espaço vivido. Nessa perspectiva, podemos vincular a cultura visual e seu conceito de visualidade como uma forma de interpretar as memórias de espaço escolar dos sujeitos dessa pesquisa. 


\subsection{Recorte teórico/conceitual e metodologia}

Com relação ao espaço, poder-se-ia fazer a mesma afirmação de Agostinho. Não é fácil dizer o que seja, embora vivamos imersos na experiência do mesmo. (LARA, 2007, p.12)

Apresento neste item a discussão conceitual da pesquisa.

Essa pesquisa pretendeu estudar as memórias e representações do espaço escolar pelos professores e a influência das mesmas no seu trabalho como docente. Dessa forma, os conceitos chave foram: espaço/espaço escolar, representações sociais e memória, cultura visual/visualidade. Abaixo apresento esses conceitos e faço deliberações das implicações dos mesmos para a investigação.

As representações são sistemas de valores, ideias e práticas que constroem condutas sociais e facilitam a comunicação entre pessoas de um mesmo grupo. De forma simplificada, as representações sociais são formadas a partir de experiências e esquemas já estabelecidos e construídos para um objeto. Esses esquemas e experiências são organizados e formam conceitos que passam por um processo de naturalização, adquirindo materialidade o que contribui para a construção de relações. Esses processos estão ligados um ao outro e são moldados por fatores sociais. De acordo com Chartier (1990, p.17),

as representações do mundo social assim construídas, embora aspirem à universalidade de um diagnóstico fundado na razão, são sempre determinadas pelos interesses de grupo que as forjam. Daí, para cada caso, o necessário relacionamento dos discursos proferidos com a posição de quem os utiliza.

"As representações sociais são modalidades de pensamento prático orientadas para a compreensão e o domínio do ambiente social, material e ideal" (ALVES-MAZZOTTI, 1994, p.65). Nessa perspectiva, o espaço escolar pode ser visto como uma representação que constrói representações sociais sobre a escola e sobre o trabalho docente ao mesmo tempo em que é construído por essas representações. Em outras palavras, o duplo caráter do espaço - físico e simbólico - e as duas faces da representação - figurativa e simbólica ajudam a traçar a forma de vivência, construção, percepção do que é escola e educação e esboça a construção de um sentido para a docência, a experiência de vivê-la e a forma de lidar com o ser professor. 
As representações sociais são guias de leitura do mundo (DORTIER, 2010), são variáveis segundo as disposições dos grupos ou classe social, almejam à universalidade, mas sempre são determinadas pelos interesses dos grupos que as forjam por poder e dominação (CHARTIER, 1990). Dessa forma, as representações não são discursos neutros e influenciam na percepção do professor do que é escola e do que é educação, pois "as representações são como matrizes de práticas construtoras do próprio mundo social" (CHARTIER, 1991, p.183). As representações sociais do que é 'ser bom professor' construídas pela sua vivência como aluno (memória) e por seu grupo profissional são determinantes em sua forma de dar aula e construir/vivenciar o espaço escolar.

As representações são construções culturais e sociais e de acordo com Bergson (2010), as representações não surgem da percepção, mas da participação da memória, após a percepção ter feito um recorte da realidade exterior. Dessa forma,

a memória, como propriedade de conservar certas informações, remete-nos em primeiro lugar a um conjunto de funções psíquicas, graças às quais o homem pode atualizar impressões ou informações passadas, ou que ele representa como passadas. (LE GOFF, 2012, p.405)

Nesse sentido, a memória não é uma simples reconstrução do passado, mas representações construídas a partir deste. Nessa perspectiva, podemos falar que representações e memória se entrelaçam.

Para Bergson (2010, p.5), "a lembrança [...] representa precisamente o ponto de interseção entre o espírito e a matéria", dessa forma, a memória participa da narrativa dos indivíduos e dos grupos, ordena o pensamento e a reflexão, propicia novas ideias. Essa característica faz da memória um fenômeno tanto individual e psicológico, quanto coletivo e social.

Trabalhando com a memória e com o espaço vivido, estamos invariavelmente trabalhando com o tempo. Nesse sentido, espaço e tempo "precisam ser considerados em conjunto" (SPOSITO, 2004, p.87). A memória traz o passado e reitera o presente, influência no futuro, pois o passado é "como uma parte integral da existência [...] corrói incessantemente o futuro. Tudo depende da maneira pela qual abordamos o passado" (GIEDION, 2004, p.13) por isso, "a distinção entre passado e presente é um elemento essencial da concepção do tempo" (LE GOFF, 2012, p.201). Nessa perspectiva, o tempo pode ser definido 
como a sucessão do passado, do presente e do futuro. O tempo, então, pode ser objetivo, o tempo mensurável e subjetivo, que é o tempo regido pelas nossas sensações e sentimentos. O passado é reconstruído pela memória (essa reconstrução ocorre no presente) e o futuro é sonhado, planejado (esse planejamento acontece no presente). Só resta o presente, que é mutável, que é o devir (COMTE-SPONVILLE, 2006). Nesse sentido, a memória faz mover o tempo e habitar o espaço.

"Nós não possuímos uma única memória, mas várias" (DORTIER, 2010, p.393), pois a memória é algo forjado, construído, portanto ela é política, social e cultural. Nesse sentido, o contexto social é preponderante para a forma de seleção da memória, pois as lembranças/memória são reconstruções baseadas no passado, mas guiadas pelas necessidades e interesses do presente.

A apreensão da memória depende [...] do ambiente social e político: trata-se da aquisição de regras de retórica e também da posse de imagens e textos que falam do passado, em suma, de um certo modo de apropriação do tempo. As direções atuais da memória estão, pois, profundamente ligadas às novas técnicas de cálculo, de manipulação da informação, do uso de máquinas e instrumentos cada vez mais complexos (LE GOFF, 2012, p. 405).

O espaço escolar é o ambiente onde se ensina, se aprende e, também, um instrumento que pode ser modificado de acordo com a concepção de educação, representação sobre docência e intenção de formação do sujeito que se tem. Pode ser percebido como facilitador ou dificultador do trabalho do professor e, também, um fator de aprendizagem. "O espaço e os elementos que o configuram constituem, em si mesmo, recursos educativos e constam como tais do projeto de formação do professor(a)" (ZABALZA, 1998, p.237). Desta forma, em minha opinião, o espaço escolar contribui no estudo do conhecimento, da constituição e formação do sujeito, das relações sociais e até mesmo da construção de representações sobre o trabalho docente, pois ao mesmo tempo em que constrói essas representações, o espaço escolar é construído por elas, pois ele, em última análise, também é uma representação.

Considerando o cotidiano como uma dimensão do espaço, a escola como um fenômeno espacial e o professor como sendo construtor e sendo construído pelo espaço e pela experiência escolar, percebo que a escola é espaço físico e espaço subjetivo/memória. "É algo físico, material, mas também uma construção cultural" (VIÑAO-FRAGO, 2001, p.77). Desta forma, reflete e proclama 
discursos e interesses dominantes, além de materializar uma intenção de formação de futuros sujeitos (ESCOLANO, VIÑAO-FRAGO, 2001). É um espaço demarcado e mais ou menos permeável que configura uma pedagogia e uma racionalidade, um espaço que não é imparcial, que traz vestígios das relações sociais, símbolos, signos e linguagem, legitimando-se como elemento curricular, que forma alunos e professores.

As disposições temporais e espaciais regulam a conformação acadêmica e pautam coordenadas básicas de aprendizagem como pontualidade, organização, valores morais e culturais. Como o espaço escolar é um devir e sua percepção e construção depende das experiências passadas, dos valores e conceitos internos, o ambiente da escola se modifica a partir das memórias, crenças de seus atores e a partir da circulação das representações.

As representações inconscientes ou conscientes do que deve ser o espaço escolar podem levar a um funcionamento da organização da escola de forma que suas estruturas física, administrativa e social fiquem cristalizadas em uma mesma representação de "[...] uma maquinaria capaz de moldar subjetividades para algumas formas muito particulares de viver o espaço e o tempo" (VEIGA-NETO, 2003, p.107).

Os usos dos espaços escolares nos revelam as negociações ocorridas nesses espaços, seja de conflito, lutas pelos instrumentos de poder, tratamentos diferenciados, relações de exclusão, inclusão ou de forças que buscam sobrepor umas às outras. As práticas escolares e como se desenvolvem as relações de poder e saber são indícios de como o espaço é construído diariamente através dos valores e interesses estabelecidos anteriormente.

Os professores constroem/respondem ao espaço escolar de maneiras diferentes, influenciados pela cultura e experiências passadas, moldam seus valores baseados nas sensações que vão adquirindo através de seus órgãos dos sentidos, pelas emoções vivenciadas e pela articulação poder-saber. Ao mesmo tempo, os docentes reproduzem os espaços que viveram e que estão impregnados em suas lembranças. Se convidarmos professores a darem aulas em um espaço completamente flexível: biombos móveis no lugar das paredes; diversas opções de carteiras, cadeiras, mesas, sofás, divãs, almofadas; possibilidade de ter ou não quadro negro; ser ou não ser ao ar livre; disponibilidade de equipamentos 
audiovisuais; capacidade de regular a iluminação (cor e intensidade). O que aconteceria? Será que seria repetido o mesmo modelo de espaço a que estão acostumados? Será que conseguiriam pensar em um espaço diferente? Acredito que não, pois além do espaço físico, existe o espaço qualidade, das relações, didática, valores, a representação do que é um espaço escolar e as representações do trabalho docente. Mas, se um professor fizer a experiência de um novo espaço físico descobrirá uma nova forma de educação, novas relações de poder e saber? Penso que não completamente, pois a escola não será diferente somente pela mudança do professor ou do espaço, porque ainda estariam presentes estruturas e lógicas do sistema escolar, que também precisam ser modificadas para que a escola fique diferente.

Fruto de uma construção social, o arranjo espacial escolar é a manifestação concreta de encontros e desencontros dos grupos de interesses ao longo da história e é atravessado pelas concepções políticas presentes em dado momento, que através do discurso e das edificações erguem uma dimensão simbólica para uma nova representação, onde as ideias e noções sobre verdade ligam-se às práticas sociais que elas fundamentam. (LOPES, 2001, p.27)

Estamos em constante processo de absorção de sinais, símbolos e representações. O espaço que nos envolve e envolveu no passado exerce influência na criação da sociedade e, portanto, de outros espaços.

Pensando nas instalações escolares como representações, podemos observar que a repetição/reprodução é uma presença constante que transforma sala de aula em um espaço enfadonho, "estabelecendo uma perspectiva previsível e linear" (FRANÇA, 1994, p.71). A reprodução está dentro do contexto escolar. Não só do conteúdo e de sua memorização, mas também de seus espaços e da formação de hábitos. Essa reprodução e esses hábitos influenciam nas representações sociais do trabalho docente e no desprestígio da profissão de professor.

Entendendo esse caráter do espaço escolar de modificar e ser modificado, de Gerar e ser gerado pela coletividade e práticas, de construir e ser construído pelas representações, de formar e ser formado pelos sujeitos percebemos, segundo Santos, que "o espaço se dá ao conjunto dos homens que nele se exercem como um conjunto de virtualidades de valor desigual, cujo uso tem de ser disputado a cada instante, em função da força de cada qual.” (2008a, p.317)

O espaço não está baseado em valores e conceitos absolutos, mas sim em valores e conceitos que podem se modificar de acordo com o tempo, sociedade e 
cultura. Dessa forma, "o movimento do espaço, isto é, sua evolução [transformação], é ao mesmo tempo um efeito e uma condição do movimento de uma sociedade global" (SANTOS, 2008b, p.31). Há diversos espaços de acordo com a diversidade cultural e social. Nesse sentido, o espaço é produzido pelo homem, mas, "de fato, o espaço não é uma simples tela de fundo inerte e neutro" (SANTOS, 2008b, p.31). Ele articula a ordem social e tem função educativa, pois exerce um impacto direto sobre os sentidos e os sentimentos (TUAN, 1983). Está relacionado com a forma de utilização, ao tipo de atividade, à sua função, às circunstancias, às pessoas e às relações estabelecidas. Nessa perspectiva, o espaço é uma construção referenciada em elementos culturais, sociais e históricos. Não é só constituído de e pelos seres humanos e símbolos; as obras, relações, memórias, identidades e ações são, também, componentes importantes.

O espaço pode ser conceituado de três maneiras: a primeira, o espaço como produto de interrelações; a segunda, o espaço como possibilidade da existência da multiplicidade, da existência da pluralidade e, a terceira, o espaço está sempre sendo construído, nunca está terminado, portanto em permanente mudança (MASSEY, 2004). Nessa perspectiva, o espaço é lugar que se constitui na sua materialidade e é gerado pelas relações sociais. "O espaço, ele mesmo, é social" (SANTOS, 2008b, p.22), portanto histórico.

O uso humano de um espaço está ligado à memória, às vivencias passadas e ao simbolismo que esse espaço comunica. Nessa perspectiva, estudar a memória e o simbolismo é romper com a razão e pesquisar a experiência do homem no mundo. É utilizar a subjetividade como fontes de conhecimento.

Bachelard interrelaciona razão, imaginação e sonho, situando o ser humano no mundo a partir de sua dimensão imaginária e de seus devaneios. Nesse sentido, a imaginação destaca a relação entre o ser humano, seus devaneios e mundo. Essa relação surge das experiências situadas na esfera dos espaços e tempos íntimos, pois "todo espaço realmente habitado traz a essência da noção de casa" (BACHELARD, 2008, p.25). Ainda de acordo com esse autor, espaço e imagem estão associados à lembrança de um espaço vivido é uma imagem única e pessoal que fica guardada na memória e acaba por influenciar a percepção de outros espaços. A imagem é um signo comunicativo, uma visualidade dotada de valor e simbolismo. A visualidade delimita uma experiência cultural dinâmica. As 
lembranças, enquanto memórias, auxiliam a construção da percepção (BERGSON, 2010).

(...) Os espaços evocam recordações não apenas e necessariamente pelas associações provocadas pelo aspecto físico intrínseco à forma. Determinado espaço, também e simultaneamente, pode ser associado às lembranças de alguns acontecimentos que ocorreram na vida de determinado habitante, em certo tempo e lugar (RIBEIRO, 2003, p.68).

A percepção do espaço depende de certa forma da memória e da imaginação, pois a percepção está carregada de lembranças da memória, e as lembranças são fruto da percepção e da imaginação. Por exemplo,

um modelo específico de janela pode ter conotações diferentes de pessoa para pessoa, de acordo com o contexto cultural e, também, conforme as associações que elas estabelecem com suas próprias experiências passadas. (RIBEIRO, 2003, p.69)

Desta forma, cada pessoa percebe, atua e constrói diferentemente o mesmo espaço. Porém, temos órgãos dos sentidos comuns, portanto podemos esperar que essas percepções sejam parecidas principalmente se fizermos parte do mesmo grupo cultural, que cria uma memória coletiva sobre determinados espaços. Os estímulos captados pelos sentidos humanos são organizados e interpretados pelas percepções que atribuem significados, símbolos e valores ao espaço vivenciado. “A percepção é uma atividade, um estender-se para o mundo" (TUAN, 1980, p.14). Nesse sentido, as nossas crenças e vivências influenciam a forma como entendemos e vemos um espaço. Além disso, “[...] aquilo que se vê depende do lugar em que foi visto e das outras coisas que foram vistas ao mesmo tempo, pois as coisas existem em relação a outras e aos contextos em que estão inseridas" (RIBEIRO, 2003, p.98).

Possuímos imagens dos espaços vividos e essas imagens influenciam o modo como percebemos os espaços presentes. Essas imagens estão inscritas em contextos culturais, o que propicia diferentes leituras e representações. Nossa imaginação, memória individual e coletiva manipulam a imagem do espaço, processando valores (BACHELARD, 2008). Nesse sentido, existe uma relação entre os valores humanos dos espaços, os valores da intimidade do espaço e as representações desses espaços, pois o modo pelo qual se organiza a percepção humana, o meio em que ela se dá, é também condicionado historicamente.

Vivemos (...) em um espaço inteiramente carregado de qualidades, um espaço que talvez seja também povoado de fantasma; o espaço de nossa percepção primeira, o 
de nossos devaneios, o de nossas paixões possuem neles mesmos qualidades que são como intrínsecas. (FOUCAULT, 2009a, p.413)

Nessa perspectiva, se esses espaços são indeléveis, acompanha-nos durante toda a vida, constroem a nossa subjetividade e, por isso, influenciam na forma de vivenciar, construir e compreender os espaços. Além disso, socializar o olhar sobre o espaço e sua produção de subjetividades possibilita compreender as práticas visuais e espaciais que vão constituindo os sujeitos, percebendo aí formas de dominação, de passividade, de rotina, de vigilância, de saberes que constroem o ser professor e a forma de habitar e construir o espaço escolar.

\subsubsection{Cultura visual e espaço escolar: memórias e representações}

Não existe uma só definição do que é cultura visual, existem várias. De acordo com Hernadéz (2005), é interessante pensar a cultura visual como algo abrangente, como uma teia móvel, um emaranhado que tem mobilidade (fractais e rizomas), um campo de conhecimento que tem uma genealogia e que vai além da própria cultura visual, que perpassa e se utiliza de outros campos do saber, que é transdisciplinar. Por isso, as ideias da cultura visual podem ser de grande auxílio para o estudo do espaço escolar.

Quando analisamos um dado espaço, se nós cogitamos apenas dos seus elementos, da natureza desses elementos ou das possíveis classes desses elementos, não ultrapassamos o domínio da abstração. É somente a relação que existe entre as coisas que nos permite realmente conhecê-las e defini-las. Fatos isolados são abstrações e o que lhes dá concretude é a relação que mantêm entre si (SANTOS, 2012, p.25).

O espaço escolar, como dito anteriormente, é um instrumento de ensinoaprendizagem, pois pode ser construído pelas relações e transformado de acordo com a concepção de educação, representação sobre docência e intenção de formação do sujeito que se tem.

A Arquitetura não se reduz exclusivamente a uma questão de estilos e formas, nem é inteiramente determinada por condições sociológicas e econômicas. Ela tem vida própria, cresce ou definha, encontra novas potencialidades e as esquece novamente (GIEDION, 2004, p.49). 
Essa concepção de Arquitetura como um organismo em desenvolvimento é importante para o entendimento de como o espaço pode ser manipulado de acordo com a experiência espacial que se pretende, isto é, o espaço pode ser tratado como uma imagem, como obra visual habitável que permite diferentes e múltiplos modos de relacionamentos e relações. Além disso, existem vários modos de olhar. Esses modos são influenciados pela cultura, o que nos leva a entender que a visualidade é uma experiência do olhar e do pensar.

Tanto salas de aula quanto corredores, cantinas, estacionamentos, escadas, áreas de convivência e salas de professor expressam algo sobre a qualidade do projeto institucional. Basta que superemos nosso analfabetismo na leitura desses espaços, preenchendo seus vazios com indagações que permitam entrever o que sua arquitetura expõe e o que encobre (SORDI e MERLIN, 2007, p. 114).

Hernandéz (2003) aponta que estamos imersos em uma enxurrada de imagens e que ao lê-las compreendemos e damos sentidos ao mundo em que vivemos. Essa leitura das imagens é influenciada pelas representações visuais do passado e do presente (Hernadéz, 2005). Para Bergson (2010, p.30), "não há percepção que não esteja impregnada de lembranças. Aos dados imediatos e presentes de nossos sentidos misturamos milhares de detalhes de nossa experiência passada". Neste sentido, a memória é forma organizadora (BOSI, 2003).

As representações visuais constituem e são constituídas de posicionalidades, modos de significação e discursos. Por meio de atitudes, crenças e valores interagem com as formas de relação e jogos de poder. Neste sentido, é uma forma de subjetivação. É interessante ressaltar que nas representações visuais não é somente o visual e a estética que são utilizados, mas também a relação com outros códigos como a linguagem, o som, o gesto, o tato. As representações visuais criam significações e são capazes de transformar um objeto em imagem. Nesse sentido as imagens são construções culturais e dinâmicas, são representações sociais.

Mas como a cultura visual pode nos ajudar a interpretar as memórias dos professores sobre o espaço escolar? Além de fazer perceber o espaço como uma imagem/representação visual/social, a cultura visual nos dá pistas da construção e planejamento desse espaço e de como ele (espaço) está constantemente sendo 
planejado e construído para atender a determinadas proposições pedagógicas. Os museus podem servir de exemplo para isso.

O museu é um local de conexão entre o espaço, o tempo e a cultura. Ele carrega conceitos e discursos na forma de como distribuir e dividir o espaço, na estética, forma e tamanho. Utiliza-se da visualidade para transmitir mensagens e representações. Dessa forma, o museu acaba definindo o que é arte legítima, o que é para ser visto, em que ordem, de acordo com a intenção filosófica, pedagógica e política que se quer. Em outras palavras o museu administra a memória e a história (BRITTO, 2011). Para Hernandez (2003), o museu atua como espaços de consumo e, portanto, de produção de valores e produtos culturais diversificados em função dos diferentes tipos de públicos.

Podemos fazer a transposição dessas formas de arranjos dos museus para as escolas. As escolas trabalham com a visualidade desde sua fachada até a decoração e divisão interna. Desde os quadros de aviso até as relações professoraluno-gestão-família-funcionário. Transmitem mensagens e representações do que é educação. Tudo é organizado consciente ou inconscientemente de acordo com a formação de sujeito, intenções pedagógicas e educacionais, de acordo com as representações de escola, professor e aluno que se tem. Por isso, percebendo os espaços escolares vividos como imagens/representações visuais, o cotidiano como uma dimensão do espaço, a escola como um fenômeno espacial e o professor como sendo construtor e construído pelo espaço e pela experiência escolar, podemos falar que as memórias dos espaços escolares vividos pelos professores influenciam na sua forma de se constituir professor e na forma de compreender o que é escola.

\subsection{Instrumentos de investigação}

No meu entender o que há de pesquisador no professor não é uma qualidade ou uma forma de ser ou de atuar que se acrescente à de ensinar. Faz parte da natureza da prática docente a indagação, a busca, a pesquisa. (FREIRE, 1996, p.29) 
Neste item estão explicitados os instrumentos de investigação e, também, são apresentados os professores entrevistados.

A característica discursiva das ciências sociais possibilita a discussão da perspectiva macro x perspectiva micro. A macro e microteorização começam a declinar por seu caráter unilateral, que são insatisfatórias e geram contradições. Isso nos leva a pensar que devemos escolher nossas opções teórico-metodológicas de acordo com as necessidades da pesquisa e com que o campo e/ou o objeto de investigação 'indicam'. Nesse sentido, mesmo que a pesquisa seja realizada por meio de um microrrecorte do social, que ressalta individualidades específicas da pesquisa, será possível buscar o seu significado em uma dimensão mais ampla, buscando pontos de encontro que indiquem semelhanças entre as falas dos professores entrevistados e os professores em geral, definindo, a partir dessas semelhanças, possíveis generalizações (FONSECA, 1999).

A abordagem metodológica deste trabalho orienta-se para uma concepção que busca abranger os aspectos individuais e sociais do objeto e sujeitos investigados, por isso a escolha de fazer uma pesquisa de caráter qualitativo. Nessa perspectiva, não se trata de um estudo com proposta de amostragem e, sim, uma tentativa de registrar as memórias de espaços escolares vividos pelos professores entrevistados e a partir delas problematizar a forma de habitar o espaço escolar, pois "os indivíduos se valem de uma palavra singular, mas constituem entre si redes de sociabilidade" (DOSSE, 2009, p. 245).

A riqueza de significados do processo e dos resultados obtidos em uma pesquisa qualitativa depende diretamente e em grande medida da habilidade, disciplina e perspectiva do pesquisador - essa é a noção de reflexividade requerida para essa pesquisa, "em que a subjetividade do autor/pesquisador é assumida como componente essencial da análise" (FONSECA, 1999, p.61b).

Sou consciente que a pesquisa qualitativa traz princípios éticos que devem ser seguidos e desafios metodológicos, os quais, acredito, possam ser superados. Os desafios metodológicos a que me refiro são: a subjetividade dos dados e das interpretações que ao mesmo tempo são o ponto forte e fraco desse tipo de pesquisa. Ponto forte, pois a subjetividade faz com que cada pesquisa qualitativa seja única e significativa. Ponto fraco, pois os instrumentos de coletas geram dados que podem ser interpretados de diversas maneiras e a subjetividade do 
pesquisador influencia na coleta e na interpretação, pois a própria presença do pesquisador no campo pode modificar as relações sociais existentes no campo investigado e a postura de entrevistador pode gerar respostas que não condizem com o que o entrevistado pensa. Por isso, existe a necessidade de se analisar o não dito, o não explicito e de reconhecer que os valores e crenças do pesquisador afetam as interpretações e coletas dos dados e podem ser conflitantes com os valores e crenças dos habitantes do campo de pesquisa. Além disso, existe a necessidade de o pesquisador desenvolver uma atitude de estranhamento em relação ao objeto de pesquisa, principalmente no caso dessa pesquisa, pois frequento o espaço escolar, em diversos níveis desde os cinco anos de idade, muitas vezes como aluna e outras vezes como professora e pesquisadora.

A ideia desta pesquisa foi se conseguir um mergulho na memória do professor, para conhecer a sua vivência do espaço escolar enquanto aluno e entender como ele maneja o espaço como docente, conseguir um relato, uma narrativa de sua experiência no espaço escolar.

A internalização dos vínculos entre o pesquisador e o sujeito da pesquisa, pelo fato de suscitar uma palavra, de incitar alguém a narrar num relato de vida, pressupõe um contrato tácito no plano semiótico, no qual o pesquisador surge como remetente de um fazer-valer (falar) que o sujeito destinatário deverá retomar por conta própria como um querer-fazer (querer falar ou querer fazer saber) de ordem cognitiva pois não se trata de ação no sentido estrito (ordem pragmática) (DOSSE, 2009, p. 243).

Essas memórias estão repletas de imagens do espaço escolar vivido, o que possibilitou, de certa forma, perceber as experiências espaciais e experiências dos olhares sobre o espaço escolar: disciplinar, analítico, emocional. São memórias/relatos distintos - passado e presente -, mas que se complementam, entrecruzam e se significam, que evidenciam a subjetividade dos professores e de suas experiências no espaço escolar tanto como estudantes, quanto profissionais.

No momento em que a percepção social transita pela consciência individual, ela passa por uma triagem, é modelada e reelaborada, segundo os valores do entrevistado (subjetividade), reinscrevendo-se, ao mesmo tempo, no social, em virtude da situação de interação com o pesquisador e da experiência empírica de rememorar (BRANDÃO, 2010, p.49-50).

Nessa perspectiva, a entrevista foi utilizada como instrumento de coleta de dados, o que possibilitou captar os modos de pensar, sentir, situar-se e apreciar dos entrevistados em relação às questões-eixo e aos objetivos que orientaram esta 
pesquisa. A entrevista tornou-se uma narrativa de memória, um relato da dimensão vivida do espaço escolar para investigar a experiência de vivência desse espaço pelo professor tanto nas suas lembranças do tempo de aluno, quanto na sua experiência como docente.

"A narrativa é sempre uma escavação original do indivíduo, em tensão constante contra o tempo organizado pelo sistema. Esse tempo original e interior é a maior riqueza de que dispomos" (BOSI, 2003, p.66). A narrativa é um processo cultural, pois está sujeita ao narrador/entrevistado, suas vivências e valores, ao mesmo tempo em que depende do ouvinte/ pesquisador, suas análises e interpretações. Dessa forma, a entrevista como narrativa/relato de memória é um processo coletivo.

A recordação implica imaginação e composição, implica um certo sentido do que somos, implica habilidade narrativa. [...] Cada pessoa se encontra já imersa em estruturas narrativas que lhe pré-existem e em função das quais constrói e organiza de um modo particular sua experiência, impõe-lhe um significado. Por isso, a narrativa não é o lugar de irrupção da subjetividade, da experiência de si, mas a modalidade discursiva que estabelece tanto a posição do sujeito que fala (o narrador) quanto às regras de sua própria inserção no interior de uma trama (o personagem) (LARROSA, 1994, p.65-66).

As entrevistas foram individuais e semiestruturadas, com um roteiro (anexo p.109) que auxiliou o cumprimento das questões propostas na pesquisa, mas que ao mesmo tempo foi flexível. Essa flexibilidade permitiu adaptações, mudanças, abertura para diferentes depoimentos dos professores e que possibilitou captar tanto o lado profissional quanto o pessoal e a complementaridade desses aspectos na vivência e construção do espaço escolar. O local, dia e hora da entrevista foram sugeridos pelos entrevistados. A duração das entrevistas variou de acordo com o professor entrevistado, enquanto algumas entrevistas duraram aproximadamente três horas, outras foram realizadas em uma hora. É interessante ressaltar que a duração da entrevista não teve relação direta com o lugar onde foi realizada. Algumas entrevistas realizadas no ambiente de trabalho duraram mais tempo que outras realizadas fora desse ambiente.

Como a proposta desse estudo consiste em utilizar memórias de professores a partir das entrevistas, a análise das mesmas foi voltada para a compreensão das articulações entre passado e presente do uso e vivência do espaço escolar, não apenas para a compreensão linear dos conteúdos, mas também para um conjunto 
de fatores que constroem o contexto da entrevista, o dito e o não dito e a importância dada ao tema. Nesse sentido, a análise das entrevistas foi realizada após a transcrição ${ }^{11}$ integral das mesmas e constituiu na fragmentação do todo de cada entrevista em unidades de significado que posteriormente foram agrupadas em eixos de análise que foram divididos em memórias, práticas e a junção dos dois eixos. O primeiro (memória) trata das lembranças dos professores em seus tempos de aluno e suas formas de habitar o espaço escolar. O segundo eixo (práticas) traz as narrativas do presente, da forma de uso e construção do espaço da escola na docência. O terceiro eixo tenta perceber como as memórias dos espaços vividos no passado influenciam na construção e vivência do espaço presente. A divisão das entrevistas nesses temas de análise foi uma maneira mais prática de relacionar as falas dos informantes com os pressupostos teóricos e o problema da pesquisa e, dessa forma, atribuir sentido às informações coletadas.

Nos trechos das entrevistas transcritos nessa tese aparecem questões além das do espaço escolar como concepções de educação, de aluno, conceitos diversos que muitas vezes não serão discutidos, mas isso não quer dizer que não foram percebidos. Procuro fazer a escrita dessa tese o mais 'enxuta', por isso foco minhas análises no tema, questões e objetivos propostos no projeto de pesquisa e explicitados no item '1.1- Contornos da pesquisa'.

Tanto o espaço, quanto o trabalho docente, o ser professor, são construções sociais interdependentes, que são influenciadas pela trajetória de vida, cultura e formação do sujeito. Dessa forma, o esforço de análise do material coletado com as entrevistas foi o de compreender como as diferentes vivências dos professores do espaço escolar constroem suas práticas pedagógicas e suas representações de trabalho docente.

\subsubsection{Os atores da pesquisa}

Os sujeitos da pesquisa são professores de Ensino Superior e Ensino Médio, de instituições públicas e particulares. O grupo estudado pode parecer estranho e

\footnotetext{
${ }^{11}$ As transcrições das entrevistas foram realizadas no dia seguinte da realização das mesmas com total conformidade e identidade com a gravação.
} 
demasiadamente diverso, mas existem três razões que me levaram a escolher essa amostra. A primeira foi que os seis primeiros professores entrevistados têm experiência em ambas as áreas o que me levou a procurar profissionais que tivessem experiência em somente uma das áreas, pois gostaria de identificar se um professor que é somente de uma etapa de ensino constrói e compreende o espaço de forma diversificada. A segunda razão é que o Ensino Médio regular é propedêutico, por isso, é quase uma preparação para as provas que permitem o ingresso ao Ensino Superior. Já a terceira, é que a faixa etária dos alunos do Ensino Médio (15 a $17 \operatorname{anos}^{12}$ ) é razoavelmente próxima à faixa etária dos alunos de curso superior (18 a $24 \operatorname{anos}^{13}$ ). O público adolescente e de jovens adultos poderia ser um fator que 'induza' a determinada forma de manejar o espaço.

Além das razões citadas anteriormente, foi escolhido trabalhar com professores destas áreas de ensino, pois esses possuem uma vivência do espaço escolar diversificadas, além de serem importantes agentes na construção do espaço escolar. Escolher trabalhar com Ensino Superior e Médio proporciona uma reflexão abrangente das significações de espaço pelos professores, pois a significação do espaço decorre de sua inserção no sistema simbólico humano, fazendo com que o significado do espaço escolar não seja inerente a ele mesmo e sim, a situações, vivências e pessoas que nele habitam. Além disso, possibilita verificar diferentes disciplinas e como elas influenciam ou não na forma do professor ministrar aulas e administrar o espaço escolar, o que pode permitir maior reflexão do uso do espaço.

Foram escolhidos docentes de ambos os sexos e diferentes tempos de formação e docência. Como a profissão docente é uma construção histórica, as configurações do cotidiano do espaço escolar, do exercício da docência e do processo de construção e vivência do espaço escolar pelo professor são marcadas por diversas características de acordo com as experiências; tempo e espaço de atuação; formação e espaços frequentados pelo professor. Nesse sentido, a intenção de trabalhar com professores de Ensino Superior e Médio, com diferentes experiências é uma tentativa de capturar essas distintas configurações. Curiosamente, como trabalhamos com professores de diferentes formações,

\footnotetext{
${ }^{12}$ Faixa etária descrita não está levando em conta repetências.

${ }^{13}$ Faixa etária descrita não está levando em conta repetências ou ingresso tardio.
} 
alguns professores possuíam experiência profissional diversificada, pois atuavam em duas ou mais etapas de ensino: Ensino Superior, Ensino Fundamental, Ensino Médio, Ensino Técnico e cursos preparatórios para o vestibular.

A seleção dos entrevistados ocorreu por uma cadeia de relações: professores que são meus amigos pessoais indicavam professores conhecidos que após a entrevistas indicavam outros professores.
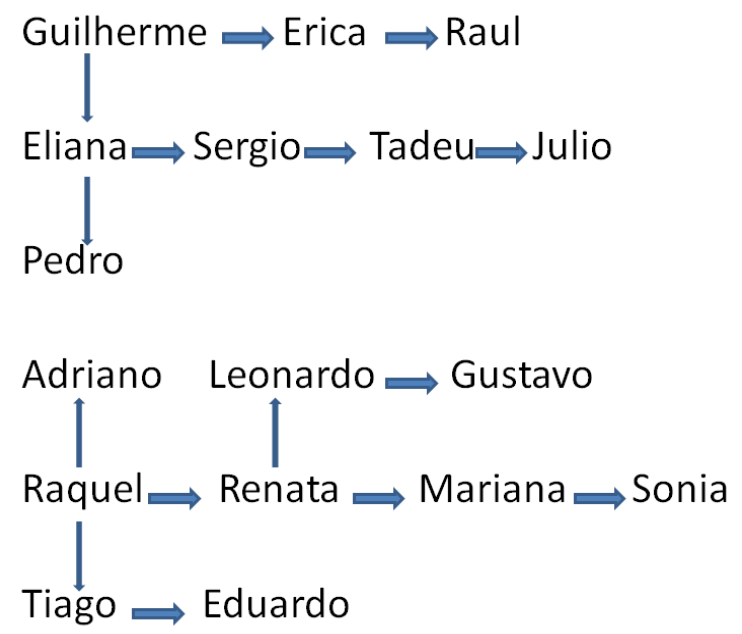

Imagem 1: Cadeia de relações (os nomes apresentados são fictícios) Fonte: Arquivo pessoal.

Ao todo foram entrevistados 17 (dezessete) professores: 6 (seis) do sexo feminino, 11 (onze) do sexo masculino, 9 (nove) do Ensino Superior e 8 (oito) do Ensino Médio, mas 6 (seis) desses professores tem experiência em ambas as áreas. $\mathrm{O}$ número de entrevistas não foi arbitrário, pois o critério essencial não foi o numérico, mas sim compreender as diferentes vivências do espaço escolar pelo professor. Como esta pesquisa foca professores de Ensino Médio e Ensino Superior de um município de Minas Gerais, fechou-se um ambiente social e cultural. Dessa forma, os depoimentos começaram a se repetir, indicando um esgotamento das respostas. Dessa forma, novas entrevistas não iriam oferecer ganho qualitativo adicional para a compreensão do fenômeno estudado (GASKELL, 2004).

Como os professores quem escolhiam o local das entrevistas, elas aconteceram em diversos lugares. Sete professores preferiram ser entrevistados em casa e dez no local de trabalho. Dessas dez, uma foi realizada na biblioteca, 
duas na sala da coordenação (pois os professores também exerciam o cargo de coordenador), três na sala dos professores, três na sala do departamento da disciplina e um na cantina da instituição de ensino onde o professor ministra aulas.

\section{Quadro I - Caracterização dos entrevistados}

\begin{tabular}{|c|c|c|c|c|c|}
\hline Nome & Idade & Disciplina & $\begin{array}{l}\text { Nível de ensino } \\
\text { em que atua }\end{array}$ & $\begin{array}{l}\text { Experiê } \\
\text { ncia em } \\
\text { ambas } \\
\text { as } \\
\text { áreas }\end{array}$ & Instituição atual \\
\hline Adriano $^{14}$ & 44 anos & Pedagogia & Ensino Superior & Sim & $\begin{array}{l}\text { Universidade } \\
\text { Pública }\end{array}$ \\
\hline Eduardo & 50 anos & Física & Ensino M édio & Sim & Escola Pública \\
\hline Eliana & 38 anos & Gastronomia & Ensino Superior & Não & $\begin{array}{l}\text { Universidade } \\
\text { Particular }\end{array}$ \\
\hline Erica & 37 anos & Biologia & Ensino Superior & Não & $\begin{array}{l}\text { Universidade } \\
\text { Particular }\end{array}$ \\
\hline Guilherme & 39 anos & Matemática & Ensino M édio & Sim & $\begin{array}{l}\text { Escola } \\
\text { Particular e } \\
\text { Escola Pública }\end{array}$ \\
\hline Gustavo & 40 anos & História & Ensino M édio & Sim & Escola Pública \\
\hline Julio & 34 anos & Administração & Ensino M édio & Não & $\begin{array}{l}\text { Universidade } \\
\text { Particular }\end{array}$ \\
\hline Leonardo & 41 anos & Geografia & Ensino M édio & Sim & Escola Pública \\
\hline Mariana & 37 anos & $\begin{array}{l}\text { Educação } \\
\text { Física }\end{array}$ & Ensino M édio & Sim & Escola Pública \\
\hline Pedro & 33 anos & Gastronomia & Ensino Superior & Não & $\begin{array}{l}\text { Universidade } \\
\text { Particular }\end{array}$ \\
\hline Raquel & 48 anos & Filosofia & Ensino M édio & Não & $\begin{array}{l}\text { Escola } \\
\text { Pública }\end{array}$ \\
\hline Raul & 40 anos & Arquitetura & Ensino Superior & Não & $\begin{array}{l}\text { Universidade } \\
\text { Particular }\end{array}$ \\
\hline Renata & 39 anos & Matemática & Ensino Médio & Não & $\begin{array}{l}\text { Escola } \\
\text { Pública }\end{array}$ \\
\hline Sérgio & 46 anos & Administração & Ensino Superior & Não & $\begin{array}{l}\text { Universidade } \\
\text { Particular }\end{array}$ \\
\hline Sonia & 26 anos & Física & Ensino M édio & Não & $\begin{array}{l}\text { Escola } \\
\text { Pública E Escola } \\
\text { Particular }\end{array}$ \\
\hline Tadeu & 51 anos & Gastronomia & Ensino Superior & Não & $\begin{array}{l}\text { Universidade } \\
\text { Particular }\end{array}$ \\
\hline Tiago & 52 anos & $\begin{array}{l}\text { Segurança do } \\
\text { Trabalho }\end{array}$ & Ensino Superior & Não & $\begin{array}{l}\text { Universidade } \\
\text { Pública }\end{array}$ \\
\hline
\end{tabular}

Fonte: Arquivo pessoal

\footnotetext{
${ }^{14}$ Todos os nomes dos entrevistados são fictícios.
} 


\section{Quadro II - Experiência profissional dos entrevistados}

\begin{tabular}{|c|c|c|}
\hline \multirow[t]{2}{*}{ Nome } & \multicolumn{2}{|c|}{ Formação } \\
\hline & Escolarização & Experiência Profissional \\
\hline Adriano & $\begin{array}{l}\text { Ensino Médio Regular. } \\
\text { Licenciatura e Bacharelado em } \\
\text { História, Especialização em } \\
\text { Sociologia Urbana, Especialização } \\
\text { em História das Relações } \\
\text { Internacionais, Mestrado em } \\
\text { Educação, Doutorado em } \\
\text { Educação, Pós Doutorado em } \\
\text { Cultura Visual e Educação. }\end{array}$ & $\begin{array}{l}\text { Trabalhou } 20 \text { anos com aula de } \\
\text { História para Ensino Fundamental } \\
\text { e M édio (escola particular e } \\
\text { pública). Trabalha há } 7 \text { anos na } \\
\text { pós-graduação em Educação, na } \\
\text { Graduação em Educação e História } \\
\text { em universidade pública. } \\
\text { Tempo de docência: } 21 \text { anos. }\end{array}$ \\
\hline Eduardo & $\begin{array}{l}\text { Ensino M édio com Curso técnico } \\
\text { em Química. } \\
\text { Licenciatura em Física, Mestrado } \\
\text { em Física, Doutorado em Educação } \\
\text { e Ciências. }\end{array}$ & $\begin{array}{l}\text { Trabalhou com Graduação em } \\
\text { Física em universidades } \\
\text { particulares. Trabalhou como } \\
\text { professor de EJA e Ensino M édio } \\
\text { noturno em escola pública. } \\
\text { Trabalha como professor de Física } \\
\text { no Ensino M édio em escola } \\
\text { pública. } \\
\text { Tempo de docência: } 20 \text { anos. }\end{array}$ \\
\hline Eliana & $\begin{array}{l}\text { Curso Normal. } \\
\text { Graduada em Pedagogia e } \\
\text { Gastronomia. }\end{array}$ & $\begin{array}{l}\text { Trabalhou com curso técnico em } \\
\text { escola particular. Trabalha na } \\
\text { graduação em Gastronomia em } \\
\text { universidade particular. } \\
\text { Tempo de docência: } \mathbf{1 5} \text { anos. }\end{array}$ \\
\hline Erica & $\begin{array}{l}\text { Ensino Médio Regular. } \\
\text { Licenciatura em Ciências } \\
\text { Biológicas, Mestrado em Ciências } \\
\text { Biológicas. }\end{array}$ & $\begin{array}{l}\text { Trabalha na Graduação em } \\
\text { Medicina Veterinária, Nutrição, } \\
\text { Biomedicina e Ciências Biológicas } \\
\text { em universidades particulares. } \\
\text { Tempo de docência: } 10 \text { anos. }\end{array}$ \\
\hline Guilherme & $\begin{array}{l}\text { Ensino Médio Regular } \\
\text { Licenciatura em Matemática, } \\
\text { Especialização em Matemática, } \\
\text { Mestrando em Educação } \\
\text { Matemática (fez um mestrado em } \\
\text { educação, mas não conseguiu o } \\
\text { certificado, pois o curso não foi } \\
\text { reconhecido pelo MEC). }\end{array}$ & $\begin{array}{l}\text { Trabalhou na graduação em } \\
\text { Ciências Biológicas, Geografia e } \\
\text { Matemática em universidade } \\
\text { particular. Trabalha com Ensino } \\
\text { Fundamental e M édio em escola } \\
\text { pública e particular. } \\
\text { Tempo de docência: } 19 \text { anos. }\end{array}$ \\
\hline Gustavo & $\begin{array}{l}\text { Ensino Médio Regular. } \\
\text { Licenciado em História; Mestrado } \\
\text { e Doutorado em História } \\
\text { Econômica. }\end{array}$ & $\begin{array}{l}\text { Trabalhou na graduação em } \\
\text { História em universidades públicas } \\
\text { e particulares. Trabalha com } \\
\text { Ensino Fundamental e M édio em } \\
\text { escola pública. } \\
\text { Tempo de docência: } \mathbf{1 6} \text { anos. }\end{array}$ \\
\hline Julio & \begin{tabular}{ll}
\multicolumn{2}{l}{ Ensino Médio Regular. } \\
Bacharel em & Turismo; \\
Especialização em & Gestão \\
Empresarial e Hotelaria. &
\end{tabular} & $\begin{array}{l}\text { Trabalha na graduação em } \\
\text { Gastronomia e Economia em } \\
\text { universidades particulares. } \\
\text { Tempo de docência: } 3 \text { anos. }\end{array}$ \\
\hline
\end{tabular}




\begin{tabular}{|c|c|c|}
\hline Leonardo & $\begin{array}{l}\text { Ensino M édio Regular. } \\
\text { Licenciatura em Geografia; } \\
\text { Mestrado em Planejamento } \\
\text { Urbano. }\end{array}$ & $\begin{array}{l}\text { Trabalhou em Cursinho pré- } \\
\text { vestibular; Ensino M édio (escola } \\
\text { particular e pública). Atualmente } \\
\text { trabalha no Ensino M édio - escola } \\
\text { pública. } \\
\text { Tempo de docência: } 14 \text { anos. }\end{array}$ \\
\hline Mariana & $\begin{array}{l}\text { Ensino Médio com Curso técnico } \\
\text { em Química. } \\
\text { Graduação em Educação Física, } \\
\text { Especialização, Mestrado e } \\
\text { Doutorado em Educação Física. }\end{array}$ & $\begin{array}{l}\text { Trabalhou na Graduação em } \\
\text { Educação Física em universidades } \\
\text { particulares. Trabalha no Ensino } \\
\text { Fundamental e M édio em escola } \\
\text { pública. } \\
\text { Tempo de docência: } \mathbf{1 3} \text { anos. }\end{array}$ \\
\hline Pedro & $\begin{array}{l}\text { Ensino Médio Regular. } \\
\text { Bacharel em } \quad \text { Turismo; } \\
\text { Especialização em Hotelaria. }\end{array}$ & $\begin{array}{l}\text { Trabalha na Graduação em } \\
\text { Gastronomia em universidade } \\
\text { particular. } \\
\text { Tempo de docência: } \mathbf{3} \text { anos. }\end{array}$ \\
\hline Raquel & $\begin{array}{l}\text { Ensino Médio com Curso Técnico } \\
\text { em Edificações. } \\
\text { Bacharel em Direito, Licenciatura e } \\
\text { Bacharelado em Filosofia; } \\
\text { Mestrado em } \quad \text { Educação; } \\
\text { Doutoranda em Educação. Curso } \\
\text { Técnico em Informática. }\end{array}$ & $\begin{array}{l}\text { Trabalhou com curso técnico em } \\
\text { Instituto Federal. Trabalha como } \\
\text { professora de Filosofia em Ensino } \\
\text { Médio em escola pública. } \\
\text { Tempo de docência: } 25 \text { anos. }\end{array}$ \\
\hline Raul & \begin{tabular}{llr}
\multicolumn{3}{l}{ Ensino Médio Regular. } \\
Bacharel em Arquitetura e \\
Urbanismo; Especialização em \\
Engenharia de Segurança do \\
Trabalho, Mestrado \\
Engenharia.
\end{tabular} & $\begin{array}{l}\text { Trabalhou } 4 \text { anos como professor } \\
\text { substituto na Graduação em } \\
\text { Arquitetura em universidade } \\
\text { pública. Trabalha na graduação em } \\
\text { Design em universidade particular. } \\
\text { Tempo de docência: } 5 \text { anos. }\end{array}$ \\
\hline Renata & $\begin{array}{l}\text { Ensino M édio Regular. } \\
\text { Licenciatura em Matemática; } \\
\text { Especialização em Gestão em } \\
\text { Educação a Distância; Mestrado e } \\
\text { Doutorado em Educação. }\end{array}$ & $\begin{array}{l}\text { Foi tutora de educação à distância } \\
\text { na Graduação em pedagogia. } \\
\text { Trabalha com Ensino Fundamental } \\
\text { e Médio em escola pública (já } \\
\text { trabalhou em mais de uma escola } \\
\text { pública. Atualmente só leciona em } \\
\text { uma escola). } \\
\text { Tempo de docência: } \mathbf{1 5} \text { anos. }\end{array}$ \\
\hline Sérgio & $\begin{array}{l}\text { Ensino M édio Regular. } \\
\text { Bacharel em Administração; } \\
\text { Especialização em Marketing e } \\
\text { Mestrado em Responsabilidade } \\
\text { Social. }\end{array}$ & $\begin{array}{l}\text { Trabalha na Graduação em } \\
\text { Administração, Engenharia de } \\
\text { Produção, Jornalismo e } \\
\text { Gastronomia em universidades } \\
\text { particulares. } \\
\text { Tempo de docência: } 10 \text { anos. }\end{array}$ \\
\hline Sonia & $\begin{array}{l}\text { Ensino Médio Regular. } \\
\text { Licenciatura em Física. Quer tentar } \\
\text { fazer M estrado em Física. }\end{array}$ & $\begin{array}{l}\text { Foi professora particular de } \\
\text { matemática e física. Trabalha } \\
\text { como professora de Física no } \\
\text { Ensino Médio em escola pública e }\end{array}$ \\
\hline
\end{tabular}




\begin{tabular}{|c|c|c|}
\hline & & $\begin{array}{l}\text { particular e em cursinho Pré } \\
\text { vestibular. } \\
\text { Tempo de docência: } 6 \text { anos. }\end{array}$ \\
\hline Tadeu & $\begin{array}{l}\text { Ensino M édio Regular. } \\
\text { Bacharel em Administração, } \\
\text { Especialização em Hotelaria e em } \\
\text { Programa de Gestão de Negócios } \\
\text { Gastronômicos. }\end{array}$ & $\begin{array}{l}\text { Trabalhou com graduação em } \\
\text { Administração e Ciências } \\
\text { Contábeis em universidades } \\
\text { particulares. Trabalha com } \\
\text { Graduação em Gastronomia em } \\
\text { universidade particular. } \\
\text { Tempo de docência: } \mathbf{1 5} \text { anos. }\end{array}$ \\
\hline Tiago & $\begin{array}{l}\text { Ensino Médio Regular. } \\
\text { Bacharel em Ciências Contábeis e } \\
\text { em Direito. Curso técnico de } \\
\text { Segurança do trabalho. }\end{array}$ & $\begin{array}{l}\text { Trabalha com curso técnico e na } \\
\text { graduação em Engenharia } \\
\text { Mecatrônica em instituto federal. } \\
\text { Tempo de docência: } 20 \text { anos. }\end{array}$ \\
\hline
\end{tabular}

Fonte: Arquivo pessoal. 


\section{Espaços e tempos de aluno: memórias dos professores}

Possuo tanto melhor o mundo quanto mais hábil for em miniaturizá-lo. Mas, fazendo isso, é preciso compreender que na miniatura os valores se condensam e se enriquecem (BACHELARD, 2008, p.159).

Neste capítulo trago as memórias de vivência do espaço escolar dos professores no período em que eram estudantes. A partir delas tento perceber as representações e construções espaciais dessa época de vida dos docentes entrevistados.

Como a profissão docente é uma construção histórica e social e o se tornar professor é um processo de construção que acontece durante a formação acadêmica e durante o exercício da docência, o processo de habitar o espaço escolar tanto como aluno, quanto como profissional marca essa formação e participa do processo de subjetivação e de representação do que é 'ser professor' e do que é o espaço escolar. Pessoas de cultura, formação e experiências diferentes habitam mundos sensoriais diferentes.

Uma triagem seletiva de dados sensoriais admite alguns dados e exclui outros, de tal modo que a experiência como é percebida através de um conjunto de filtros sensoriais determinados pela cultura é totalmente diferente da experiência percebida através de outro conjunto. (HALL, 2005, p. 3)

As memórias e relatos dos professores são narrativas imagéticas que trazem o passado e o presente, se complementam, se entrecruzam e se significam. Evidenciam a subjetividade dos professores e as suas experiências no espaço escolar tanto como estudantes, quanto profissionais.

A memória [...] permite a relação do corpo presente com o passado e, ao mesmo tempo, interfere no curso atual das representações. [...] Aparece como força subjetiva ao mesmo tempo profunda e ativa, latente e penetrante, oculta e invasora. (BOSI, 2003, p.36)

A narrativa é um processo cultural, pois está sujeita ao narrador/entrevistado, suas vivências e valores, ao mesmo tempo em que depende do ouvinte/ pesquisador, suas análises e interpretações.

As memórias de um tempo e espaço vividos pelos professores entrevistados formam uma narrativa do espaço vivido que se entrelaça na forma de vivenciá-lo 
no presente o que cria diferentes significados na forma de exercer sua atividade docente.

Neste capítulo, tratamos das memórias dos professores enquanto aluno, de suas lembranças afetivas do que é ou era escola. Essas memórias partilhadas nas entrevistas construíram uma narrativa que conta um pouco do que é ser aluno, pois nenhuma vida é uma trajetória isolada, está imersa em uma teia de relações sociais (LELIS, 2001).

\subsection{Memórias que se intercruzam}

Para Bergson (2010, p. 5), “a lembrança [...] representa precisamente o ponto de interseção entre o espírito e a matéria”, dessa forma, a memória participa da narrativa dos indivíduos e dos grupos, ordena o pensamento e a reflexão, propicia novas ideias. Essa característica faz da memória um fenômeno tanto individual e psicológico, quanto coletivo e social. Nesse sentido, as memórias individuais dos professores entrevistados se intercruzam com a coletiva, pois todos eles, mesmo de gerações diferentes, relataram ter estudado em contextos de práticas de ensino tradicionais.

As aulas eram assim, de forma metódica mesmo, estilo quadro e giz, os professores sempre avaliavam através de provas $e$ trabalhos [...]. (Sônia, 29 anos, professora do Ensino Médio)

Era uma disposição tradicional que se mantém até hoje em formato de auditório, o professor na frente em um nível elevado numa plataforma, mesa de professor, cadeira de professor, quadro verde, giz, cadeiras posicionadas na vertical em colunas e é uma aula clássica, o professor fala e a participação, que eu lembre, era menos do que hoje em dia. A gente escutava muito, obedecia muito e fazia o que tinha que ser feito. (Tadeu, 51 anos, professor do Ensino Superior)

O contexto era tradicional [...]. (Leonardo, 41 anos, professor do Ensino Médio).

Era uma escola tradicional que minha mãe tinha estudado, meus parentes todos tinham estudado e por ser uma escola tradicional era um prédio, uma característica assim, tinha uma parte antiga que era a parte da entrada que era um bloco que devia ter ali um bloco de umas quatro salas, bem antigo, um 
prédio antigo, daquele modelo antigo de pé direito alto, salas amplas, igual a essas casas de cidade do interior, tinha janela de madeira e aí tinha um pátio com uma quadra e foi construído um outro bloco de salas com uma arquitetura completamente distinta, mas esse processo ele foi feito ao longo da minha trajetória do Ensino Fundamental. Nesse prédio novo a disposição das carteiras era a mesma das salas do prédio antigo, mas o pé direito não era alto, as já nelas não eram de madeira..." (Adriano, 44 anos, professor do Ensino Superior)

Então assim, a escola era muito tradicional, mas não quer dizer que ela não era prazerosa. (Renata, 39 anos, professora do Ensino Médio)

Era uma sala de aula bem tradicional, tá. Na época nem existia tantos recursos audiovisuais didáticos, era muito quadro negro e exercício. Normalmente aula, quadro negro, material... (Pedro, 33 anos, professor de Ensino Superior)

E era uma [carteira] atrás da outra. Era aquilo... a sala de aula e o quadro negro. Era sempre aquilo. O máximo que acontecia era a gente se posicionar de formas diferentes no sentido: vou ler um texto, tinha que levantar para ler o texto. (Raquel, 48 anos, professora do Ensino Médio)

Analisando as falas acima, percebemos que, a maioria descreve a escola que frequentaram como 'tradicionais', isto é, como algo que não se modificou com o passar dos tempos, como se a educação e o espaço escolar estivessem cristalizados ao costumeiro, fundamentada em ações baseadas em uma tradição enraizada. Os que não falam em contexto tradicional, descrevem o espaço da sala de aula como algo quase imutável: carteiras enfileiradas, ou então falam sobre o estilo de aula expositiva - quadro e giz. Dois depoimentos se destacam. O de Adriano, que confirma o enraizamento da cultura de salas de aulas com carteiras enfileiradas, pois em sua escola do Ensino Fundamental foi construído outro prédio, específico para abrigar parte dos alunos, mas ao invés de ocorrer alguma mudança, foram implantadas salas que repetiam a mesma disposição de carteiras enfileiradas em frente ao quadro negro. O outro depoimento que se diferencia é o da professora Renata, que descreve um contexto tradicional, mas que era prazeroso. Dessa forma, Renata quebra, mesmo que inconscientemente, com o paradigma do contexto tradicional puro e indiferenciado do espaço escolar, pois ela conseguia perceber outras nuances além do espaço físico.

Os professores entrevistados entendem como contexto de educação tradicional, a forma de ensino em que o professor fala e o aluno escuta, isto é a 
aula expositiva em que é usado o quadro e o giz. Apontam poucas diferenças entre as práticas pedagógicas atuais das antigas e também não as distinguem nas diferentes etapas de ensino. Quando apontam diferenças, não sabem especificálas.

Dos entrevistados muitos ${ }^{15}$ não se considerem professores com práticas tradicionais. Os que se consideram trabalhando em contexto de práticas tradicionais falam que isso ocorre não por causa da formação, mas por imposições externas às suas vontades ${ }^{16}$.

"Uma memória coletiva se desenvolve a partir de laços de convivência familiares, escolares, profissionais. Ela entretém a memória de seus membros, que acrescenta, unifica, diferencia, corrige e passa a limpo" (BOSI, 1994, p. 408-11). Talvez essa percepção de terem estudado em contexto de educação tradicional ocorra porque a memória coletiva tende a idealizar o passado e simplificar a noção de tempo, pois ela é baseada em imagens. A imagem que temos de escola, a representação que temos de como ensinar é: professor falando, aluno escutando. Pensem nos filmes, nos desenhos animados, livros, a maioria retrada a escola dessa forma. Se vasculharmos as nossas memórias a procura de imagens sobre a escola, as primeiras que apareceram serão a de uma sala de aula onde o professor está à frente explicando e os alunos estão sentados e ouvindo. Possivelmente essas memórias se intercruzem porque essas são lembranças fortemente construídas na infância, onde o lendário invade o espaço da memória e indica que as crianças não só criam fantasias, como também as vivem.

Não é com essas fábulas fósseis, esses fósseis de fábulas, que vive a criança. É nas suas próprias falas. É no seu próprio devaneio que a criança encontra as fábulas [...] então, a fábula é a própria vida. (BACHELARD, 1988, p.113)

[...] Devemos lembrar também que na maioria das memórias existem marcos ou pontos relativamente invariantes, imutáveis. [...] Quais são, portanto, os elementos constitutivos da memória individual ou coletiva? Em primeiro lugar são os acontecimentos vividos pessoalmente. Em segundo lugar, são os acontecimentos que eu chamaria de "vividos por tabela", ou seja, acontecimentos vividos pelo grupo ou pela coletividade à qual a pessoa se sente pertencer. São acontecimentos dos quais a pessoa nem sempre participou, mas que, no imaginário, tomaram tamanho relevo que, no fim das contas, é quase impossível que ela consiga saber se participou ou não. Se formos mais longe, a esses acontecimentos vividos por tabela vêm se juntar todos os eventos que não se situam dentro do espaço-tempo de uma

15 Doze professores em um total de dezessete não se consideram professores com práticas tradicionais.

${ }^{16}$ Essas imposições serão discutidas nos itens 5.3 e 5.4 do capítulo 5. 
pessoa ou de um grupo. É perfeitamente possível que, por meio da socialização política, ou da socialização histórica, ocorra um fenômeno de projeção ou de identificação com determinado passado, tão forte que podemos falar numa memória quase que herdada (POLLAK, 1992, p.201).

Outra forma de explicar esse fenômeno é a circulação do discurso. Discurso, para Foucault (2007; 2008b, 2008c), é um conjunto de enunciados que se apoia em um mesmo sistema de formação e obedece a regras de funcionamento comuns, que tem uma função normativa e reguladora. Dessa forma, o discurso coloca em funcionamento mecanismos de organização da escola por meio da produção de saberes, estratégias e práticas. Neste caso, da construção do discurso das práticas tradicionais de ensino, o que interessa não é a autonomia desse discurso ou da memória coletiva, mas sim as estratégias de poder que marcam esse discurso, que é somente um dos planos de discursos sobre a escola que causa certa miopia para pequenas mudanças do espaço escolar, tanto fisicamente (mobiliário escolar), quanto nas relações (relação professor-aluno e família) e símbolos (religiosos, sociais, políticos).

\subsection{Sabores e cheiros, Afeto, carinhos, desconfortos: espaços afetivos}

As lembranças que os professores narraram sobre a escola estão carregadas de emoção e de certa nostalgia. O carinho que eles demonstram por esses momentos, a voz doce e suave, o brilho nos olhos demonstram o quanto essas experiências os tocaram.

As influências sociais, econômicas e funcionais desempenham um papel vital em todas as atividades humanas, das ciências às artes. Mas existem ainda outros fatores que devem ser levados em consideração- nossos sentimentos e emoções. Apesar de comumente descartados como triviais, o efeito que esses fatores exercem sobre as ações dos homens é imenso (GIEDION, 2004, p.459).

A escola tinha um pátio. É... que era onde a gente ficava na hora do recreio e na hora do início da aula que a gente tinha que fazer fila. Aí, aquela fila era muito interessante, porque a gente chegava, se posicionava por ordem de tamanho.[...] $E$ todo mundo com as merendeiras, a gente sentia o cheiro das merendas, sabe? Era legal. Aquilo marcava. Não sei. Aquele cheiro daquelas merendas. [...] Hoje, quando alguém faz limonada... limonada mesmo. Eu sinto o cheiro de lá, daquele lugar, sabe? Era o lugar onde a gente ficava em fila. A gente 
fazia uma oração e cantava o hino nacional. Aí ia para a sala de aula. [...]

E a gente tinha direito a merenda. Também é outro momento que eu amava e aquilo me subjetivou, me marcou, porque até hoje eu gosto de doce quente. Por quê? Porque a nossa merenda era ou canjica, ou arroz doce, ou doce de abóbora! Mas sempre quentinho. Então até hoje eu como doce quente. Se for fazer doce, este tipo de doce, eu só como ele quentinho. Eu esquento meu arroz doce no micro-ondas para comer. Eu não como gelado. Raramente. Não é que eu não como. Raramente. Então assim, isso marca lá, isso é marca lá, que eu não tenho como comer um arroz doce e não lembrar daquele espaço, daquele local, daquela situação que a gente vivia. E era tipo um galpão com bancos e mesas. (Raquel, 48 anos, professora do Ensino Médio)

E depois o polivalente não tinha mais isso [castigos física palmatória], era um lugar onde havia professores novos com a prática pedagógica já diferente, muito carinhosos, então pra mim foi muito bom tanto que eu fiz questão... Eu conversei com a minha mãe e eu quis: 'Eu quero estudar nessa escola polivalente' que era mais longe da minha casa, eu caminhava uns 3 quilômetros que era quase o dobro da distância que era antes o outro colégio (Eduardo, 50 anos, professor do Ensino Médio)

"Cada lugar se define tanto por sua existência corpórea, quanto por sua existência relacional" (SANTOS, 2008b, p.159). As falas de Raquel e Eduardo trazem uma carga de afetividade muito grande. Essa afetividade demonstra que o espaço escolar vivenciado, experienciado, realmente habitado torna-se dotado de valor e identidade.

"Não esqueçamos que a memória parte do presente, de um presente ávido pelo passado, cuja percepção é a apropriação veemente do que nós sabemos que não nos permite mais" (BOSI, 2003, p.20).

$\mathrm{O}$ afeto que se tem de um lugar está ligado à experiência que se pode ter nesse espaço. De acordo com Tuan (1983, p.11), “a experiência é construída de sentimentos e pensamento". Ainda de acordo com esse autor, experienciar um espaço é aprender. Significa atuar sobre esse espaço e criar a partir dele, desenvolver afetividade ou sentimentos por ele e, dessa forma, conseguir uma real experiência espacial.

Então tinha uma questão muito legal da escola que marcava a gente que era todo início do ano a gente ficava ansioso pra saber que novidade que tinha na escola, na construção da 
escola. Então, por exemplo, a escola tinha um processo que eu achava super legal, que eu não vejo em nenhuma outra escola. Todo ano a escola se pintava, então se acabava o ano a escola tava azul, você voltava no outro ano... Eu lembro que a criançada, a gente ficava buscando o que tinha mudado. A primeira coisa que a gente via que mudou era a cor da sala. Todas as salas mudavam a cor. A escola inteira se pintava. Até as salas que se mantinham na mesma cor, você via que a pintura tava nova e ao mesmo tempo iam construindo. Então essa área que foi construída, eu lembro que tinha uma casinha que era embaixo da árvore que era uma frente de cantina e em um ano isso sumiu, porque foi construído um prédio nas férias e a cantina passou a ser incorporada como parte do prédio. Então era uma coisa super pequenininha, rústica, que eu adorava e perdeu completamente a característica, ela sumiu, desapareceu. Ela foi demolida pra construir o prédio. E aí esse prédio, eu lembro que na $3^{a}$ série eu estudei nesse prédio novo $\underline{e}$ era uma sala que batia sol a tarde inteira, então era um calor insuportável, a sala era horrível e não era ampla igual aos outros prédios, não tinha o pé direito alto, isso tudo abafava, colocaram umas cortinas pra tentar abaixar o sol, então fechava as cortinas, acendia a luz, era uma sauna e tinha toda a questão de ter que prestar atenção que era a Dona Carmênia e ela gritava e era o incômodo do espaço, a gente nem podia perceber ele por conta da rigidez das disciplinas. (Adriano, 44 anos, professor do Ensino Superior)

A fala de Adriano demonstra quanto o espaço pode ser a materialização da experiência da vivencia escolar, criar elos afetivos e gerar emoções entre o sujeito e a escola: as surpresas das mudanças no espaço físico ocorridas durante as férias, desaparecimento da cantina rústica, desconforto físico e emocional na sala de aula. Dessa forma, "o sentido que o ser humano tem do espaço apresenta uma relação muito próxima com seu sentido do eu, que está em íntima interação com o ambiente" (HALL, 2005, p.77). O ser humano possui aspectos visuais, cinestésicos, táteis e térmicos que o desenvolvimento pode ser estimulado ou inibido pelo ambiente (TUAN, 1980, 1983). A partir dessas experiências as pessoas percebem, conhecem e constroem suas espacialidades utilizando suas emoções e seus sentidos.

[...] foi suspenso por jogar dama durante o horário da aula, em frente à escola] E porque tava com a turma do mal também, aí eu acho que era mais pros outros que já tinham aprontado várias vezes e como eu tava no bolo, mas eu era o certinho. E aí eu fiquei chocado com aquilo assim, três dias só porque eu tava jogando dama, tava aprendendo a jogar dama [...]. Eu fui pra casa e houve uma falha lá e eles não contaram pra minha mãe. Eu fui pra casa e todo dia eu saia de casa e ia pra escola, não contei que eu tava suspenso, eu saia de casa ia pra escola e 
ia pra biblioteca da cidade ou ia andar pela cidade, passear pela cidade, caminhar pela cidade. Acabei gostando daquilo sabe, aí no $4^{\circ}$ dia eu 'Ah tá! Nunca mais vão me suspender lá, porque não vão me ter lá, eu nunca mais vou voltar praquele lugar. Já que eles não me querem... Ficar 3, 4, 5, nunca mais eu voltar praquela escola'. Sabe como criança é fantasiosa, então foi o $4^{\circ}$ dia, o $5^{\circ}$ dia, o $6^{\circ}$ dia e eu fazia a mesma coisa, eu caminhava pelo centro da cidade, parava na banca lia uma história em quadrinho, passava o tempo e quando eu via, tinha passado o tempo e eu voltava pra casa, aí um dia essa professora querida veio na minha casa e falou com a minha mãe. Aí que minha mãe descobriu que eu não tava indo pra escola, que o período de suspensão tinha acabado. Eu me lembro assim, é engraçado, mas ao mesmo tempo fico envergonhado. [...] É, ela [professora querida] me pediu pra voltar. 'Já que a senhora tá pedindo eu volto'. Foi uma história muito legal essa história de a professora ir na casa, sabe? Se fosse aqui no colégio, eu mandaria uma carta, um recurso. Mas não tinha telefone, essas coisas não existiam. Então foi na tua casa, isso foi muito legal. Essa professora foi muito querida mesmo, muito querida, e ela assim... Eu lembro que ela uma vez, ela era muito esperta, ela trouxe um jogo de xadrez, ela disse que tinha ganhado aquilo, mas que não sabia jogar. Hoje eu penso, foi golpe dela, ela sabia jogar... 'Então nós vamos ler' [as regras do jogol. Aí paramos a aula e ficamos lendo o jogo de xadrez lá, foi depois daquela história da dama [da suspensão por jogar Damasl, bem depois é, eu... Talvez ela conectasse, mas eu não conectei uma coisa com a outra, me pegou de surpresa [...]. Então esses afetos que esses professores montavam... Isso foi excepcional para a minha formação. (Eduardo, 50 anos, professor do Ensino Médio)

As ações de resgate do aluno que a professora de Eduardo elaborou, foi de extrema importância para formação dele, mas também para a criação de vínculos e vivência do espaço escolar.

$\mathrm{O}$ que começa como espaço indiferenciado transforma-se em lugar à medida que conhecemos melhor e dotamos de valor [...] As ideias de "espaço" e "lugar" não podem ser definidas uma sem a outra. A partir da segurança e estabilidade do lugar estamos cientes da amplidão, da liberdade e da ameaça do espaço e vice-versa. Além disso, se pensarmos no espaço como movimento, então lugar é pausa; cada pausa no movimento torna possível que localização se transforme em lugar (TUAN, 1983, p.6).

A afetividade exerce um fator importante nas relações humanas, inclusive na relação professor-aluno. Vigotski (2001) argumenta que as emoções influenciam nosso modo de agir, inclusive nossa aprendizagem. A atitude da 'professora querida' reestabeleceu a relação de confiança e pertencimento ao espaço escolar que havia sido interrompida pela punição dada ao aluno (professor 
entrevistado) e isso, como ele mesmo falou, isso foi excepcional para a sua formação. "O recordar [...] é um tempo sabático e cada fato bruto é lapidado pelo espírito até que desprenda luz" (BOSI, 2003, p. 34).

\subsection{Espaços de alívio: heterotopias}

"Em geral, a heterotopia tem como regra justapor em um lugar real vários espaços que, normalmente, seriam ou deveriam ser incompatíveis" (FOUCAULT, 2013, p.24).

Nas falas dos professores, identificamos três espaços que trazem um sentido de heterotopia, espaços reais, mas que carregam uma simbologia de calma e tranquilidade: as áreas verdes, a quadra de esportes e a biblioteca. Embora esses sejam espaços de calma, são espaços criados e definidos a partir das relações de poder situadas no espaço escolar. O poder circula, funciona em rede, o que contribui para as diferentes formas de uso e apropriação dos espaços. As heterotopias podem ser vistas como a negação do instituído, pois são práticas de resistência que subvertem os sentidos e transformam as ações.

As heterotopias são lugares que se distinguem de todos os outros, lugares que se opõem aos outros, são de alguma maneira contraespaços. As crianças conhecem bem esses contraespaços, essas utopias localizadas que permitem o imaginário (FOUCAULT, 2013). Provavelmente, não há uma única cultura que não tenha constituído uma heterotopia (FOUCAULT, 2009a). Nesse sentido, a quadra de esportes, as áreas verdes e a biblioteca, quando utilizadas como refúgios, como espaço de 'fuga' do ambiente escolar, tornam-se heterotopias. Esses espaços estão conectados a todos os outros espaços, porém são definidos a partir de suas posições ou contra posições.

A quadra porque a gente no recreio joga bola, se divertia. (Guilherme, 39 anos, professor do Ensino Médio)

Ficava o dia inteiro na biblioteca, a biblioteca era o meu espaço. (Adriano, 44 anos, professor do Ensino Superior)

Eu sempre gostei muito da biblioteca, era o meu refúgio. (Sergio, 46 anos, professor do Ensino Superior). 
Plantando o jardim, plantando o pomar, plantando árvore com os alunos. A gente queria um ambiente humano, humanizado, gostoso, um lugar que realmente fosse aconchegante pra gente ficar. (Raquel, 48 anos, professora do Ensino Médio)

A área no entorno, no nosso caso era uma área muito grande com mata, com horta, com campo de futebol, então um lugar onde as crianças podiam correr e podiam ter seus momentos de solidão e de confissão. Onde eu tinha esses momentos. Eu acho isso muito importante. Na escola que eu dou aula hoje, eu caminho aqui no intervalo e eu vejo as crianças empilhadas, você não consegue nem ver onde tem um grupo brincando e o outro já pela sala de estudo... Eu acho que as crianças precisam de muito espaço e essa escola tinha. A outra tinha porque a gente corria em lugares proibidos [que eram os corredores]. (Eduardo, 50 anos, professor do Ensino Médio)

As falas acima trazem representações pontuais de espaços onde seus usuários mais se adaptavam: as áreas verdes, a quadra de esportes, a biblioteca e até mesmo os corredores do professor Eduardo que tinham 'sabor' de transgressão. Esses espaços demonstram uma visão particular das suas práticas cotidianas, das vivências e dos interesses. São as visões subjetivas de Eduardo, Raquel, Sergio, Adriano e Guilherme sobre o espaço escolar que estão representadas em suas memórias. Além disso, nessas falas, encontramos expressões que qualificam seus espaços de heterotopia: "se divertia”, "era o meu espaço", "era o meu refúgio”. Se as heterotopias são espaços que se opõem aos outros, são contraespaços, podemos fazer a relação e dizer que a escola rememorada por esses professores não era divertida e não possibilitava uma sensação de pertencimento.

Cada heterotopia tem um funcionamento preciso. O jardim/áreas verdes podem justapor em um só lugar vários espaços e significações: humanizador, calmante, estético. Além disso, podem possibilitar, ao mesmo tempo, usos e significações múltiplas. "As bibliotecas são heterotopias nas quais o tempo não cessa de se acumular e de se encarapitar no cume de si mesmo" (Foucault, 2009a, p.149). Já a quadra de esporte é uma heterotopia que tem na sua característica mais marcante o fato de parecer aberta, mas na realidade é excludente, pois só é habitada pelos que sabem praticar o esporte praticado na quadra.

Todo canto de uma casa, todo ângulo de um quarto, todo espaço reduzido onde gostamos de encolher-nos, recolher-nos em nós mesmos, é, para imaginação, uma solidão, ou seja, o germe de um quarto, o germe de uma casa, o germe de uma 
escola, que possui espaços de imobilidade, de refúgio e do imaginário. (BACHELARD, 2008, p.145)

Descrever as configurações das áreas verdes, da quadra de esportes e da biblioteca utilizando o conceito foucaultiano de heterotopia é perceber o espaço que habitamos por meio das relações de posicionamentos. Nesse sentido, esses espaços reais estão fora de todos os lugares comuns vividos em uma escola. Parecem ser lugares desencaixados do espaço escolar. São lugares que se opõem a todos os outros, são uma contestação aos espaços disciplinadores e normativos, portanto são contraespaços ou outros espaços reais, heterotopias que criam um espaço de ilusão (quadra de esportes), ou um espaço de compensação (áreas verdes e biblioteca).

A partir das heterotopias podemos perceber a escola como um lugar que permanece e diversifica-se por meio das relações de poder. Dessa forma, as relações de poder podem ser lidas tanto pelas práticas da gestão escolar, quanto pelas práticas cotidianas de reapropriação, ressignificação, definição e organização dos espaços.

\subsection{Espaço, Gênero e Diversidade Sexual}

A construção do gênero é social e cultural e o espaço por meio de suas características físicas, simbólicas e de relações influência na vivência e construção do gênero. Baseada na estrutura identitária binária menino-menina, a escola muitas vezes consolida e reafirma diferenças de valores entre o masculino e feminino que geram desigualdades. As formas de habitar o espaço e as relações implícitas a ele propiciam o acolhimento ou não das diferenças e podem possibilitar a naturalização do que é ser masculino e do que é ser feminino.

Ah, eu sempre gostei de quadra. Sempre gostei de espaço, de quadra de vôlei, eu joguei vôlei a vida inteira. Frequentava a quadra de esportes até depois das aulas, os meninos freqüentavam. (Adriano, 44 anos, professor de Ensino Superior)

Tinha fila de menina e fila de menino. (Raquel, 48 anos, professora de Ensino Médio) 
A gente achava aquilo horrível [ $\underline{\text { recreios de meninos e meninas }}$ separado] . A gente burlava, tinha uma parte por traz da escola $e$ os meninos passavam lá pro nosso pátio e aquelas brincadeiras de adolescente era tudo junto. (Renata, 39 anos, professora de Ensino Médio)

A partir das falas acima, percebemos como a distinção de gêneros influência na forma de habitar o espaço escolar: locais mais frequentados por meninos, filas separadas por gênero. Essas diferenciações espaciais por gênero, que segregam lugares para meninos e meninas na escola, perpetuam as fronteiras de gênero presentes na sociedade.

$\mathrm{Na}$ minha pesquisa de final de curso de pedagogia, que mencionei anteriormente no 'capítulo 1 - Construção do Objeto de pesquisa', percebi que durante o recreio a quadra de esportes era um território ${ }^{17}$ masculino. Esse dado se repetiu nessa pesquisa: sete professores dos onze entrevistados tinham alguma ligação com a quadra de esportes. Já todas as professoras entrevistadas, até a de Educação Física, não tiveram ligação nenhuma com a quadra de esportes quando alunas.

A primeira vista, pode parecer que essa dominância masculina da quadra de esportes seja reflexo de preferências naturais, aptidões distintas entre feminino e masculino. Mas os modos como meninos e meninas habitam a escola correspondem a um aprendizado cultural e social e por naturalização e padronização desses processos pela escola.

Reproduzo abaixo trecho da narrativa que ouvi do professor Adriano que mostra o processo de silenciamento da escola em relação à diversidade sexual:

Ah, eu não gostava do espaço do banheiro. Acho que por conta da minha sexualidade. E o espaço do banheiro sempre foi tenso por conta da homossexualidade e eu acho que um espaço tenso pra todos os meninos homossexuais. E eu lembro que eu criava, criei um mecanismo de ver que hora podia ir ao banheiro. Eu não ia ao banheiro quando tinha vontade, primeiro eu segurava o máximo que podia pra não ir ao banheiro, até quando não dava. A hora de ir ao banheiro era na metade das aulas, porque na minha cabeça, no início da aula e no final da aula os alunos pediam pra ir ao banheiro e o professor deixava ir ao banheiro. Então eu deixava pra ir ao meio da aula que a possibilidade de estar vazio era mais certa. O espaço do banheiro masculino ser extremamente aberto me incomodava muito. (Adriano, 44 anos, professor do Ensino Superior).

\footnotetext{
${ }^{17}$ Utilizo o termo território como um espaço/lugar com fronteiras fortes e demarcadas física e simbolicamente. Um lugar onde você precisa fazer parte de um grupo para freqüentar.
} 
O processo de ocultamento de determinados sujeitos pode ser flagrantemente ilustrado pelo silenciamento da escola em relação aos/às homossexuais. No entanto, a pretensa invisibilidade dos/as homossexuais no espaço institucional pode se constituir, contraditoriamente, numa das mais terríveis evidências da implicação da escola no processo de construção das diferenças. De certa forma, o silenciamento parece ter por fim "eliminar" esses sujeitos, ou, pelo menos, evitar que os alunos e as alunas "normais" os/as conheçam e possam desejá-los/as. A negação e a ausência aparecem, nesse caso, como uma espécie da garantia da "norma" (LOURO, 2001, p.89).

Como o espaço é construído para o que se pensa ser o 'aluno padrão' a questão da diversidade sexual nem sempre (ou nunca) é lembrada. Espaços são pensados, construídos de forma padronizada, dificultando o processo de habitar e pertencer dos 'alunos fora do padrão'. Dessa forma, mais do que simplesmente apresentar e construir um ambiente, o espaço constrói um discurso, um discurso ao mesmo tempo escandalosamente explícito, como naturalizado, um discurso que grita o que é normalidade, quem está ou não incluído na escola.

\subsection{Espaço e vigilância}

“A disciplina é, antes de tudo, a análise do espaço. É a individualização pelo espaço, a inserção dos corpos em um espaço individualizado, classificatório, combinatório" (FOUCAULT, 2008b, p.106).

A Escola possui dispositivos panópticos e disciplinadores: ponto dos professores e funcionários; diário de classe; a guarita; murais de aviso; visor nas portas das salas de aula; portas dos boxes dos banheiros; símbolos religiosos em salas de aula; capelas, símbolos e privilégios para os bons alunos são alguns desses dispositivos.

A disciplina é uma técnica de poder que implica uma vigilância perpétua e constante dos indivíduos. Não basta olhá-los às vezes ou ver se o que fizeram é conforme a regra. E preciso vigiá-los durante todo o tempo da atividade e submetêlos a uma perpétua pirâmide de olhares. (FOUCAULT, 2008b, p.106)

A guarita é um símbolo de segurança e ao mesmo tempo de controle; ninguém entra ou sai sem ser notado. $\mathrm{O}$ visor nas portas permite que vejam o que está acontecendo em sala de aula mesmo com a porta fechada. As portas dos boxes dos banheiros, que são elevadas e não tocam o chão, têm dupla função. A 
primeira é a de possibilitar melhor a limpeza, pois a vassoura ou rodo não esbarram nela. A segunda é permitir uma privacidade controlada: quem está dentro do boxe sabe que não está totalmente oculto, pois quem está fora pode controlar, mesmo que parcialmente, o que acontece nos boxes. O mural é um local onde são colocados avisos e cartazes selecionados pela escola.

O espaço arquitetônico continua a articular a ordem social [...] o ambiente moderno construído ainda mantém uma função educativa: seus sinais e cartazes informam e dissuadem. (TUAN, 1983, p.129)

Os símbolos e privilégios para os bons alunos são maneiras de vigiar sob uma perspectiva disciplinar e de reafirmar a conduta positiva e punir a conduta não desejada.

Tudo isso vem sendo feito em nome da nossa segurança individual, em nome do menor risco social, em nome da democratização e da cidadania, em nome do progresso e do nosso próprio conforto. Mas é preciso compreender que tudo isso funciona, também e principalmente, como novos dispositivos de subjetivação, como novas técnicas de controle, um controle baseado na visibilidade minuciosa total e permanente (VEIGA-NETO, 2003, p.118).

Aí tinha um lacinho com um alfinetinho e pregava na roupa da gente, verde e amarelo bem brasileiro, pra destacar que você era um aluno modelo, um aluno destaque. Eu usava aquilo e sentia mal-estar em relação aos meus colegas. [...]

Eu pelo menos sentia muito prazer naqueles espaços e como boa aluna, eu tinha livre acesso em quase todos os espaços, inclusive voltava pra escola pra quase assim... Fazer serviços voluntários... A pedido da diretora pra ajudar, organizar biblioteca essas coisas. (Renata, 39 anos, professora de Ensino Médio)

Inclusive, de áreas em que você não podia entrar dentro da escola. Tinha uma área que era exclusiva, nem só dos professores, mas das Irmãs mesmo, entendeu?Tinha uma área que as irmãs podiam ir, só elas; uma área que os professores podiam ir; uma área que os alunos podiam. Então, assim, era tudo muito bem dividido. [o corredor] Era um pouco aflitivo, você tava sempre, assim... Como era escuro, como se fosse isso aqui com a sala de aula, aqui e do outro lado. Ilumina, mas não ilumina. E assim, a impressão que você tinha era que se caísse ali, que se esbarrasse ali fazia um barulho estrondoso. Então, era o lugar perfeito pra ser vigiado. Você tinha que andar de meia alí, você não ia andar de meia, então você fazia barulho ao andar... Tava sempre... Tinha uma capela no final, com uma luz vermelha acesa, que era uma coisa bastante... Uma onipresença de vigilância [...] Tinha uma área que as irmãs podiam ir, só elas; uma área que os professores podiam ir; uma área que os alunos podiam. Então, assim, era tudo muito bem dividido. Aí, depois [...], eu fui pra outra escola, que era um 
espaço muito mais zoneado. (Gustavo, 40 anos, professor do Ensino Médio)

No $1^{o}$ colégio também tinha e esses corredores que a gente ia meio que na clandestinidade também a gente gostava. Aí também corria pelos corredores, o espaço de criança mesmo, mas sem os adultos saberem[...]. São pessoas do tamanho do meu pai e estavam sentadas em escola como eu... E em silêncio, não gostavam que a gente espiasse. E isso pra mim era uma coisa meio intrigante $[\ldots]^{18}$. As lembranças que eu tinha do colégio de padres eram assim, que também tinham professores leigos no colégio de padres... Os padres não davam aulas, eram professores muito tradicionais, muito exigentes... Eu comento com meus alunos até hoje, onde eu vi violência física, sabe? (Eduardo, 50 anos, professor do Ensino Médio).

As proibições de acesso a determinados espaços, sensação de vigilância permanente, violência física para manter a disciplina, sistemas de diferenciamento para os bons alunos, todas essas atitudes expostas nas falas acima são técnicas de poder que permitem esquadrinhar o espaço pelo uso da disciplina, marcar a hierarquia de poder e de controlar a forma de habitar o espaço escolar. "A disciplina é o conjunto de técnicas pelas quais os sistemas de poder vão ter por alvo e resultado os indivíduos em sua singularidade" (FOUCAULT, 2008b, p.107).

Os esses instrumentos descritos pelos entrevistados se tornaram formas eficazes de controle dos alunos, o que provoca uma relação de vigilância e punição entre os atores da educação. É nesse embate de forças internas da escola e dos alunos com a instituição escolar que podemos perceber o quanto o poder da disciplina regula o espaço escolar de forma difusa, múltipla e polivalente.

As duas últimas falas acima, além de exemplificarem as técnicas de poder que são utilizadas no espaço escolar demonstram percepções diferentes em relação a um espaço muito comum aos prédios escolares: o corredor ${ }^{19}$. Para Eduardo, o corredor é um espaço de transgressão, já para Gustavo, um espaço de vigilância. O corredor carrega diferentes significados, dependendo da forma como é percebido ou utilizado, depende da simbologia atribuída a ele. Essas diferentes

\footnotetext{
${ }^{18}$ No colégio onde Eduardo estudava, também funcionava uma faculdade. Ver adultos estudando causava estranheza.

${ }^{19} \mathrm{Na}$ minha dissertação de mestrado (Percepções e Vivências do Espaço na EJA: Em zigue-zague, chegar ao final do corredor' - 2010), os alunos atribuíam ao corredor um valor simbólico: de progressão nos estudos. Chegar ao final do corredor é alcançar uma grande realização para os alunos do curso de EJA da escola estudada, significa a tão esperada conclusão dos estudos.
} 
formas de percepção podem ser atribuídas ao caráter relacional do espaço e, também, porque o espaço está sempre em construção por seus usuários, por ser um constructo social e cultural. 


\title{
4. Espaços e tempos de professor: construções e representações espaciais
}

\begin{abstract}
A nuança não é uma coloração superficial suplementar. Portanto, é preciso dizer como habitamos o nosso espaço vital de acordo com todas as dialéticas da vida, como nos enraizamos, dia a dia, num 'canto do mundo (BACHELARD, 2008, 24).
\end{abstract}

Este capítulo procura perceber e compreender as construções e representações espaciais dos professores entrevistados construídas pelas vivências do espaço escolar. O capítulo está dividido em subitens, mas as discussões se entrelaçam, pois as questões aqui apresentadas perpassam pela prática docente desses professores.

A relação entre o ser humano e o espaço que habita comporta diversas dimensões: físicas, econômicas, políticas, sociais, religiosas e simbólicas. Todas essas dimensões estão em permanente interação durante o processo de habitar e pertencer ao espaço. Nesse sentido, o espaço escolar comporta significados produzidos coletivamente que garantem certas práticas espaciais e certa simbologia de como utilizar esse espaço, caracterizando uma dimensão simbólica.

Manifestações espaciais da cultura, os lugares simbólicos estão impregnados de significados políticos, religiosos, étnicos ou associados ao passado, o que os torna dotados de uma singularidade simbólica, distintos qualitativamente dos demais lugares caracterizados por uma diferenciação quantitativa. (CORRÊA, 2012, p.138139).

Ainda de acordo com Corrêa (2012), as práticas simbólicas espaciais podem se realizar em fluxos ou em fixos ${ }^{20}$, isto é, em localizações ou em itinerários. Palácios, templos, shoppings e igrejas podem ser exemplos de fixos espaciais. Já procissões, paradas e desfiles são fluxos espaciais. Levando em conta esse

\footnotetext{
${ }^{20}$ Fixos e fluxos são um conceito criado por Milton Santos em 1978 e retomado e revisto no livro 'A Natureza do Espaço' (2008) que considera o espaço como um conjunto de fixos e fluxos. Muito resumidamente, para o autor, fixos são elementos "fixados em cada lugar, permitem ações que modificam o próprio lugar, fluxos novos ou renovados que recriam as condições ambientais e as condições sociais, e redefinem cada lugar. Os fluxos são um resultado direto ou indireto das ações e atravessam ou se instalam nos fixos, modificando a sua significação e o seu valor, ao mesmo tempo em que, também, se modificam. Fixos e fluxos juntos, interagindo, expressam a realidade geográfica e é desse modo que conjuntamente aparecem como um objeto possível para a geografia. Foi assim em todos os tempos, só que hoje os fixos são cada vez mais artificiais e mais fixados ao solo; os fluxos são cada vez mais diversos, mais amplos, mais numerosos, mais rápidos" (SANTOS, 2008, p. 61-2).
} 
conceito de fluxos e fixos para a realização de espaços simbólicos, penso que o espaço escolar é o resultado constante das interações entre fixos (infraestrutura) e fluxos (contatos humanos, trocas de conhecimento e informação), materialidade e imaterialidade, razão e emoção que constroem o simbolismo da escola e influenciam no seu habitar.

Os significados simbólicos que estão impregnados nos espaços permitem que este se diferencie dos demais, tornando um espaço singular, único. Essa diferenciação, essa singularidade permite a percepção de diferenças de um estabelecimento de ensino para outro. Corrêa (2012) afirma que o sentido simbólico que é dado a um determinado espaço é proveniente tanto de seus habitantes, quanto por pessoas externas como a comunidade ao redor, Estado e grupos empresariais.

Além disso, o espaço é entendido como posicionamento. "O lugar que cada corpo ocupa no espaço faz sentido não por si mesmo, mas em função das suas relações com os lugares vizinhos" (VEIGA-NETO, 2007, p. 256). Essa característica de posicionalidade do espaço nasce de seu caráter relacional, o que constrói a possibilidade da articulação da representação da memória com o espaço físico com o espaço vivido e percebido. Nessa perspectiva, a posição ocupada em uma escola é por si mesma uma variável decisiva do que é, e como é percebido e representado.

Nessa perspectiva, pelas falas dos professores podemos perceber que as mudanças no espaço físico são menores que as mudanças no espaço simbólico.

Não, o formato era a mesma coisa. Continuava o quadro, aí já tinha com alguma coisa em quadro branco, na Federal já tinha alguma ou outra sala em quadro branco, que era uma novidade pra mim e tal. A sala continuava com o mesmo padrão que tem até hoje, professor na frente, quadro nas costas dele $e$ disposição em colunas de carteira, mas mesmos as salas sendo parecidas, tinha diferença entre as aulas no Ensino Médio e da faculdade. Eu me vejo diferente ministrando aulas para o curso técnico e para o curso superior. (Tadeu, 51 anos, professor do Ensino Superior)

A experiência que eu tive na escola da prefeitura é uma coisa curiosa porque inicialmente a situação lá era muito precária, aí mudou pra um prédio novo, mas os alunos, por incrível que pareça, ainda preferiam o prédio antigo que era mais precário. O prédio antigo, era uma casa, eles falavam que era uma casa mal assombrada, tinha a moça do vestido branco que aparecia 
a noite. Eles gostavam mais de lá do que o prédio novo. (Leonardo, 41 anos, professor do Ensino Médio)

Tadeu e Leonardo conseguem expressar o lado simbólico, relacional e o valor afetivo do espaço. Tadeu percebe diferenças entre as aulas do Ensino Médio e da faculdade, apesar dos espaços físicos serem muito semelhantes um ao outro. Nesse sentido, Tadeu relata os valores simbólico e relacional do espaço da sala de aula o que influencia em sua prática docente. Já Leonardo aponta a preferência de seus alunos por um prédio precário, mas repleto de simbolismos e afetividade, explicitando assim, que o espaço possui valores que vão além dos funcionais.

As disposições temporais e espaciais regulam a conformação acadêmica e pautam coordenadas básicas de aprendizagem como pontualidade, organização, valores morais e culturais.

Como o espaço escolar é um devir e sua percepção e construção depende das experiências passadas, dos valores e conceitos internos, o ambiente da escola se modifica a partir das memórias, crenças de seus atores e a partir da circulação das imagens e, em última análise, das representações.

Olha, tinha sala de aula padrão como tem hoje, quadro, carteirinhas enfileiradas, tinha salas de aula como um anfiteatro e que não tinham carteiras, eram mesas, era um palco grande e a gente se sentava como em uma arquibancada. $O$ professor lá na frente, em baixo, não era o professor no alto, o professor ficava embaixo. Quadros gigantescos tomavam conta da parede inteira [...]. Eu me sentia mais confortável nessa sala anfiteatro, do que sentar enfileirado um atrás do outro; era mais confortável, era mais agradável. Não no sentido de ser superior, àquelas questões que a gente conheceprofessorem cima, alunos em baixo -, mas em termos de você estar vendo o professor sempre. Essa é uma questão. A gente enfileirado não vê o professor sempre [...]. Pra você ver, o professor de fisica que era o carrasco, ele dava aula nesse anfiteatro que a gente ficava em cima. Já o professor de francês, dava aulas na sala de carteira uma atrás da outra, mas esse professor ele andava dentro de sala de aula, ele brincava, ele botava a mão nos alunos. Tudo ele representava, quando cantava música em francês ele dançava, ele cantava. Então, olha só, numa sala de aula que a gente se sentia mais agradável tinha uma aula que era terrivel, na outra que era mais desconfortável a aula era boa [...] Tento deixar meus alunos confortáveis em qualquer sala de aula. (Tiago, 52 anos, professor do Ensino Superior).

Tiago relata novamente o caráter simbólico, relacional, mas traz mais uma característica da espacialidade: sua constante transformação. Um espaço se 
transforma a partir de seus habitantes, podendo se tornar mais adequado, mais prazeroso ou não, se tornar um lugar de desconforto. Tudo depende da forma como as relações acontecem e qual valor é atribuído a esse lugar.

O espaço é produto de interrelações, o que permite a possibilidade da existência da multiplicidade e, portanto, ter a característica de estar sempre em construção, nunca está terminado, estar em permanente mudança. Dessa forma, espaços agradáveis podem se tornar incômodos e vice-versa, dependendo de como é habitado, dependendo de como as relações acontecem.

Como um espaço ganha ou perde significados, sentidos e significações? Como muda seu conteúdo? Há espaços não-significantes?

Em princípio é possível encarar a questão da semantização/dessemantização do espaço sob dois ângulos distintos: o discurso sobre o espaço e a prática do espaço. (COELHO NETTO, 2009, p. 117-8)

O espaço ganha sentido (é semantizado) a partir da prática física, imaginária/simbólica e relacional do mesmo. Essas práticas se interagem, estão ligadas e concretizam o habitar do espaço. Bachelard (2008) exemplifica a interação dessas práticas quando fala do porão. Inicialmente, o espaço do porão se relacionará com o corpo de quem o visita (sensações térmicas e de luminosidade, isto é, percepções físicas). Ao mesmo tempo essas percepções trarão cargas afetivas "inerentes a toda convivência com um espaço" (COELHO NETTO, 2009, p.119) e começará acontecer ligações dessas percepções com o imaginário e com o simbólico (segurança, insegurança, fantasias). Esse imaginário/simbólico acontecerá de acordo com as relações sociais e discursos sobre o espaço nele contido. Em contra partida, um espaço pode passar por um processo de perda de sentido (ser dessemantizado) quando ele não pode ser vivenciado ou quando existe um discurso que desvalorize esse espaço ou um discurso que suprassemantize outro espaço (COELHO NETTO, 2009).

\subsection{Espaço e Poder}

Neste item farei uma discussão sobre o espaço e as relações de poder. Como a questão do poder perpassa todo o espaço escolar, esse tema já apareceu em itens 
anteriores dessa tese e continuará a aparecer em outros ${ }^{21}$, mas resolvemos explicitar essa discussão, pois alguns professores relataram perda do poder para agentes externos à escola: a publicidade e as avaliações externas e a agentes internos: os celulares trazidos pelos alunos e a hierarquia entre as disciplinas, isto é, diferença de prestígio entre as disciplinas escolares.

O poder é um feixe de relações mais ou menos organizado, mais ou menos piramidizado, mais ou menos coordenado [...]. Mas se o poder na realidade é um feixe aberto, mais ou menos coordenado (e sem dúvida mal coordenado) de relações, então o único problema é munir-se de princípios de análise que permitam uma analítica das relações do poder. (FOUCAULT, 2008b, p.248)

Nesse sentido, o poder pode ser compreendido como um conjunto de relações, uma matriz de forças que, em determinado contexto histórico, produz assimetrias e pode ser percebido de acordo com seu funcionamento material que investe suas ações nos indivíduos - corpo, comportamento, hábitos, discursos e saberes.

Hoje, nós somos impotentes pra impedir o aluno de trazer espelho pra sala de aula, que é o celular, é muito pior do que uma televisão, muito mais! Tem um poder muito maior do que uma televisão. Então hoje eu dou aula pra alunos que estão em frente ao espelho, eu sou um som na casa, eu sou um som de rádio na casa enquanto eles se olham no espelho. Eles se olham profundamente no espelho, uma casa de espelhos, né, o celular. (Eduardo, 50 anos, professor do Ensino Médio).

É uma idade mais difícil ${ }^{22}$,é uma era mais difícil, essa era do celular, é era da internet no celular, é a era de uma série de atrativos maiores do que o que você tá lidando ali na sala. (Eliana, 38 anos, professora do Ensino Superior).

O celular é um agente de dispersão em sala de aula, uma vez que é mais atrativo do que está sendo apresentado pelo professor. Facilita a comunicação, por meio de apps ${ }^{23}$, com o colega ao lado, de outra classe ou outra escola. Nessa perspectiva, a complexidade do trabalho docente aumenta, pois

as novas culturas juvenis exigem do professor uma implicação pessoal e moral importante, um sentido de responsabilidade grande, pois muitas e contraditórias são as competências exigidas. (LELIS, 2012, p.160)

\footnotetext{
21 A Discussão 'poder e espaço' apareceu mais explicitamente no item 4.5 e aparecerá nos itens 5.3 e 5.4. Mas essa discussão transcorre por toda tese.

${ }^{22}$ Entre 18 e 20 anos. Idades das pessoas que iniciam curso superior na instituição educacional em que a professora entrevistada leciona.

${ }^{23}$ Whatsapp, Facebook, Instagram, Viber, Mensseger, etc.
} 
Além do telefone celular, a variação de prestígio entre as disciplinas escolares, que cria uma hierarquia entre as disciplinas, é apontada pelos professores como uma forma de perda de poder, como podemos perceber nas falas de Mariana e Sonia.

Educação física, de artes, todas essas disciplinas, eu não sei por que, mas essas disciplinas não eram valorizadas no curso técnico. (Mariana, 37 anos, professora do Ensino Médio)

Algumas disciplinas são consideradas mais importantes que outra. Nunca tive esse problema, mas já vi colegas de Filosofia, Sociologia, penando por ter sempre a última aula... (Sonia, 26 anos, professora do Ensino Médio)

A diferença de prestígio entre as disciplinas escolares influencia na utilização do espaço e na percepção do professor sobre as possibilidades de mudança. O prestígio das disciplinas é produzido no interior da escola, nas relações de poder e na interação com a cultura escolar. A disputa pelo prestígio e poder está exibida na grade curricular: presença de uma disciplina e ausência de outra, carga horária maior ou menor, disciplinas obrigatórias e disciplinas eletivas, melhor dia e horário para algumas disciplinas. Além disso, em alguns casos, disciplinas de prestígio dispõem de espaços físicos e infraestruturas melhores ou mais adequadas.

Eduardo aponta outro mecanismo de perda de poder do docente: a publicidade. Para ele, a publicidade incentiva um desejo consumista nos alunos que os fazem querer aprender somente o que no futuro poderá gerar dinheiro.

[a publicidade] Ela é muito mais poderosa. Eu acho que o desafio dos países hoje é o seguinte: como sendo a publicidade um elemento fundamental do capitalismo, pra estimular a sociedade do consumo, como você consegue educar uma mão de obra qualificada numa situação dessas. Como se não precisasse. Sabe qual é a resposta que países centrais dão a isso... Os Estados Unidos, por exemplo, eles não conseguem mais fazer com que os jovens fundamentais estudem física, química, as matérias que é preciso ter uma autoridade muito grande, precisa ter uma humildade muito grande. Pra que isso serve? Não serve pra mim [falam os alunos]. [para os alunos] eu sou apenas um instrumento pra transferir esse conhecimento [...]. Eles, os EUA vão buscar na Índia, na Colômbia, onde as sociedades não são tão consumistas e onde os jovens ainda constroem uma personalidade em cima dessa alteridade de aprender ciências. (Eduardo, 50 anos, professor do Ensino Médio) 
Nessa perspectiva, para o aluno extremamente influenciado pela propaganda e o consumismo, o professor torna-se um instrumento para passar conhecimentos.

Ou seja, a mudança do trabalho do professor provocada pelo papel crescente dos meios de comunicação de massa, das tecnologias da comunicação, mas também pela crise dos modelos de autoridade, passou a requerer dos docentes habilidades não regulamentadas pelas burocracias, mas valorizadas social e institucionalmente e que incluem componentes éticos, afetivos e emocionais (LELIS, 2012, p. 160).

Outra forma de perda de poder apontada pelos professores, principalmente pelos que lecionam no Ensino médio, são as avaliações externas de acesso à universidade.

O ensino médio, ele é todo voltado pro vestibular. Então a gente tem todo o enfoque em Pism, Enem, em provas de vestibular. É um estudo ainda mais maçante, poucas apresentações de trabalho, sempre avaliando pra prova, pensando no vestibular. Também o meu ensino médio foi todo voltado pra isso. (Sônia, 26 anos, professora do Ensino Médio)

Como eu sempre atuei mais no ensino médio, quando eu entrei na sala de aula já existia o Pism ${ }^{24}$, então sempre estive preocupado com esse programa do Pism. Então acaba que são aulas muito expositivas. Porém a maneira como eu exponho isso tem algumas coisas que eu acho que são bacanas, por exemplo, trabalhar em uma escola particular de elite sempre me proporcionou ter muito material a disposição, então Datashow, computador, sala de vídeo... Muitos materiais... Então eu sempre usei muitos recursos audiovisuais. (Leonardo, 41 anos, professor do Ensino Médio)

Os exames externos de acesso à universidade são outro desafio para os professores que, guiados por uma política de resultados, perdem autonomia e podem se transformar em meros preparadores para avaliação.

Além da hierarquia administrativa e pedagógica que controlam o professor e a submissão às decisões do Estado, o docente está sujeito a novas formas de exercício do poder seja interna ou externamente ao espaço da sala de aula.

O poder só existe na ação, no ato. Seus modos de aplicação cruzam práticas, saberes e instituições. O uso do celular pelos alunos demonstra a diferenciação de papeis e uso do espaço no modelo escolar: a maior parte do tempo em sala de aula o aluno assume uma postura passiva, não participativa: sentado em fileira, escutando, anotando. Esse ‘ócio' físico possibilita o uso do aparelho e de estar ao

\footnotetext{
${ }^{24}$ O Programa de Ingresso Seletivo Misto (PISM) é um processo de avaliação seriada, em que os candidatos às vagas oferecidas pela UFJF (Universidade Federal de Juiz de Fora) participam de três módulos de avaliação, um ao final de cada série do Ensino Médio.
} 
mesmo tempo dentro e fora da sala de aula. Já os exames de acesso à universidade (Pism e Enem) são instrumentos formas de institucionalizar o poder sobre a autonomia do professor, direcionando-o a ministrar conteúdos padronizados e considerados mais importantes pelo Estado e/ou pela universidade. A influência da publicidade sobre os alunos, como dispositivo de subjetivação e sua interferência em sala de aula demonstra que as relações de poder existentes no espaço escolar são semelhantes às relações de poder que ocorrem na sociedade onde a escola está inserida.

Essas novas formas de poder ainda não provocaram uma mudança concreta na materialidade do espaço escolar, mas já trazem mudanças no espaço simbólico e das relações. "O espaço vive, repira-se - e isso quer dizer que exige mudança (o homem as exige para ele e através dele)!" (COELHO NETTO, 2009, p.70).

O discurso da racionalidade, a separação entre o científico e não científico geram um discurso que a partir da articulação poder e saber faz nascerem efeitos de verdades. Esses jogos de verdade fazem de uma prática ou um discurso um lugar de poder. Isso é percebido no interior da escola nas disputas de prestígio entre as disciplina escolares.

Onde há poder, ele se exerce. Ninguém é, propriamente falando, seu titular; e, no entanto, ele sempre se exerce em determinada direção, com uns de um lado e outros do outro; não se sabe ao certo quem o detém; mas se sabe quem não o possui (FOUCAULT, 2008b).

As relações entre os sujeitos que habitam o espaço escolar reproduzem a circulação e rede de poder que existe na sociedade. Essa circulação de poder produz saberes.

O sujeito que conhece, os objetos a conhecer e as modalidades de conhecimento são outros tantos efeitos dessas implicações fundamentais do poder-saber e de suas transformações históricas. Resumindo, não é a atividade do sujeito de conhecimento que produziria um saber, útil ou arredio ao poder, mas o podersaber, os processos e as lutas que atravessam e que o constituem, que determinam as formas e os campos possíveis de conhecimento (FOUCAULT, 2009b, p.30).

O espaço escolar é um saber construído nas e pelas relações de poder. Nessa perspectiva, o espaço escolar é ideológico, uma vez que reafirma valores de quem o constrói cotidianamente. É disciplinador, pois estabelece limites e possibilidades de sua utilização, é representativo na medida em que provoca identificação nos 
seus frequentadores e é cultural, pois se modifica de acordo com as mudanças ocorridas em seus habitantes.

\subsection{Práticas e ideias pedagógicas}

As ideias pedagógicas decorrem da análise do fenômeno educativo, na busca de explicá-lo, ou derivam de certa concepção de ser humano, de mundo ou de sociedade sob a qual é interpretado o fenômeno educativo. Embora as ideias e práticas pedagógicas sejam ligadas ao contexto político, social e tecnológico, esse último é o mais percebido. $\mathrm{O}$ uso de meios tecnológicos é visto como algo essencial para conseguir a atenção dos alunos.

Eu derrubo as paredes de sala de aula utilizando a tecnologia, trago o mundo para sala de aula. (Tadeu, 51 anos, professor do Ensino Superior)

Eu tenho Datashow (projetor) para as aulas de desenho e pras aulas de informática. Uso o Datashow ligado no Ipad; aí a aula fica mais interessante porque eu posso mostrar vídeo, a forma de mostrar o conteúdo fica mais interativa, fica mais interessante. (Raul, 40 anos, professor do Ensino Superior)

Internet, recursos audiovisuais em geral fazem muita diferença, então na EJA, por exemplo, eu trabalhei a noite e tinha pouquíssimos recursos, era assim, se eu não passasse no quadro, tinha que fazer Xerox pra eles, lá tira cópia de Xerox, isso era um fator limitador. Então assim, a escola quando tem uma mecanografia, uma Xerox pra escola onde te disponibiliza preparar materiais isso é um salto porque dinamiza as aulas. Quando você fica restrito a passar matéria no quadro que eles não têm nem livro, nem Xerox, eu acho que se perde muito tempo, dificulta a prática. Eu acho que a tecnologia ajuda, eu acho que torna a aula mais... Menos monótona, digamos assim. Eu nunca fiz o uso exaustivo pra que aquilo não ficasse...Comum, mas é um uso bastante regular, digamos assim. (Leonardo, 41 anos, professor do Ensino Médio).

Com o uso da tecnologia o professor passa a ser mediador e não o detentor único do conhecimento. Dessa forma, o professor adquiri a tarefa de filtrar informações a partir de seus saberes. Além disso, a tecnologia passa a ser algo que aproxima professor e aluno, torna o abstrato visível e causa uma revolução na forma de aprendizagem que implica em uma mudança no trabalho docente. 
Ainda que sejam separadas didaticamente na historiografia da educação, as ideias pedagógicas e as ideias do que é ser professor são percebidas de forma entrelaçada pelos professores, sem muita distinção entre elas, pois são representadas pela relação professor-aluno. Pelas falas dos professores, percebemos que eles querem melhorar como docentes, lutar por infraestrutura pelos alunos, para conseguir uma boa relação com os discentes. A diferenciação entre uma prática pedagógica e outra é baseada na interação com o aluno, como o professor se relaciona com os estudantes e a classe.

Então, pra começar, e aí eu vejo tanto na minha formação quanto atualmente, eu não sei se há um... Descaso é uma palavra forte, mas há um certo cansaço na evolução da educação básica, parece que a aula é mais elaborada no $1^{\circ}, 2^{\circ}$, $3^{o}, 4^{o}, 5^{\circ}$ ano depois vai perdendo um pouco o gás, quando chega no ensino médio parece que se usam poucos espaços, se faz poucas dinâmicas, fica pouco atrativo, o menino já não quer ir aí fica mantando aula [...] enfim, se constrói isso. Aí quando você percebe que tem alunos, que aí eu fico me espelhando neles, que querem fazer educação física, eles vão, aí eles voltam a ter um estímulo e tal e aí ei percebo que pelo menos aqui, no meu trabalho, não tem muita diferenciação [da graduação]. A nossa aula de ginástica artística, de trampolime tal, é do mesmo, ou melhor, nivel do que na graduação. Não tem o espaço físico gigantesco como se tem lá na graduação, mas a gente tem os aparelhos que monta, desmonta, monta na quadra, entendeu? A gente tem como fazer ter a estrutura, digamos assim. E eu não tive isso, [...] eu não tinha espaço nenhum no fundamental, no ensino médio [...], no início da minha graduação era precário, não se tinha estrutura, mas aí depois melhorou bastante. Tem que se espelhar no aluno, tem que fazer a infraestrutura aparecer. (Mariana, 37 anos, professora do Ensino Médio)

Ter uma boa prática pedagógica, eu acho que principalmente ter atenção com o aluno. Você percebe que tem professor que não prepara a aula direito e que ele não presta atenção no aluno. Ele não presta atenção no aluno então ele não dá um retorno para o aluno, tanto faz se você foi bem, se você foi mal. (Renata, 50 anos, professora do Ensino Médio)

Acho que o professor tem que ser próximo do aluno, que dê uma liberdade para que o aluno possa chegar perto do professor e te dar aquele feedback, se a aula está sendo legal ou não. Então eu acho que o professor tem que estar com essa cabeça aberta porque cada turma é uma turma então você não pode usar um padrão pra todos, então você ter essa percepção de como está sendo o retorno da turma, se está sendo positivo ou se não está. E a questão da auto avaliação, é você ter uma liberdade, dar uma liberdade para o aluno, lógico que dentro 
de um limite, mas que você possa estar perceptivo a essas questões. (Erica, 37 anos, professora do Ensino Superior)

Para as professoras Mariana, Renata e Erica o principal para uma boa prática pedagógica é a atenção com o aluno e a importância de perceber as necessidades do mesmo. Já para os professores Sérgio e Tiago, o mais importante é a proximidade física com o aluno: trazer a turma para perto do quadro, de onde está o professor, de circular pela sala.

Dá diferença, com certeza, dá muita diferença. Igual nesse exemplo que eu tenho de tirar o aluno do fundo da sala $e$ colocar eles em semicírculo próximo de mim [os alunos perguntam] 'Ah, professor. Tem que ir praí?' Eu falo: 'Tem. Hoje eu estou carente. Vem pra perto do professor.' Aí eles conseguem prestar muito mais atenção porque eu mesmo manipulo o foco deles pra mim, então isso faz toda diferença. (Sergio, 46 anos, professor do Ensino Superior)

Minha aula é o famoso cuspe e giz porque, minha aula é muito dialogada, muito conversada, eu tenho uma apostila que eu faço e eu venho atualizando sempre que é o carro chefe, é o esquema pros alunos acompanharem[...]. Não modifico [o espaço da sala de aula] não, mas eu ando pra caramba. Ando, brinco, estou dando aula e de repente eu falo um outro assunto completamente louco, fora do contexto, eu sou assim... Pra dar uma quebrada às vezes... Se a gente continua falando uma coisa só o tempo de 50 minutos, o aluno dorme, desanima. Tem que ter uma boa relação professor-aluno. (Tiago, 52 anos, professor do Ensino Superior)

Existem algumas diferenças entre o que os professores consideram boa relação professor-aluno, como pode ser visto nas falas a seguir. Enquanto o professor Julio prefere uma relação de respeito, mas sem amizade ou intimidade, o professor Leonardo já acredita em uma relação de amizade com os alunos.

Me baseio, eu sempre procuro estabelecer relação de respeito com o aluno, mas nunca de amizade, de intimidade, porque eu vejo que há uma tentativa de aproximação pelo fato de eu ser relativamente jovem, acaba que acontece essa aproximação. Então eu sempre procuro estabelecer essa relação de respeito, de poder ajudar, de me mostrar sempre aberto, no entanto não há relação de intimidade aluno-professor. (Julio, 34 anos, professor de Ensino Superior)

Eu sempre conseguia me aproximar muito dos alunos porque eu lembro que na escola particular eu era chamado [pelo apelido], então a minha relação com eles era muito boa. Tanto que eu sempre jogava vôlei com eles nas olimpíadas, era escolhido como professor padrinho da turma da olimpíada. 
Então minha relação sempre foi muito próxima. (Leonardo, 41 anos, professor do Ensino Médio)

Outra ideia de prática pedagógica escolhida por alguns professores é a oratória.

Fiz curso de oratória então eu entendo a importância de você organizar o espaço físico para o aprendizado do aluno ou pelo menos para ele prestar atenção então eu mexo muito no espaço físico. Às vezes eu chego em sala de aula, uma turma pequena, tem aluno que vai lá pro fundo da sala, então eu faço semicírculo [...]. Eu já tive uma turma que era horrível, eram 8 pessoas e eles sentavam todos no final da sala e ficavam conversando entre si e nem prestavam atenção em mim, então eu mudo eu faço dinâmica de grupo, eu passo vídeo, eu mudo o espaço físico sempre que eu posso. E acho que só não faço mais por causa dessa carga horária se não cada aula eu queria que fosse um espetáculo. (Sergio, 46 anos, professor do Ensino Superior)

Eu tento buscar os truques que os bons oradores utilizam em suas palestras, gosto muito de ver palestras. Hoje é muito fácil a gente olha no youtube, busca palestra. Gosto das técnicas dos palestrantes e tento buscar alguma coisa da tecnologia do que eles utilizam e utilizo também muito às vezes os canais religiosos, alguns bons oradores religiosos, que tem técnica de fala, de trazer a turma, de buscar picos de, digamos, de êxtase. Então eu tento passar pra sala de aula com variações de vozes muito acentuadas e tem funcionado muito bem. (Tadeu, 51 anos, professor do Ensino Superior)

Muitos dos entrevistados buscam inspiração em cursos de oratória para aprimorar sua prática pedagógica e melhorar a relação professor-aluno. Tentam aprender como segurar uma plateia, o que demonstra que esses professores percebem, mesmo que intuitivamente a mudança no alunado e que as ideias e práticas pedagógicas são fluidas e estão em constante modificação.

"O trabalho modifica a identidade do trabalhador, pois trabalhar não é somente fazer alguma coisa, mas é fazer alguma coisa de si mesmo, consigo mesmo" (TARDIFF; RAYMOND, 2000, p.209-10). Nessa perspectiva, a busca por cursos de oratória e outros tipos de aperfeiçoamento nasce da prática cotidiana e dos saberes que dela se originam.

A aprendizagem do trabalho do professor passa por uma escolarização, que muitas vezes é complementada com uma formação prática, pois

os saberes que servem de base para o ensino, tais como são vistos pelos professores, não se limitam a conteúdos bem circunscritos que dependeriam de um conhecimento especializado.Eles abrangem uma grande diversidade de objetos, de 
questões, de problemas que estão todos relacionados com seu trabalho (TARDIFF; RAYMOND, 2000, p.213).

O professor tem que se adequar, se adaptar, construir sua legitimidade, motivar o aluno, caminhar com a tecnologia, estar sempre atualizado, lidar com a diversidade e multiplicidade de classes, pois a vontade de estudar dos discentes não está garantida. Dessa forma, o papel do professor é fundamental, pois é ele quem dá os fundamentos e articula o espaço de sala de aula.

\subsection{Espaço e conteúdo da disciplina}

A escola tem sido e é um lugar de produção da cultura e essa cultura é objetivada nas práticas em que são operacionalizadas nos processos formativos. As ações se materializam nos espaços, objetos, ícones e os textos que fazem parte do patrimônio histórico-educacional. ${ }^{25}$ (ESCOLANO BENITO, 2012, p. 12)

Para os professores, os conteúdos das disciplinas impõem uma forma de lidar com o espaço escolar. Os professores se sentem limitados pelo conteúdo. Isso dificulta modificar a relação professor-aluno, arranjo do espaço físico e propor novas metodologias de aula. Para eles existem disciplinas que impõem o quinteto quadro - giz - carteiras enfileiradas - professor falando - alunos escutando e copiando.

O layout da sala acho complicado na disciplina matemática, haver alguma mudança pelo menos nos próximos anos. (Guilherme, 39 anos, professor do Ensino Médio)

A gente precisa de uma disciplina [matéria, conteúdo] que você possa ficar mudando o layout de sala pra poder passar o conteúdo, pois muitas vezes, na verdade o aluno tem que olhar para o quadro. (Raul, 40 anos, professor do Ensino Superior)

Pra minha disciplina eu não vejo necessidade [de modificar o layout da sala de aula], mas acontece em algumas disciplinas [a necessidade de mudar o espaço de espaço]. Eu ministro disciplinas que são muito dinâmicas, então eu tenho que sair de sala de aula. Eu dou aulas práticas, pra produção e iluminação de eventos muitas vezes, dou prova aula como uma pessoa

\footnotetext{
${ }^{25}$ Transcrevo aqui o texto original em espanhol: La escuela ha sido y es un lugar de producción de cultura y esta cultura se objetiva en las práticas en que se operativizan los procesos formativos. Las acciones se materializan em los espacios, objetos, iconos y textos que forman parte del patrimonio histórico-educativo.
} 
atuando, então fora de sala de aula é muito legal. (Julio, 34 anos, professor do Ensino Superior)

No relato dos professores acima, percebemos que eles se sentem aprisionados pelos conteúdos da disciplina, pois o conteúdo impõe uma forma de organizar o espaço escolar. Isso demonstra uma visão focada somente na característica física/material do espaço escolar.

Como vimos no capítulo dois, o espaço escolar é um devir e sua percepção e construção depende das experiências passadas, dos valores e conceitos internos. Nessa perspectiva, o ambiente da escola se modifica de acordo com as percepções, memórias e representações de como os professores pensam ser mais adequado para apresentar os conteúdos de uma disciplina.

Parece haver uma relação particular, não somente entre o espaço e nosso pensamento (ele mesmo preso a nossa ação), mas entre o espaço e a realidade exterior ou ainda entre o espaço e a matéria. (WORMS, 2010, p. 100)

Essas representações inconscientes ou não de como deve ser o espaço da sala de aula para determinada disciplina escolar podem levar a uma cristalização de uma mesma representação de que existem disciplinas que não necessitam de uma mudança espacial. "O espaço, como toda representação, é proveniente da vida, e deve essencialmente - até em sua estrutura mais íntima! - ter uma função prática." (WORMS, 2010, p. 100)

Esse pensamento de que a disciplina impõe um determinado espaço escolar, demonstra que o conceito de espaço que os professores entrevistados possuem é do espaço físico e que não vivem conscientemente ou não percebem (ou não lembram) o lado simbólico e relacional do espaço escolar. Isso também pode ser reflexo da memória de suas experiências enquanto aluno.

A memória, tal como exercida pelos diversos atores sociais, intervém, efetivamente, retendo certos elementos do passado e recompondo-os em representações julgadas pertinentes. Correlativamente, o esquecimento, voluntário ou não, está indissociavelmente a ele ligado. É o uso seletivo da memória que redefine o que é patrimônio dentro do que o passado deixou como testemunha de outros tempos (BERDOULAY, 2012, p.122-3).

A memória, real ou construída pela circulação do discurso, de ter estudado em contexto tradicional de educação pode influenciar nessa paralisação em relação à mudança do espaço da sala de aula e na imposição de que determinados conteúdos só podem ser ensinados se os alunos estiverem em sala de aula, 
sentados em fileira e o professor falando e escrevendo no quadro negro. Além disso, a ideia da classe como um espaço - tempo gerido por um professor, a distribuição e os usos dos espaços - são construções que constituem a cultura escolar.

\section{4. Espaço e controle: imposições}

O trabalho docente, quando considerado em sua totalidade, não se reduz à soma de seus elementos, mas sim nas suas relações essenciais, em suas características, saberes, identidades, especificidades que se articulam e que são responsáveis por sua produção e seu desenvolvimento.

"Os discursos e as expectativas recaem sobre o professor como se este fosse o salvador da pátria, mas, na prática, não são dadas a esse 'profissional' as condições necessárias de responder adequadamente ao que se espera dele" (LÜDK; BOING, 2004, p. 1175). O professor se sente e está subordinado ao limite do espaço físico, infraestrutura, decisões superiores da direção escolar, supervisão, políticas, troca de mobiliário.

Sempre gostei muito de movimentar carteiras porque eu trabalho em grupo, trabalho de debates a gente faz círculo, então tem todo esse processo. [...] E agora eu estou aborrecida porque eu tinha preferência por uma sala pequena onde eu realmente juntava, colava as carteiras na parede, tinha uma quantidade de carteira suficiente pros alunos, não sobrava carteira, então a sala ficava numa forma que o chão ficava livre e não tinha nada atrapalhando pra traz, a compensação tava ali no chão e ali eu gosto de trabalhar. Mas agora eles mudaram as carteiras, colocaram cadeira e mesa, então eu não posso fazer isso, fazer essa movimentação não dá. Já briguei bastante por causa disso, porque não foi em nenhum momento consultado o professor, os alunos se eles querem trabalhar com aquela forma, com aquele tipo de carteira, que pra muitos é extremamente desconfortável. (Renata, 39 anos professora do Ensino Médio)

Renata valoriza um mobiliário de qualidade e que seja fácil de ser movimentado em sala de aula, mas suas ânsias não são atendidas. Por suas falas, percebe-se que ela tem a noção, consciente ou não, que a materialidade educa. 
O mobiliário constitui um dos itens obrigatórios de organização do espaço escolar, que lhe garantem certa uniformização estética se pensarmos nas peças que o compões: carteiras, cadeiras ou bancos, mesa do professor, armários... Mas, por certo, a origem, a matéria-prima, o design são ingredientes que vão diferenciando um ambiente do outro, estabelecendo certa hierarquia material e social (SILVA; JESUS; FERBER, 2012, p. 156-7).

Voltando as falas dos professores:

E nesse caso, como sou doutor em educação e ciência, vou acompanhando a educação em ciências, esse avanço que tá havendo mas, infelizmente, a pressão sobre o valor, o produto pedagógico, o valor de conhecimento que os pais esperam que os alunos tenham torna muito difícil você fazer atividades que não sejam aquela da classe tradicional porque os conteúdos são tão... digamos o currículo imposto, tradicional, imposto ainda pelos vestibulares tradicionais. (Eduardo, 50 anos, professor do Ensino Médio)

Eduardo relata a imposição dos pais e dos vestibulares tradicionais no trabalho docente, o que para ele restringe novas formas de trabalhar o conteúdo e consequentemente restringe a liberdade de o professor exercer suas atividades da forma que acha mais adequada.

A seguir estão transcritos alguns relatos dos professores sobre imposições feitas pela direção de suas instituições de ensino.

Aí depois quando eu entrei para a escola em que dou aula hoje a gente pegou, peguei um novo momento de modificação porque eu entrei na escola com poucos espaços também. A quadra era aberta, no cimento, então os alunos se machucavam muito, era difícil ter um 'espacinho' de areia, até tinham árvores. Ai tira árvore e coloca mais cimento pra fazer um outro prédio pra abrigar mais alunos em sala de aula e não uma nova quadra... Então essas contradições assim, a gente sempre na vida, tem que fazer escolhas e você abre uma janela, abre uma porta, fecha e assim você vai reconstruindo, não tem jeito. Eu peguei a reforma dessa escola que cobriu a quadra. Aí resolve o problema da chuva, mas a acústica péssima, né, o calor é péssimo.

Até hoje, desde a época que eu fui chefe de departamento, que eu fui chefe do departamento de educação física, eu venho pedindo a melhora daquela quadra porque já temos uns quatro casos de calo nas cordas vocais dos professores por conta da estrutura que a gente tem. $O$ professor substituto entra ali $e$ acaba doente por conta da estrutura.

São duas quadras. Aí tem um professor gritando com 30 alunos de um lado e mais um outro aqui gritando.

Então ao mesmo tempo em que a direção tem uma abertura pra fazer coisas novas e pra fazer a estrutura, eles são muito apegados às estruturas, às vezes eu acho que o pedagógico tá aquém do desenvolvimento estrutural [para a direçãol da 
aparência física mesmo, eles acabam se perdendo fazendo tudo acelerado, então não escuta adequadamente o departamento, os professores que vão lidar com aquele espaço. Então em alguns momentos, eu e o meu vice da época, a gente ficava super ligado 'Não espera aí, mas e o projeto? Não, mas a gente precisa dar uma conferida, a gente precisa ver o tamanho'. $\underline{E}$ às vezes a coisa chegava pronta, então como chegava pronta porque o engenheiro falou que era melhor. Eu não sei, não sou formada na área, mas às vezes quem lida no cotidiano sabe levantar os problemas que ás vezes o engenheiro que tem uma formação não sabe. (Mariana, 37 anos, professora do Ensino Médio).

Mariana relata imposições feitas durante a reforma das quadras pela diretoria e até por engenheiros que não conhecem o cotidiano escolar. Além disso, podemos perceber indícios da concepção de educação da instituição de ensino onde Mariana ministra aulas que parece privilegiar ou só valorizar o ensino/aprendizagem dentro de sala de aula, pois acaba com espaços abertos para a construção de mais salas de aula.

E tem que ter identidade. Tem que saber o que é História, o que é Matemática, Geografia, quer dizer, eles precisam dialogar pra fazer essa identidade curricular. E aí esse diálogo não rola. Ou seja, a escola também não tá muito disposta a se abrir pra isso também. Então assim, precisa pensar isso? Precisa. Pensar em um espaço escolar sem pensar no aluno, sem ouvir o aluno é também muito grave. E isso tá sendo feito aqui. $E^{\prime}$ uma proposta de transformar esse espaço aqui ${ }^{26} \mathrm{em}$ sala de aula e aqui em cima também. (Gustavo, 40 anos, professor do Ensino Médio)

Gustavo aponta as determinações da diretoria que constrói e reforma espaços sem escutar professores e alunos, além de não possibilitar discussões sobre o currículo.

A fala de Gustavo demonstra certo fechamento da diretoria em dialogar com os professores e alunos sobre suas preferências. O mesmo acontece com Pedro, que na fala a seguir, demonstra preferência por determinado estilo de sala de aula, mas não pode sempre exercer seu trabalho como professor nesse local por decisões da diretoria.

$E$, acho que, por exemplo, lá no campus prático comparando com o campus daqui. Aqui as salas de aulas são bem normais,

\footnotetext{
${ }^{26} \mathrm{O}$ espaço mencionado pelo professor na entrevista é uma área aberta onde ficam grandes mesas com bancos. Esse espaço é utilizado pelos alunos para bate papos durante o horário do recreio, para fazer trabalhos em grupo. Muitas vezes esse espaço é utilizados pelos professores como uma alternativa à sala de aula, quando quer ministrar uma aula diferente.
} 
salas retas com carteiras enfileiras, quadro negro, o quadro né. Lá tem o quadro, só que é em plateia, então fica mais fácil de você visualizar o aluno, você consegue, você mesmo acaba ficando mais a vontade pra andar e por aí vai. Então acho que fico mais a vontade, mas não podemos escolher dar aulas só nessa sala tipo plateia. Outra coisa, a direção não escuta nossas ideias. Por exemplo, aqui a gente fala: na Faculdade de Gastronomia, você podia ter uma horta pra aluno visitar $e$ diminuir o custo com a compras de alimentos, tem um monte de ideia que dá pra acontecer, mas simplesmente não executam... (Pedro, 33 anos, professor de Ensino Superior)

Já Adriano expõe, na fala abaixo, prescrições governamentais sobre o número de alunos em sala de aula que quando não cumpridas, gera sanções para a escola. Essa política que determina o cálculo do número de alunos em sala de aula não leva em conta as particularidades de cada instituição de ensino, nem os problemas que podem ser gerados para o cotidiano escolar e o ensinoaprendizagem.

Essa era uma briga no [colégio] sempre, por ser uma escola federal a gente tinha possibilidade de diminuir lo número de alunos], eu sempre argumentei que no máximo 25 alunos. $O$ [colégio], o governo agora tá com uma política péssima de calcular o número de alunos da escola pelo número de professores, em função disso ele estabeleceu uma média, e a média, se eu não me engano, é 35 alunos. Se essa média for menor não libera vaga de professor pra aquela escola, então isso fazia com que o [colégio] tivesse salas grandes e aí tinham problemas, por exemplo, nós tínhamos uma retenção no $6^{\circ}$ ano, então os alunos do $5^{\circ}$ ano, 30, 35 alunos, esses 35 alunos passavam porque não tinha retenção no $5^{\circ}$ ano, só que tinha muito no $6^{\circ}$ ano. Então se você tivesse 15 reprovações no $6^{\circ}$ ano isso significava 40, $42 \mathrm{em}$ cada turma e a de $7^{\circ}$ ano com menos, com 28, 27 e eu sempre argumentava: 'Deixa o $7^{\circ}$ ano com 27...', e não, tem que abrir vaga porque é escola pública e aí a qualidade sempre era prejudicada de fato. (Adriano, 44 anos, professor de Ensino Superior)

Uma das características do trabalho docente é a autonomia ${ }^{27}$. Essas imposições relegam o trabalho do professor a um segundo plano.

Os relatos dos professores demonstram certa perda (ou inexistência) da autonomia em relação à escolha do mobiliário escolar e escolha do espaço. "Esta

\footnotetext{
${ }^{27}$ Falo em autonomia como uma emancipação, certa independência nas escolhas, como um processo coletivo e ao mesmo tempo individual, como a possibilidade de eleger como melhor exercer o seu trabalho, como a percepção de que a homogeneização não implica necessariamente em uma igualdade.
} 
falta de autonomia do professorado coloca em dúvida a existência de uma ‘profissão' docente” (LÜDK; BOING, 2004, p. 1173-4).

Certeau (1994, p.38) afirma que o cotidiano "se inventa com mil maneiras de caça não autorizada", isto é, as pessoas criam diferentes formas para viver a ordem social das coisas, têm a possibilidade de encontrar fugas para não se submeter à violência do cotidiano, do social e abrir os próprios caminhos para alterar as práticas e os códigos. Por que então esse professores, mesmo de escolas e níveis de ensino diferentes, relatam tamanha subordinação? Isto ocorre porque os professores se sentem aprisionados por imposições que estão além de suas escolhas, como as decisões da diretoria sobre o mobiliário escolar, escolha da sala de aula e a determinação curricular, mesmo que implícita, ocasionada pelos exames de acesso à universidade.

\subsection{Público x Privado ${ }^{28}$}

Alguns professores fizeram comparações entre infraestrutura de escola pública e particular e como isso influenciou na sua formação, na sua vivência como aluno e, também, como influencia no ser professor.

Mariana fala de sua graduação em uma faculdade particular: "Eu sempre passei por processos, processos mesmo de reconstrução das coisas, quando eu entrei na graduação a gente tinha duas salas, pequenas, aí quebrava a lâmpada. Funcionando ou não funcionando a lâmpada a gente ficava tendo aula no escuro. Uma bolha, a gente chamava bolha, era uma quadra que ficava dentro de uma lona fechada que a gente ia e era uma quadra assim, uma bolha. Também tinha alguns espaços abertos. Aí tu imagina fazer uma formação onde você não tem uma infraestrutura, então já começa a limitar a tua própria formação porque você não sabe dar uma aula de atletismo, você até vê lá umas coisas que foram adaptadas, mas você não tem o espaço, a pista, aí não tinha natação, aí de vez.

\footnotetext{
${ }^{28}$ Encontrei esse mesmo tipo de comparação na minha pesquisa de mestrado (Percepções e Vivências do Espaço na EJA:'Em zigue-zague, chegar ao final do corredor' - 2010) sobre EJA e espaço escolar que realizei em uma escola particular de Juiz de Fora que fornecia um curso gratuito de EJA da segunda etapa do Ensino Fundamental até a conclusão do Ensino Médio. O interessante é que os alunos achavam a escola particular mais produtiva, principalmente por causa de sua infraestrutura, comprometimento dos professores e principalmente pela disciplina, que para eles era fator primordial para o sucesso educacional. Já os professores gostavam mais de ministrar aulas em escolas particulares por causa da infraestrutura e pelo impacto que um espaço bem cuidado e com regras causava nos alunos.
} 
em quando a gente passava 1 mês tendo aula num clube, era tudo assim” (Mariana, 37 anos, professora do Ensino Médio)

Mariana fala de sua experiência enquanto professora em escola pública:

Agora, hoje se eu for olhar pra todas as escolas públicas, não condiz, então imagino que qualquer professor de qualquer licenciatura, que se formou, na UFJF ele vai ter uma formação boa, mas ele tem uma ilusão de que ele vai ter facilidade pra trabalhar no ensino fundamental e médio aí a realidade é outra, ele vai ter que fazer mil adaptações. É uma outra graduação, a graduação da vida. Ele vai ter que ter um saber experiencial ali, conversar com pessoas, assistir aula de outras pessoas pra se reconstruir, porque colocar em prática o que ele aprendeu na teoria, teoria e prática da graduação, ele não consegue chegar lá e passar, pois o espaço da escola pública não permite. (Mariana, 37 anos, professora do Ensino Médio)

Pela descrição de Mariana percebemos que existiam problemas de infraestrutura tanto em uma faculdade particular, quanto em colégios públicos onde ministrou aulas. Nesse sentido, a comparação público x particular, não pode ser realizada de forma genérica e generalizada.

Julio fala de sua experiência enquanto aluno comparando escola pública e particular:

Fiz o fundamental em uma escola particular. O Médio, que era $o$ científico, fiz parte em escola privada e depois fui pra pública. A estrutura em si era muito diferente, muito diferente. $O$ convívio social também com as relações interpessoais também era bem diferente porque eram pessoas que vem de outra realidade.

$\mathrm{Na}$ escola particular que eu estudava tinha estrutura de quadra, biblioteca, lanchonete, piscina pra fazer natação, toda a estrutura da rede privada mesmo, né, mais o que tem de benefício, eventos, atividades, ao passo que na estrutura pública não tinha nada disso, as quadras eram precárias, tudo era feio, sujo. $O$ comportamento também da parte dos alunos da rede privada era diferente, havia um certo cuidado nas relações interpessoais ao passo que na rede pública eram mais agressivos, tinham comportamentos diferentes tipo, matar aula, pular muro...

Eu acho que influenciou negativamente sim a minha relação com a escola.

Existia uma diferença dos professores. Os professores da rede particular eram mais exigentes. E da rede pública eram mais tipo "laissez faire laissez passe", eles eram mais tranquilos eu acho que até mesmo pela própria realidade de ficar insistindo. Hoje eu sendo professor eu vejo o quanto você tem que persistir pra poder formar, até mesmo o caráter, até mesmo... Essa questão de formar o cidadão, não só enquanto profissional, 
mas também enquanto pessoa, isso é muito difícil. (Julio, 34 anos, professor de Ensino Superior)

No relato acima, Julio traz outros dois paradigmas $^{29}$ muito comuns utilizados na comparação entre escola pública x privada: o comportamento dos alunos e grau de exigência do professor. Para ele, os alunos da escola pública com os quais ele conviveu tinham um comportamento desviante do que ele achava correto, eram mais indisciplinados do que as estudantes de escola particular. Já os professores da rede privada que ele frequentou são mais exigentes do que os da escola pública.

Julio aponta que a disciplina dos alunos na escola pública era pior do que na escola particular e isso o influenciou negativamente. Dessa forma, para Julio a disciplina transforma-se em parâmetro de qualidade do trabalho docente, de sucesso no processo ensino-aprendizagem e de empenho do aluno com sua educação.

Julio fala de sua experiência enquanto professor em uma instituição particular:

Já é um fator, na realidade isso aí, um espaço que tem um aspecto limpo, organizado, isso eu acho que em qualquer estância, em qualquer área da sua vida, a organização é primordial, então se você chega em casa e a sua casa tá bem organizada, limpa, tudo no lugar, você se sente bem, você dorme tranquilo. Então fazendo analogia, em sala de aula é da mesma forma, então você tem um ambiente limpo, organizado, uma cadeira confortável, uma carteira pra você colocar seu material pra você poder estudar, no mínimo se tem ventilação, se tem ar condicionado, se tem iluminação adequada, isso tudo é... Aqui, por exemplo, eu não sinto essa diferença em outras instituições porque eu dou aula em instituição particular então isso é muito cobrado, então os alunos, o próprio mercado muito competitivo faz com que as instituições se adequem a essa norma de conforto básico e ainda vão para além disso. (Julio, 34 anos, professor de Ensino Superior)

A concepção de espaço como algo físico perpassa o relato de Julio, mas demonstra indícios da percepção do lado simbólico das espacialidades. Ele dá muito valor à infraestrutura e ao conforto ambiental da sala de aula. Ele generaliza a discussão escola pública x particular, pois acredita que a infraestrutura das duas

\footnotetext{
${ }^{29}$ Nas entrevistas que fiz com os alunos de EJA para a minha pesquisa de mestrado esse tipo de comparação - alunos da escola pública serem mais indisciplinados e menos interessados do que os estudantes de escola particular e os professores da rede privada serem mais exigentes - apareceu na fala de todos os entrevistados.
} 
instituições $^{30}$ de ensino superior onde leciona se repete em todas as outras particulares.

Raquel fala de sua experiência na graduação em uma universidade pública: $O$ espaço é sempre muito depredado, o que me incomodava. Na universidade pra mim... Eu acho que o espaço tem que ter um aconchego, a gente tinha que ter esse aconchego e a gente sentar numa carteira rabiscada, quebrada, às vezes tem que trocar uma carteira e isso não incomodar ninguém, sabe. Uma sala que não tenha uma caneta, você olha pro quadro e vê um buraco no meio do quadro. Foi essa a minha faculdade de filosofia. A gente vê o abandono com $o$ local e isso traz pra gente, sei lá, uma desesperança, pra que educação? Um espaço pra educação desse jeito... Não deveria ser um espaço educativo? Quem depreda é a gente mesmo, mas porque a gente depreda e porque continua a depredar e porque ninguém se importa com isso? Os professores não se importam com isso. Me incomodava bastante. (Raquel, 48 anos, professora do Ensino Médio).

Raquel fala de sua experiência enquanto professora em uma instituição pública:

Talvez seja por isso [pelo que sentia em relação ao espaço depredado da faculdade] que depois eu fui fazer parte de um projeto que, na minha concepção, é um projeto que não tem nada a ver, tanto que eu fiz tudo diferente, que é o tal do $5 S^{31}$ [em uma instituição de ensino pública]. Eu caí de paraquedas nesse programa. A minha coordenação tinha que encaminhar um professor, eu tava chegando da minha licença maternidade... Quem que mandaram? Eu né! E fui fazer parte desse grupo 5S, cheguei lá tinha um monte de técnica, um monte disso, de peixe ${ }^{32}$, não sei o que. Um monte de coisa que eu falei: 'eu nem sei por que estou aqui! Eu nunca fui uma pessoa que...'. Eu não sei trabalhar com muita programação. $E u$ trabalho com aquilo que acontece, com aquilo que é possível, isso sou eu. É a minha vida, minha vida é assim. Então eu não conseguia trabalhar com aquela coisa toda rígida e eu caí na coordenação disso, só que aí o que eu fiz, fiz tudo diferente. Do meu jeito, do meu ver, ficou com aquele nome lá de 5S, mas eu não fazia a técnica, eu nem sei o nome do que eu

\footnotetext{
${ }^{30}$ Julio leciona em duas Faculdades particulares de tradição no município, estabelecidas na cidade a mais de 40 anos, são faculdades sólidas e bem avaliadas pelo MEC.

${ }^{31} \mathrm{O}$ programa 5S é a etapa inicial para a implantação da 'Qualidade Total'. é assim chamado devido a primeira letra de 5 palavras japonesas que são a base desse programa: Seiri (utilização), Seiton (arrumação), Seiso (limpeza), Seiketsu (normalizar) e Shitsuke (disciplina). Pela fala de Raquel, a proposta de implantação do programa 5S na instituição de ensino foi uma imposição da diretoria, mas não foram dadas explicações do que é o programa e como seria implantá-lo.

32 Quando Raquel se refere a peixe, é o diagrama espinha de peixe ou diagrama de causa e efeito. É uma ferramenta gráfica utilizada para apontar prováveis causas de problemas e assim pensar em soluções. As causas são pensadas a partir do método, material, mão de obra, maquinário, medida (instrumentos) e meio ambiente.
} 
fazia ali. Eu juntava alunos e ia fazer campanhas mesmo, ia gritar no colégio. A gente conseguiu oito anos de um colégio bem pintado, sem uma necessidade de manutenção por depredação, só por desgaste. Então, eu sempre gostei um pouco de um ambiente mais organizado, mais limpinho, sempre gostei mais disso. Então a mim incomodava a sala de aula da universidade, me incomodava bastante. [...] Tem uma ou outra mudança lá, agora eu não estou lá vendo, mas não tem mais esse cuidado todo. (Raquel, 48 anos, professora do Ensino Médio)

Raquel percebe que o espaço escolar vai além do espaço físico, que ele é multifacetado, tem valores simbólicos, educativo e afetivo. Ela também compreende que para que isso aconteça os habitantes do espaço escolar têm que se sentirem pertencentes a esse espaço. Nesse sentido, existe uma diferença entre saber-se pertencente ao espaço escolar e sentir-se pertencente ao espaço escolar. Você sabe que pertence a um espaço porque falam isso para você, porque você passou em alguma avaliação que te permitiu frequentar esse espaço. Sentir-se pertencente vai além disso. Sentir-se pertencente ao espaço escolar acontece quando existe a percepção de que a escola te acolhe, socializa o bem estar, escuta sua opinião e te integra nas decisões. Quando o aluno se sente pertencente ao espaço escolar ele não o depreda.

Leonardo fala da diferença que sentiu quando passou de uma escola pública da região rural de Pernambuco, para outra escola pública do interior de Minas Gerais: "Em Minas a escola era muito organizada, muito limpa, a merenda era muito boa e eu lembro que tinha moral cívica, então semanalmente a gente se reunia no pátio para cantar o hino Nacional. Tinha uma rigidez da diretora muito grande, mas era uma pessoa que eu admirava, eu achava ela muito correta. As salas eram todas iguais, eram carteiras em fila, não tinha nada de muito diferente não. Mas eu lembro que era um espaço muito bem organizado, muito mais do que as escolas anteriores [no interior de Pernambuco] que eu tinha passado. (Leonardo, 41 anos, professor do Ensino Médio)

Leonardo faz a comparação entre escolas públicas de estados diferentes: Minas e Pernambuco. Pela fala de Leonardo, mais uma vez podemos perceber que a discussão entre escolas públicas e privadas não pode ser realizada de forma genérica e generalizada, principalmente a respeito do espaço escolar, que possuí características relacionais.

Leonardo fala de sua experiência na graduação em uma universidade pública: 
$E$ E, o Instituto de Ciências Humanas (ICHL $)^{33}$ não era tão bem cuidado, mas eu adorava aquele espaço. A sala de aula internamente não era bonita. Achava elas meio escuras, as carteiras meio depredadas, não tinha facilidade pra obtenção de... Se a gente fosse apresentar um trabalho, não tinha um Datashow, o computador era antiguidade, o espaço da informática era muito precário na época, os computadores eram muito... Também era 98, isso quantos anos atrás! Mas eu adorava, passava o dia inteiro lá. A cantina era um lugar muito bom de ficar também. Foi onde de fato eu me encontrei como aluno. (Leonardo, 41 anos, professor do Ensino Médio)

Leonardo provavelmente se sentia pertencente ao espaço do ICHL, percebia o descuido com a manutenção, mas criou um sentimento afetivo com o lugar.

Leonardo fala de sua experiência profissional comparando escolas particulares com públicas onde ministrou aulas:

As escolas particulares que eu trabalhei eram escolas boas com uma boa infraestrutura, principalmente [uma escola de elite do município], então era um espaço muito bom. Então assim, facilitava o uso de recursos, a disposição das carteiras, elas não ficavam muito juntas, elas tinham lugar pra guardar material, eram novas e limpas... Eu acho que uma sala apertada com carteiras muito próximas, eu acho que piora, a animosidade aumenta, é um que esbarra no outro, não dá certo. Então assim, uma coisa que me incomoda muito, incomoda um professor, sala muitos pequenas e muito quentes. Os ventiladores muito próximos, muito barulho de ventilador, alunos muito apertados... Isso me incomoda muito e isso eu encontrei em escola pública.

Eu acho que uma sala mais ampla, ela precisa ser mais ampla do que bonita. Tem que ter mais espaço, ventilação, luminosidade. Um bom quadro é fundamental, espaço interno pra guardas material de aluno. É diferente quando ele tem armário, isso ajuda muito na dinâmica da escola. (Leonardo, 41 anos, professor do Ensino Médio)

Leonardo faz uma comparação entre as escolas particulares e públicas onde lecionou. A escola particular que ele menciona é uma escola de elite e prestígio na cidade, onde a infraestrutura é muito superior à maioria das escolas particulares e públicas da cidade. Além disso, ele evidencia suas preferências de tamanho de

${ }^{33} \mathrm{O}$ Instituto de ciências Humanas dessa instituição de ensino superior é o mesmo que foi frequentado por Raquel. Mesmo espaço e sentimentos diferentes. Penso que essas diferenças ocorram pela história de vida dos dois professores. Raquel sempre estudou em escolas bem cuidadas, já Leonardo tinha outra vivência, por isso outro parâmetro de comparação, como percebemos na fala de Leonardo: "Na escola tinha muito carência, era região rural de Pernambuco. Se hoje não é bom, imagina na minha época! Mas eu gostava da escola, principalmente da merenda [...]. Eu lembro também de umas sopas que eu tomava nas canequinhas assim. Então eu não sei, pela dificuldade que a minha família passou, assim, de não ter mesmo alimento em casa, muita precariedade, eu acho que a merenda tinha um peso grande pra mim". 
sala, equipamentos e mobiliário escolar, mas da forma como ele expõe, mostra indícios de que esse tipo de infraestrutura só é alcançado em escolas particulares, e também que é algo difícil de modificar nas escolas que não apresentam esse tipo de ambiente ou mobiliário.

O imaginário positivo constituído sobre a escola particular é um discurso que perpassa por todos os setores da sociedade brasileira. Esse discurso é construído por uma oposição à escola pública, a uma suposta superioridade da escola privada que é difundida quase sem contestação por ser naturalizada. Mas é um discurso que não tem fundamento, pois não existe um só modelo de escola pública, muito menos de escola particular.

No caso dos professores entrevistados, a infraestrutura e o espaço bem cuidado e planejado da escola particular são associados a algo positivo e sua falta é percebida como um dificultador do trabalho docente e do ensino-aprendizagem. Nessa perspectiva, a escola particular, em comparação com a pública, é um lugar onde é mais fácil de trabalhar, pois se tem melhor acesso à tecnologia e a uma infraestrutura de melhor qualidade. Entretanto, Mariana teve uma experiência negativa em uma faculdade particular, da mesma forma que essa experiência se repete enquanto professora em escolas públicas.

De acordo com Brandão (1985), os resultados obtidos pelo aluno de escola privada $^{34}$ se devem mais à família, pois a educação dos pais é mais próxima da educação escolar, além dos pais mobilizarem recursos como reforço escolar, atendimentos especializados sempre que necessário para o bom desempenho de seus filhos.

Raquel demonstra um incômodo com o espaço depredado da universidade pública, principalmente por ser um espaço educacional.

Entendemos que a materialidade educa: constrói posturas, gostos, valores estéticos, sentimentos de pertença. Assim, as diferenças na forma de dispor socialmente esta materialidade também se colocam como elementos que educam. (SILVA; JESUS; FERBER, 2012, p.165)

Já Leonardo, por ter vivências diferentes não teve problema em se adaptar nesse espaço. Os dois acabam levantando uma discussão comum à Arquitetura: forma x função. Para Leonardo, é mais importante o lado funcional do espaço " $E u$ acho que uma sala mais ampla, ela precisa ser mais ampla do que bonito”. Já

\footnotetext{
${ }^{34}$ Acredito que atualmente isso ocorra mais em escolas particulares de elite.
} 
para Raquel, a forma é essencial "eu sempre gostei um pouco de um ambiente mais organizado"; "Eu acho que o espaço tem que ter um aconchego". A meu ver, os dois professores têm razão nas suas revindicações.

Forma (estética, aspecto do espaço) e função (atendimento a um conjunto de necessidades) andam juntas na Arquitetura. São indissociáveis, algumas vezes uma se sobrepõe a outra dependendo do olhar do arquiteto ou das necessidades e preferências do usuário. Mas, prefiro concordar com Coelho Netto (2009) e pensar que a dicotomia forma e função deveria ser substituída pelo trinômio belo/comodidade/humanidade, que abarcaria todas as características da espacialidade: física, simbólica e relacional.

\subsection{Cheio ou vazio: questão de percepção}

No grupo de professores entrevistados, parte prefere dar aulas para um número grande de alunos e outra parte prefere um grupo menor, o interessante também é a percepção do que são muitos ou poucos alunos.

Olha, eu acho muito mais difícil trabalhar com seis do que trabalhar com sessenta. A sensação que eu tenho é que a turma de sessenta te impulsiona mais. Normalmente é o que eu quero. Uma turma pequena geralmente é uma turma menos motivada. Não quero padronizar, mas normalmente o que eu observo na faculdade é isso. Parece que isso gera uma apatia, sabe? Em um, no outro e aquilo traz toda uma série... É uma cadeia, se você tem um aluno que não te motiva, você passa a ser um professor que não motiva o aluno e isso vira um ciclo. A turma com sessenta, você tem uma diversidade maior então eu acho que... Eu sempre gostei muito de trabalhar com adolescente pela questão do desafio, então uma turma com sessenta te traz mais desafio. Você vai para a sala com uma cabeça diferente, você fala assim: 'Eu tenho que estar ali, eu tenho que passar informações e esses meninos tem que estar com a cabeça aberta para poder absorver essas informações', então o desafio eu percebo que é maior e isso eu gosto mais. (Erica, 37 anos, professora de Ensino Superior)

Eu prefiro sala cheia. Porque eu dou aula em algumas turmas que eu tenho 10, 6 alunos. Turma de 20 pessoas que às vezes vão 6, vão 5, é desmotivante, você acaba pensando assim que você vai ter que fatidicamente voltar com o conteúdo porque mais de $70 \%$ da turma não está presente, então isso estressa 
um pouco. Então acho que sala cheia é melhor e mais produtiva. 40 é um bom número. (Julio, 34 anos, professor de Ensino Superior)

Erica e Julio se sentem mais motivados quando a sala de aula está cheia de alunos. Entre os professores entrevistados eles são exceção.

Então eu fiz a minha primeira faculdade foi numa escola particular com 240 alunos, foi muito difícil porque o professor era muito distante o tempo inteiro. A gente tinha muito pouco acesso ao professor e era permitido fumar dentro da sala, então eu sempre tive alergia e quando eu fiquei grávida era impossível frequentar em determinados momentos a aula, então eu tive que faltar muito na época. [...]Sempre dei aulas de informática para turmas divididas, pois usava laboratório. Então eram 15 alunos. Achava um bom número, levando em conta a especificidade da disciplina. Já na Filosofia trabalho com turmas inteiras, com 35 alunos. Não gosto, pois dificulta muito os debates e ajuda na dispersão. Acho que, nesse caso, entre 15 e 20 alunos é o ideal.. (Raquel, 48 anos, professora do Ensino Médio)

Nós temos períodos em que as turmas são divididas e nós temos 20 alunos. Apesar de uma cozinha menor, 20 alunos funciona muito mais, é muito mais interessante, você fica muito mais próximo do aluno, é um conhecimento muito mais acompanhado do que nos períodos subsequentes que são o $3^{\circ} \mathrm{e}$ $4^{o}$ que é onde nós temos 34, 35 alunos dentro de um único ambiente pra atividade prática é mais complicado. Pra teórica também faz diferença. As turmas que estão juntas com 40, 45, 35, 37, isso dificulta um pouco a aula expositiva porque os alunos ficam impacientes, são muitos, muitas vezes eles não ouvem direito o que você está falando. (Eliana, 38 anos, professora de Ensino Superior)

Eu como professor de física tenho um certo privilégio que também é um compromisso de ter semanalmente a possibilidade de dividir a turma em dois, junto com o professor de química. E isso pra fazer trabalhos de laboratório, ou na sala de informática ou mesmo trabalho em grupo, porque daí... Os 30 alunos, nossa escola trabalha em torno de 30-32 alunos. Então a gente fica com 15,16 e a gente e pode fazer um trabalho bastante diferenciado porque um trabalho de laboratório com 30 alunos pra um professor só em 50 minutos é impossível. (Eduardo, 50 anos, professor do Ensino Médio)

Raquel, Eliana e Eduardo preferem sala com menos alunos, pois acreditam que assim conseguem uma melhor relação professor-aluno. Raquel expõe sua experiência enquanto aluna da faculdade de Direito em salas de aula com 240 estudantes, onde não conseguiu fazer amizades e nem se conectar com os professores. Ela ainda aponta que existe um número de alunos por classe ideal 
para cada disciplina. Aqui, mais uma vez aparece o sentimento de imposição do conteúdo da disciplina sobre o espaço escolar.

Eu acho que faz toda diferença o número de alunos em sala de aula... Eu acho que assim, o aluno geralmente ele não exterioriza a dificuldade dele publicamente, ele te fala se você for, eu circulo propositadamente, porque você chega e olha e ele te fala, aquele que não quer ou que não gosta ele não vai fazer de jeito nenhum, mas o que quer mas está com alguma dificuldade, ele te fala se você dá essa oportunidade pra ele. Eu acho que se o número de alunos fosse menor eles [os alunos] seriam mais produtivos sim. (Renata, 39 anos, professora do Ensino Médio)

Sim, que assim, ano passado eu dei aula pro $6^{\circ}$ ano, eram 30 alunos, a média 30 aqui, eu tinha a impressão que 30 alunos era demais, pro $6^{\circ}$ ano, eu acho que professor pro $6^{\circ}$ ano tem que ser só no $6^{\circ}$ ano, te aula em lugar mais nenhum que ele ocupa a sua mente de um jeito que é um desgaste muito grande e 30 eu acho demais. A demanda é muito grande. Lá no $3^{\circ}, 30$ dá, entendeu? Pelo grau de maturidade deles. (Gustavo, 40 anos, professor do Ensino Médio)

Acho que tem uma coisa horrorosa no Brasil que é isso, eu e você temos que dar aula pra 40 alunos. Eu posso ser um professor que eu prendo 100 alunos, que eu consigo dar aula pra 100 alunos. Você pode ser um professor que não consegue dar aula pra mais de 10. Porque que nós temos que dar aula pro mesmo número de alunos? Você tem isso efetivamente na escola. Tinha uma professora de ciências num colégio que eu trabalhei que você via ela com 5 alunos e os alunos adorando e ela adorando, você colocava ela com 30, era um terror, ela não consegue dar aula pra 30. A história dela é com menos. Você tinha professor nesse mesmo colégio que dava aula pra 50 e todo mundo prestava atenção, então eu acho que depende do professor sim, mas acho que tem que diferir essa coisa homogênea todo professor tem que dar aula pra uma turma de 40 alunos e isso é péssimo. Isso é muito ruim. (Adriano, 44 anos, professor de Ensino Superior)

Renata, Gustavo e Adriano apresentam uma visão mais crítica do que é sala cheia ou vazia. Para eles cada caso é um caso, sem padronização. Para Renata, o número de alunos em sala de aula influência mais os alunos, principalmente o aluno que é tímido. Já para Gustavo, o número de alunos depende da etapa e ano de ensino. Adriano questiona o porquê da padronização, que deveria ser escolha do professor a quantidade de discentes em sua sala de aula.

Como determinar e medir as dimensões físicas e relacionais do espaço humano que é a sala de aula, que se torna ampla ou reduzida dependendo de 
preferências, experiências e vivências de seus habitantes? O que significa cheio e vazio? Por que essas diferenças de preferência? Para tentar problematizar essas questões, utilizo como inspiração discussões sobre 'binários de referencial ideológico ou filosófico', 'a dialética dos binários' como amplo x restrito de Coelho Netto (2009) e interno x externo de Bachelard (2008).

De acordo com Foucault (2007, p.325), “a historicidade poderá introduzir-se na espessura da própria palavra". Nessa perspectiva, uma palavra pode ser polissêmica dependendo da época, local e situação em que é empregada. Atribuímos a esses binários poderes de determinação ontológica, como se eles fossem opostos perfeitos.

Entre o concreto e o vasto, a oposição não é clara. Ao menor toque, porém, a dissimetria aparece. E é sempre assim: o interior e o exterior não recebem do mesmo modo os qualitativos, esses qualitativos que são a medida da nossa adesão às coisas. (BACHELARD, 208, p.219)

Bachelard (2008) aponta que a imensidão é uma categoria filosófica. O devaneio é imensidão, mas a prática é o restrito. "A amplidão exibe o poder de seu possuidor" (COELHO NETTO, 2009, p. 65). Nesse sentido, o sujeito pode perceber um espaço como algo que não domina, pois não pode preenchê-lo ou entende como algo previamente preenchido, de algo que não entende ou algo que não possa manipular. "Na verdade, assim, a imensidão é tão misteriosa quanto o restrito [...]; tão habitada por fantasmas quanto o espaço reduzido" (COELHO NETTO, 2009, p. 65).

A relação interior e exterior encontra-se em todo edifício construído pelo homem e possibilita diferentes sensações, desde confinamento, passando pelo sentimento de proteção até o de exposição excessiva.

$\mathrm{O}$ exterior e o interior formam uma dialética de esquartejamento, e a geometria evidente dessa dialética nos cega tão logo a introduzimos em âmbito metafórico. Ela tem a nitidez crucial da dialética do sim e do não, que tudo decide. Fazemos dela, sem o percebermos, uma base de imagens que comandam todos os pensamentos do positivo e do negativo (BACHELARD, 2008, p.215).

Nessa perspectiva, esses termos aparentemente contraditórios, são polissêmicos e suas interpretações dependem das diversas relações espaciais vividas.

Embora sejam muito diferentes entre si, os referentes ideológicos entram na composição de sistemas de significação e ação que se manifestam na dinâmica da paisagem. Observados um por um, esses referentes ideológicos parecem 
frequentemente contraditórios. Observados dois a dois, agem como forças opostas nas quais o indivíduo procura se situar. Na prática essas polaridades se equilibram em seus efeitos ou então permitem a mudança pela predominância relativa uma sobre a outra (BERDOULAY, 2012, p. 114).

É o espaço escolar e as vivências anteriores dos professores que permitem a compreensão da interdependência da polaridade do referencial ideológico ou filosófico cheio - vazio. Esse referencial pode se excluir ou se reforçar mutuamente dependendo de ações coletivas ou individualizadas nas quais são pautadas as decisões dos docentes. 


\section{Memórias e Práticas}

O passado, a rigor, é uma realidade absoluta, que só se torna cognoscivel mediante a voz do narrador. (BOSI, 2003, p. 61)

Este capítulo procura perceber e compreender pelas falas dos professores se as vivências do espaço escolar enquanto alunos influenciam de alguma forma suas práticas como profissionais.

Para Bergson (2010), nosso presente é uma extensão de todo nosso conhecimento passado. Nessa perspectiva, quando nos tornamos professores trazemos toda nossa bagagem de vida para nossa prática em sala de aula, mas isso nem sempre é consciente em nós. "Esses repertórios de competências constituem o alicerce sobre o qual vão ser edificados os saberes profissionais durante o resto da carreira" (TARDIFF; RAYMOND, 2000, p. 239). Nessa perspectiva, compreender a percepção espacial dos professores sem inseri-la em suas histórias profissionais e trajetórias educacionais e de formação, fatores que modelam suas identidades profissionais, propiciaria uma análise truncada. Visto como, de acordo com Bergson (2010), as lembranças estão sempre influenciando as percepções atuais. Dessa forma, a percepção não é pura, mas concreta e complexa.

Pela fala dos professores percebemos que muitos utilizam experiências passadas como inspiração para suas práticas docentes.

Porque como todo mundo está ligado na questão desses quatro esportes de quadra, internacionais, porque a gente tem influência de outros países pra trabalhar handball, futsal, volleyball e basquete, então eu fico assim: 'Se já está sendo desenvolvido pelos outros, eu vou fazer as coisas diferentes da cultura [instalada nas escolas sobre que esportes trabalhar na Educação Física] '. Porque aí vem a questão da minha experiência pessoal $^{35}$, então eu gosto de trabalhar jogos, eu trabalho dança, eu trabalho diferentes ginásticas, eu trabalho esportes de outros países que a gente não utiliza na escola, esportes do Brasil... Então agora no $3^{\circ}$ ano do Ensino Médio, eu estou tendo um trabalho com eles que tu não tem noção, porque praticamente nos últimos anos o negócio tava meio

\footnotetext{
${ }^{35}$ A experiência pessoal que a professora Mariana se refere é quando ela estava no Ensino Fundamental e Médio ela queria fazer dança e outras modalidades esportivas e os professores de Educação Física só ensinavam vôlei para as meninas.
} 
solto $^{36}$ e eu penso que esses meninos precisam ter uma outra noção, e aí eu comecei, então eu faço diferente... (Mariana, 37 anos, professora do Ensino Médio)

No caso de Mariana, ela reflete sobre a cultura de utilizar somente os quatro esportes internacionais (handbol, futsal, volei e basquete) e, fundamentada em sua formação e suas experiências pessoais, tenta criar uma forma diferente de abordar esporte nas escolas.

Quando um indivíduo precisa tomar uma decisão, ele se apoia em valores disponíveis em sua cultura: são 'referentes ideológicos'. Eles constituem um reservatório de ideias fundamentais, um conjunto de representações (crenças, valores, pressuposições, atitudes, sensibilidades) que o indivíduo utiliza para justificar ou guiar suas condutas, especialmente diante de situações particulares (BERDOULAY, 2012, p.113-4).

Nessa perspectiva, a memória possui a característica de separar o 'eu' dos outros, de recuperar acontecimentos, tempos, espaços, relações e de conferir significados a essas experiências.

Por muito que se deva à memória coletiva, é o indivíduo que recorda. Ele é o memorizador e das camadas do passado a que tem acesso pode reter objetos que são, para ele, e só para ele, significantes dentro de um tesouro comum. (BOSI, 1994, p. 411)

Eu não circulo em sala de aula como meu professor preferido na faculdade fazia, eu acho que eu até poderia circular. O que eu tenho feito, que eu tenho percebido melhoria na qualidade da minha aula, eu tenho envolvido mais o aluno, antes de passar um slide, antes de falar sobre determinado assunto. Por exemplo, hoje eu falei sobre ciclos de vida de uma empresa, de um estabelecimento gastronômico, antes de chegar, de entrar no assunto, eu perguntava o que a pessoa acha que poderia ser $e$ conduzir [o ciclo de vida de um estabelecimento gastronômico]. E chamo e falo muito e pergunto o que ele pensa, o que ele acha em relação aquilo e isso tem funcionado bastante. Esse é meu natural jeito de dar aulas [...] Na rede privada [quando ele estudava no Ensino Fundamental e parte do Ensino Médio] tinha uma professora que eu não gostava dela, mas depois que passou um tempo, na vida adulta, que eu vim a gostar dela [...] era a professora de português. Ela tinha um perfil sério, não tinha abertura pra brincadeira, ela era uma liderança mais autocrática, ela impunha, ela cobrava, ela arguia... Me baseio um pouco nela. (Julio, 34 anos, professor do Ensino Superior)

\footnotetext{
${ }^{36} \mathrm{O}$ 'trabalho meio solto' que a professora Mariana se refere era que a Educação Física no $3^{\circ}$ ano do Ensino Médio da instituição de ensino onde ela trabalha era uma disciplina que na prática era tratada como opcional: o antigo professor dava uma bola para os alunos, jogava quem queria e quem não queria ficava conversando próximo a quadra. Atualmente a professora Mariana trabalha diferentes tipos de atividades esportivas com os alunos do Ensino Médio. O slack line é um deles.
} 
Julio não repete em sua prática como professor os métodos e didáticas que mais gostava quando era aluno: um professor mais ligado aos alunos, que conversava, contava casos, comentava sobre o que tinha visto no jornal. Ele repete o modelo rígido de sua professora de Português por acreditar que é mais eficiente, embora menos prazeroso para seus alunos. Ao mesmo tempo acredita que tem 'um jeito' próprio de dar aulas e não reconhece que esse 'jeito' foi construído ao longo de sua formação docente.

Quando os professores atribuem o seu saber-ensinar à sua própria "personalidade" ou à sua "arte", parecem estar se esquecendo justamente de que essa personalidade não é forçosamente "natural" ou "inata", mas é, ao contrário, modelada ao longo do tempo por sua própria história de vida e por sua socialização. Além disso, essa naturalização e essa personalização do saber profissional são tão fortes que resultam em práticas frequentemente reprodutoras dos papéis e das rotinas institucionalizadas da escola. (TARDIFF; RAYMOND, 2000, p. 223).

Nas falas que seguem a baixo, a professora Renata narra sua experiência na alfabetização, em que o tipo de vivência do espaço a marcou muito e influencia potencialmente sua prática atual como docente. Fato esse, que ela só percebeu durante a entrevista. Raquel fala de sua experiência enquanto aluna em uma escola diferenciada:

\begin{abstract}
Minha mãe me colocou numa escola, que era muito interessante, que era uma escola de casas de professoras. Era uma escola que parecia... Era no quintal da professora, e eu me lembro disso muito bem. Embora minha idade, né, cinco anos. E aí, ela tinha, era tipo uma cabana de índio, sabe? Era toda de madeirinha e com aquele telhado, né?! Ela era arredondada. Era uma sala de aula, porque era uma professora no quintal da casa dela que dava aula. É... a pré-escola. Mas depois ela teve que mudar desta casa e ela mesma queria continuar com a turma. Aí a gente foi pra igreja. Aí eu fui alfabetizada desse jeito. Com cinco anos, na casa dela. Passamos depois pro salão da igreja, perto da minha casa, mas aprendendo a educação formal.
\end{abstract}

Pergunto se ela sentiu falta da cabana.

É. Eu gostava demais daquela cabana. Porque tinha umas ideias de... era tudo amplo, embora ela seja pequena, mas assim, dentro, as carteira era todas encostadas, naquele espaço redondo. Eu não sei quantos alunos tinham, não deviam ser muitos, mas eu não tenho essa ideia. Mas eu sei que ficava aquele meio. Aquele meio livre, que era onde a gente também fazia brincadeiras, brincadeiras de chão, né?! Então a sala, ao mesmo tempo, ela servia para as duas coisas. A gente tinha que brincar ali, porque o quintal dela estava tomado pela aquela cabana. Então, mas era muito legal e assim... eu lembro do 
rosto da professora. Eu lembro do sorriso. Ela se chamava Sônia. Eu achava muito bacana aquilo. (Raquel, 48 anos, professora do Ensino Médio)

\section{Raquel fala de sua experiência enquanto professora de Informática e porque}

tomou a decisão de se tornar professora de Filosofia:

Eu acho que a disposições e formato da sala de informática quebrava [quebrava a interação professor-aluno], apesar de eu estar sempre sentada no meio deles. Eu sentava com um, sentava com outro, sentava em cada computador. Tinham três ou dois alunos por computador e eu sempre sentava com eles por ali. Mas incomodava eu falar, eu estar dando aula com os meus alunos... Porque era uma aula de computador, enquanto eu estava falando eles estavam mexendo no computador também, por causa da aula mesmo, e eu me sentia falando pro nada, sabe? E aquilo foi me incomodando muito. Aí eu falei: 'eu não posso continuar assim! E isso me motivou a fazer o curso de Filosofia. Eu falei: 'Eu quero dar aula de outra coisa, não quero mais dar aula disso porque eu não consigo mudar isso'. Até em alguns momentos eu discutia essas coisas na coordenação, mas eu não tinha voz, não era ouvida, não era importante pros outros o quanto era importante pra mim. (Raquel, 48 anos, professora do Ensino Médio)

Quando comecei a dar aulas de Filosofia foi legal. Porque na aula de Filosofia eu levava pro pátio, a gente fazia algumas dinâmicas no asfalto, no estacionamento, era muito legal quando a gente saia de sala, sabe? Os alunos gostavam demais quando a gente saia pro pátio pra algumas dinâmicas que a gente podia fazer isso, não é em toda aula. Aí a gente fazia. Sempre gostei muito de movimentar carteiras porque eu trabalho em grupo, trabalho de debates a gente faz círculo, então tem todo esse processo de trabalhar com aquele meio do círculo, com o chão... Eu gosto de usar o chão, pra soltar frases, por coisas ali, por exemplo, o que vou trabalhar... (Raquel, 48 anos, professora do Ensino Médio)

Pergunto se ela reparou que ela repete a cabana.

É minha cabana! é a minha cabana! É a minha análise [no sentido de a entrevista ter valor de uma psicanálise]. Risos. Eu adoro a minha cabana! Então eu jogo as coisas no chão pra provocar, por exemplo, um trabalho que eu quero trabalhar perceptiva, percepção. Então eu ponho os objetos e peço pra cada um escrever o pensamento, então o objeto tá lá no centro, no chão, então os alunos estão vendo de diferentes ângulos $e$ estão falando diferentemente de um mesmo objeto e isso é aula de Filosofia; pra gente discutir, né? Ali é o motivo de discutir. Gosto muito de jogar várias frases de filósofos diversos e cada um da sala partir da frase que tá mais próxima e a gente vai discutindo a diferença dos pensamentos dos filósofos e o tema às vezes até nem é dado. O tema surge das próprias frases, então o chão me aproxima muito, aproxima muito o aluno da 
aula. Aproxima muito. Dá uma mesma distância do aluno pras coisas que eu quero movimentar. Então é a minha cabana, menina! (Raquel, 48 anos, professora do Ensino Médio)

O uso do espaço escolar, principalmente da sala de aula, pela professora Raquel é algo vivido intensamente. Ela percebe, mesmo que intuitivamente, que a relação professor-aluno faz parte da espacialidade. Por um incômodo de não conseguir modificar imposições espaciais ditadas por decisões de departamentos, diretores e conteúdo da disciplina ela procura outra formação (no caso Filosofia) para poder reviver sua cabana: um espaço recheado de sentimentos e interatividade.

O passado conserva-se, além de conservar-se, atua no presente, mas não de forma homogênea. De um lado, o corpo guarda esquemas de comportamento de que se vale muitas vezes automaticamente na sua ação sobre as coisas: trata-se da memória-hábito, memória dos mecanismos motores. De outro lado, ocorrem lembranças independentes de quaisquer hábitos: lembranças isoladas, singulares, que constituíram autênticas ressurreições do passado (BOSI, 1994, p.48).

A memória torna as experiências inteligíveis, produzindo significados. Ao trazer o passado até o presente, recria esse passado.

Mas eu acho que eu trouxe de experiência de... Da minha experiência como aluno, alguma coisas que pra mim foram importantes. Então, por exemplo, eu tento ser muito organizado com o material.

Trouxe experiência principalmente do professor da faculdade. Eu tento fazer um quadro bem organizado porque eu ouço muita queixa de aluno do quadro que outros professores não conseguem organizar.

Eu gosto de andar, não quando eu estou expondo um conteúdo, mas assim, quando eles estão fazendo alguma atividade. Eu passo pelas carteiras, eu gosto de brincar muito com eles no sentido de: 'Poxa, que caderno caprichado!' ou 'Nossa, tá precisando melhorar!', então eu gosto de passar pelos alunos, pelas fileiras. Em geral eu sou bastante... eu brinco muito com eles, mas também chamo pra aula, eu não gosto de conversa durante a minha explicação então eu sou bastante exigente. (Leonardo, 41 anos, professor do Ensino Médio)

Leonardo tem consciência de que suas vivências enquanto aluno influenciam em sua prática docente. Ele relata ter uma atenção especial na organização do material e na organização do espaço do quadro negro. Além disso, ele diz prezar por uma boa relação professor-aluno e para isso circula em sala, faz brincadeira, mas exige respeito. 
“A memória teria uma função prática de limitar a indeterminação (do pensamento e da ação) e de levar o sujeito a reproduzir formas de comportamentos que já deram certo" (BOSI, 2003, p.37).

Nessa perspectiva, Leonardo utiliza-se de estratégias bem sucedidas vividas por seus antigos professores, estratégias essas que lhes agradava enquanto aluno e as repete em sua prática docente.

Sinto que eu aprendi a dar aula com os meus professores. E, eu aprendo também com os colegas. E tem aquela história do professor que vai ao longo da sua profissão, ele vai, mesmo que a suas disciplina seja uma disciplina tradicional, ele vai olhando mais o aluno e menos o quadro... Quando você é um professor jovem, está muito preocupado com o quadro, com o que você está transmitindo. Quando você é um professor mais experiente, você fica muito mais preocupado com as reações dos alunos, sobre o que eles estão recebendo daquilo, como se a minha fidelidade agora é como aluno e não mais com a disciplina. Se precisar assassinar conteúdo, a gente assassina. Quando é verdade, o professor tradicional pra salvar a disciplina, se ele precisar assassinar o aluno, ele assassina!(Eduardo, 50 anos, professor do Ensino Médio)

Eduardo aponta dois fatores para a construção do seu 'eu professor': a relação professor-aluno ser mais importante que o conteúdo e a socialização entre os pares. A socialização entre os pares é uma rede social e coletiva que auxilia na construção de saberes que serão importantes na prática docente. É também pela socialização que o professor pode aprender a habitar e construir representações sobre o espaço escolar.

A socialização é um processo de formação do indivíduo que se estende por toda a história de vida e comporta rupturas e continuidades. [...] Diversos trabalhos biográficos, na maioria das vezes realizados por formadores no âmbito das disciplinas da formação inicial, permitem identificar experiências familiares, escolares ou sociais, citadas pelos alunos e professores, como fontes de suas convicções, crenças ou representações, frequentemente defendidas como certezas, em relação com diversos aspectos do ofício de professor: papel do professor, aprendizagem, características os alunos, estratégias pedagógicas, gestão da classe etc. (TARDIFF; RAYMOND, 2000, p. 217-20).

A escola é um lugar de relação e de construção de subjetividades tanto para os alunos como para os professores. É, também, por meio do habitar esse espaço que são construídas representações sobre o que é espaço escolar, o que é ser professor e o que é ser aluno. 


\subsection{Memórias e Práticas: imagens sobre o espaço escolar}

Nesse item trazemos algumas respostas dos professores quando foram perguntados diretamente se pensam e o que pensam sobre espaço escolar e como eles podem mudá-lo.

É muito difícil compreender a percepção espacial de um professor (e de qualquer outro profissional) sem inseri-lo em suas histórias e trajetórias profissional e educacional que modelam/modelaram sua identidade como docente.

Essa historicidade se expressa e se imprime nos saberes profissionais dos professores e, mais especificamente, nos saberes experienciais adquiridos no início da carreira, que são, parcialmente, uma reativação, mas também uma transformação dos saberes adquiridos nos processos anteriores de socialização (TARDIFF; RAYMOND, 2000, p. 238).

As respostas dos professores foram diversas e demonstraram diferentes formas de percepção do espaço escolar. Oito dos professores entrevistados tinham mais apurada a percepção da parte física do espaço escolar. A formação e escolarização desses professores podem ter influenciado nesse tipo de percepção. Neste grupo estão os professores de Gastronomia, Arquitetura, Administração, Biologia e Física.

Eu acho que [penso] mais na quantidade de alunos do que o espaço em si. Se você tem menos alunos você transforma o seu espaço físico em qualquer tipo de layout. Com uma quantidade maior de alunos você não pode mexer muito. (Eliana, 38 anos, professora do Ensino Superior)

O número de alunos é mais importante que o espaço físico para Eliana, o que indica certa percepção do lado material do espaço escolar, pois ela o considera como algo dado, naturalizado.

Com certeza! Eu vejo, por exemplo, a ergonomia da sala de aula é péssima, nessa sala que eu dou aula de desenho, as pranchetas não são inclináveis, a iluminação não é favorável, por exemplo, ela projeta a sombra do esquadro sobre o desenho quando você tá fazendo e isso atrapalha. A mesa por não se inclinada, o aluno debruça em cima da prancheta, isso atrapalha a coluna do aluno. Então a iluminação, a ergonomia, a disposição da sala, falta de recurso tecnológico, que ainda usa quadro branco e raramente, tem recurso tecnológico disponível. (Raul, 40 anos, Professor do Ensino Superior)

Para Raul, que é arquiteto, o mais importante é o lado técnico e material do espaço. Ele preza a ergonomia, a funcionalidade e o conforto ambiental. Pela fala 
desse professor, percebemos que a formação escolar influência a percepção do que é mais relevante no espaço.

Sete professores responderam que precisam acontecer mudanças no espaço escolar e que essas mudanças podem ajudar a gerar novas formas de educação.

Eu acho que nós é que temos que promover essa mudança. No espaço escolar inclusive, vou falar, que o ambiente físico, eu acho que muda um pouco a questão de os alunos, das relações com o professor e até com os próprios colegas, muda muito.

Agora o que eu tento também fazer pra quebrar paredes da sala de aula, pra sair, é fazer com que eles pesquisem realmente. Eu consigo às vezes fazer com que eles vão às indústrias, nas empresas, nas obras e tal. Em locais pra eles [alunos] conversarem com profissionais. (Tiago, 52 anos, professor do Ensino Superior)

Olha, só de colocar tecnologia em sala de aula o espaço físico da sala vai mudar, mas a maneira de dar aula, não sei se só isso vai mudar... Mas que eu penso, penso que a educação tem que seguir pra esse rumo aí de mudanças eu penso. Porque os alunos estão desesperados pra essa mudança. E a gente também. Mas várias coisas tem que acontecer, entendeu? É a disposição física da sala, é a introdução da tecnologia maior e mais eficaz em sala de aula, mudança nos conteúdos, então são esses vários fatores assim que vão ajudar em sala de aula, no espaço escolar. (Guilherme, 39 anos, Professor do Ensino Médio)

Dois professores, Eduardo e Adriano, têm a percepção de que o espaço escolar vai além do aspecto físico e do simbólico. Para esses professores, o espaço não é naturalizado. A formação desses dois docentes provavelmente influenciou nessa forma de perceber o espaço escolar. Adriano é um estudioso de Foucault e da Cultura visual e Eduardo leu o livro 'A poética do espaço' de Bachelard em seu curso de doutorado.

Eu acho que ele [espaço escolar] é cúmplice, ele é cúmplice dessa prática escolar obsoleta que se pauta unicamente pelo sucesso em exames de acesso. Então na verdade, se eu quero, se eu considero o exame de acesso tradicional uma forma, eu vou avaliar criticamente: é isso que existe é isso que eu vou fazer pro aluno entrar na universidade. Só aceito isso e isso vai me exigir uma aula de transposição de conteúdo e isso vai exigir uma voz monopolista em sala de aula, a voz do professor, $e$ isso vai querer também uma disposição espacial dentro de sala de aula que privilegie, essa forma. Está tudo amarrado. Acho tão engraçado isso que os pais são incapazes de entender outro forma de educação e perguntam: 1Escuta, o caderno do meu filho tá vazio', entendeu? Até o espaço do caderno, que como dizia Clarice Lispector, 'Que a magia e o medo da folha 
em branco...'. A folha não pode estar em branco, a folha deve estar cheia daquela voz, não só você, não só o tempo tem que estar ocupado pela voz monopolista de professor, como o espaço do caderno que seria quase como um decalque do espaço mental interior. Então essa ingenuidade [dos pais] que ainda acreditam que a máxima do bom professor, a máxima de que o aluno esteja aprendendo é o caderno cheio. [...]. Então nesse sentido, quer dizer, uma mudança: no caso o Enem que aponta, requer sim uma mudança completa na composição das carteiras, nas técnicas, nessas técnicas da informática que eles têm que vir pra sala de aula, elas [técnicas da informática] tem que estar imersas. Não pode ser: 'Agora nós vamos pra sala de informática'. Não pode ser assim, elas [técnicas da informática] têm que estar imersas. (Eduardo, 50 anos, professor do Ensino Médio)

Adriano conta de um livro que encontrou na Europa com fotografias de escolas e de visitas que fez a instituições de ensino em outro estado brasileiro:

Nas fotos você vê que são escolas completamente pensadas no espaço escolar. Eu fui também agora pra um evento em Goiânia. Em Goiânia também tem o REUNE [Programa de Apoio a Planos de Reestruturação e Expansão das Universidades Federais - Restauração e Reparação das Universidades Federais] e a universidade tava toda em obra. Fui a um evento na cultura visual [prédio da área de conhecimento Cultura Visual], e aí o coordenador tava me contando a luta que foi convencer... Isso no espaço da universidade... Convencer os órgãos das universidade que estavam destinando dinheiro, a fazer um prédio específico pras artes visuais, uma vez que as artes visuais trabalham com espaços outros. Não é espaço quadrado, padronizado e conseguiram convencer. As artes visuais tá dentro desse espaço, então foi um espaço organizado pelos arquitetos da do curso de arquitetura. Então é um espaço super bem pensado, super legal, foi o espaço mais caro de toda a universidade e o pessoal está 'caindo de pau', criticando esse espaço. Porque as pessoas não conseguem sentir que é um espaço diferente. Que a área de conhecimento precisa de um espaço diferente, porque o curso é um curso que exige outro tipo de relação. Então eu acho que a gente não tem esse hábito, a gente acaba que vai pra escola e não problematiza isso. (Adriano, 44 anos, professor do Ensino Superior)

As instituições de ensino, mesmo estando imersas em um contexto cultural mais amplo, produzem sua própria cultura interna que exprime valores e crenças (NÓVOA, 1995). A homogeneidade de espaços, tempos, processos e saberes faz parte da cultura escolar e tudo que foge a esses padrões tende a ser recebido com certa desconfiança. 


\title{
6. Considerações finais
}

\author{
Nós devemos então contar histórias? A nossa história? \\ É verdade que, ao narrar uma experiência profunda, nós a \\ perdemos também, naquele momento em que ela se corporifica \\ (e se enrijece) na narrativa. \\ Porém o mutismo também petrifica a lembrança que se paralisa \\ e se sedimenta no fundo da garganta como disse Ungaretti no \\ poema sobre a infância que ficou: Presa no fundo da garganta \\ como uma rocha de gritos. (BOSI, 2003, p.35)
}

Para finalizar esse trabalho, mas não encerrar esta discussão sobre o espaço escolar, teço algumas considerações que indicam certas conclusões, que não são um ponto final para o tema, mas sim conclusões que esse trabalho de pesquisa conseguiu alcançar.

A pesquisa não foi elaborada com a intenção de julgar procedimentos ou situações e, menos ainda, de prescrever como deve ser o espaço escolar ou como ele deve ser habitado ou vivido. O que mais importou foi trazer uma inquietação para esse tema e levantar a discussão sobre o espaço escolar.

Não se trata aí de afirmações, quando muito de questões às quais não é possível responder; é preciso deixá-las em suspenso lá onde elas se colocam, sabendo apenas que a possibilidade de as colocar abre, sem dúvida, para um pensamento futuro. (FOUCAULT, 2007, p.535)

O grupo de professores e suas memórias reunidas por essa investigação foram relevantes para a concretização dessa tese. Podemos perceber a escola como um lugar, um espaço que não acaba, como uma ideia e força que ressoam na memória. Nesse sentido, o professor reproduz, mesmo que em parte, os espaços vividos no passado e, portanto, reproduz parcialmente noções de escola, espaço, relação e educação que estão em sua memória.

Tanto o espaço, quanto o trabalho docente e as práticas pedagógicas são construções sociais interdependentes, que são influenciadas pela trajetória de vida, cultura e formação do sujeito. Pelas memórias dos professores sobre o espaço escolar vivido em suas jornadas educativas percebeu-se que as condições e dimensões do trabalho docente estão sujeitas ao limite do espaço físico, infraestrutura e a imposições e decisões superiores (da diretoria e das políticas de exames nacionais) que interferem diretamente na forma de utilizar/habitar o 
espaço escolar. Essas imposições cerceam a autonomia do professor e limitam suas escolhas espaciais como mudanças no layout de sala de aula e proposições de novas formas de abordar o conteúdo. Nessa perspectiva, como os docentes percebem o contexto tecnológico como principal componente das ideias e práticas pedagógicas, eles utilizam a tecnologia para tentar reduzir as limitações impostas e conquistar a atenção dos alunos. Dessa forma, o professor tem que construir sua legitimidade e lidar com a diversidade e multiplicidade de classes e alunos.

O docente pode se sobrepor às imposições do espaço escolar e vencer suas limitações, pois ele é um dos grandes construtores desse espaço. Em contrapartida, a vivência, o habitar cotidiano no espaço escolar pode gerar uma percepção de que este espaço é algo natural e não passível de mudanças.

O conteúdo da disciplina escolar, que também é uma construção imposta aos professores pelo currículo, é visto como um construtor e limitador do uso do espaço escolar. Muitas vezes o professor se sente limitado por esse conteúdo que o prende à aula expositiva e ao uso do quadro negro, o que, para o docente, dificulta fazer modificações no arranjo e relações espaciais.

A partir dessas memórias podemos perceber que os saberes ligados ao magistério são temporais, pois são construídos e dominados progressivamente durante período de aprendizagem e formação (TARDIFF; RAYMOND, 2000), mas podemos falar que também são espaciais, pois os períodos de aprendizagem e de trabalho ocorrem em um espaço específico, com suas materialidades, simbolismos e relações.

O professor tem certa autonomia para desenvolver seu trabalho no que diz respeito à metodologia de suas práticas, mas em relação ao espaço essa autonomia é rara e relativa. Mas essa falta de autonomia nem sempre é percebida, pois muitos dos professores naturalizam o espaço escolar, não percebendo como algo imposto.

Parafraseando Tardiff e Raymond (2000, p.239) quando falam do tempo: o espaço escolar não é, definitivamente, somente um meio - no sentido de um meio físico - no qual estão imersos a educação, o professor, os alunos e seus saberes. Também não é unicamente um dado objetivo caracterizado, por exemplo, pelo formato e/ou disposição dos mobiliários em sala de aula. É também um dado subjetivo, no sentido que contribui poderosamente para modelar a identidade do 
professor. A própria noção de experiência, que está no cerne do eu profissional dos professores e de sua representação do saber ensinar, remete ao tempo e ao espaço no processo de aquisição de certo domínio do que é ser professor. "Uma experiência é sempre uma ficção; é algo que se fabrica para si mesmo, que não existe antes e que existirá depois" (FOUCAULT, 2004, p. 45).

Além de manifestação da diversidade e da complexidade sociais, o espaço escolar constitui uma dimensão fundadora do 'ser professor', que se revela nas didáticas, movimentos, percepções e representações do que é escola, do que é educação e do que é ser um docente. Falar de espaço significa, portanto, visualizar a materialidade que deriva desse processo.

O modelo padrão de escola com salas de aula extremamente parecidas dispostas ao longo de um corredor, modelo esse que apareceu nas memórias do professores entrevistados, é um dispositivo espacial que por meio de uma repetição de formas facilita a aplicação da disciplina, o exercício do controle e a consequente normalização dos sujeitos. A repetição torna-se conveniente e, dessa forma, trabalha-se com o provável e o previsível e, então, se elimina a imprevisibilidade e o que diverge do esperado. Em outras palavras, serão excluídos os alunos, os espaços e professores que não se moldarem a essa representação de espaço escolar.

A configuração das percepções espaciais a partir dos dados coletados mostrou que as marcas deixadas pelo espaço escolar fazem parte da constituição da identidade e da história dos professores. Estas marcas podem ser percebidas quando os professores entrevistados narravam suas vivências e memórias sobre escola.

O que recordamos são espaços que levam dentro de si, comprimido, um tempo. Nesse sentido, a noção de tempo, da duração, nos chega através da recordação de espaços diversos ou de fixações diferentes de um mesmo espaço. De espaços materiais visualizáveis. O conhecimento de si mesmo, a história interior, a memória, em suma, é um depósito de imagens. De imagens de espaços que, para nós, foram alguma vez e durante algum tempo, lugares. Lugares nos quais algo de nós ficou ali e que, portanto, nos pertencem: que são, portanto, nossa história (VIÑAO-FRAGO, 2001, p.63).

Tendo as memórias das vivências dos professores do espaço escolar como instrumento de discussão e reflexão, compreendemos que, ao narrar sobre o espaço efetivamente vivido, se expressa o caráter cultural que envolve o modo de 
representação do espaço escolar enquanto construção social. Dessa forma, não podemos dizer que existe diferença de percepção e vivência do espaço escolar de professores baseada no nível de ensino em que leciona. As diferenças ocorrem devido à toda experiência de vida cultural, social e econômica do usuário do espaço. Além disso, essa pesquisa mostrou indícios de que a memória da primeira escola (da escola da infância) e das modificações ocorridas no espaço escolar são mais fortes que as memórias do que acontecia rotineiramente ou das escolas vividas na adolescência ou juventude.

Compreendo que não esgotei todas as possibilidades de análise do espaço na formação do professor, muito menos a discussão sobre suas representações. Outras pesquisas podem ser realizadas para verificar a vivência e percepção do espaço em uma faculdade de formação de professores, de compreender como o assunto é tratado ou se é tratado durante a graduação em licenciatura. O tema ainda pode ser ampliado e estudado como o espaço influencia a formação do professor de Ensino Fundamental e na condução das disciplinas ou até mesmo tentar compreender como o espaço é ao mesmo tempo subjetivado e mecanismo de subjetivação.

"O espaço tem sido, ao longo do tempo, destinado a cumprir funções específicas que variam segundo as necessidades das organizações sociais em cada época" (REZENDE, 1982, p.19). Quais são as necessidades que o espaço escolar vem atendendo? Deixo essa pergunta para o leitor.

"O espaço se projeta ou se imagina; o lugar se constrói a partir do fluir da vida e a partir do espaço como suporte; o espaço, portanto, está sempre disponível e disposto a converter-se em lugar, para ser construído" (VIÑAO-FRAGO 2001, p. 61). Nesse sentido, as pessoas modificam o espaço com sua presença. "A modificação do espaço [escolar] deve ser uma necessidade; ela é uma possibilidade e seguramente não é um luxo" (COELHO NETTO, 2009, p.70).

Não há como negar a responsabilidade de sermos coprodutores da escola. Nossas memórias e representações sobre o espaço escolar influenciam no nosso 'eu professor'. Pensamos nas nossas escolhas? Criar um espaço escolar que seja bom para todos é uma decisão nossa. 


\section{Referências bibliográficas}

ALVES-MAZZOTTI, Alda Judith. Representações Sociais: aspectos teóricos e aplicações à Educação Em Aberto. Brasília MEC-INEP, ano 14, n ${ }^{\circ}$ 61, p. 60-78, jan/mar. 1994. Disponível em: <http://www.rbep.inep.gov.br/index.php/emaberto/article/viewFile/912/818 >

Acesso em: 04 /02/2011.

BACHELARD, Gaston. A Poética do Espaço. 2 ed. São Paulo: Martins Fontes, 2008.

A poética do devaneio. São Paulo: Martins Fontes, 1988.

BERDOULAY, Vincent. Espaço e Cultura. In: CASTRO, Iná Elias; GOMES, Paulo César da Costa; CORREAA, Roberto Lobato. (orgs.) Olhares Geográficos: modos de ver e viver o espaço. Rio de Janeiro: Bertrand Brasil, 2012.

BERGSON, Henri. Matéria e Memória: Ensaio sobre a relação do corpo com o espírito. 4 ed. São Paulo: WMF Martins Fontes, 2010.

BOSI, Ecléa. O tempo vivo da memória: ensaios de psicologia social. São Paulo: Ateliê Editorial, 2003.

_. Memória e Sociedade: Lembranças de Velhos. São Paulo: Companhia das Letras, 1994.

BRANDÃO, Zaia. Qualidade de ensino característica adstrita às escolas particulares? In.: CUNHA, Luiz Antônio (org). Escolas públicas, escolas particulares e democratização do ensino. São Paulo: Cortez, 1985.

Conversas com Pós-Graduandos. Rio de Janeiro: Forma \& Ação, 2010.

BRITTO, Fabiano de Lemos. Modos de habitar a história ou filosofia, cultura e arquitetura na função do Altes Museum de Berlim. Archivos Analíticos de Políticas Educativas, n. 19, p. 1-25, 2011.

CARIA, Thelmo H. A Cultura Profissional dos Professores: o uso do conhecimento em contexto de trabalho na conjuntura da reforma educativa dos anos 90. Porto: Fundação Calouste Gulbenkian, 2000.

CERTEAU, Michael de. A invenção do cotidiano: Artes do fazer. Petrópolis: Vozes, 1994.

CHARTIER, Roger. A historia cultural: entre práticas e representações. Lisboa: DIFEL, 1990. 
O mundo como representação. Estudos avançados. São Paulo, v.5, n.11, 1991. Disponível em: <http://www.scielo.br/pdf/ea/v5n11/v5n11a10.pdf>. Acesso em 24/02/2013.

COELHO NETTO, J. Teixeira. A Construção do Sentido na arquitetura. São Paulo: Perspectiva, 2009.

COMTE-SPONVILLE, André. O Ser-Tempo. São Paulo: Martins Fontes, 2006.

CORRÊA, Roberto Lobato. Espaço e Simbolismo. In: CASTRO, Iná Elias; GOMES, Paulo César da Costa; CORRÊA, Roberto Lobato (orgs.). Olhares Geográficos: modos de ver e viver o espaço. Rio de Janeiro: Bertrand Brasil, 2012.

DAMATTA, Roberto. A casa e a Rua: espaço, cidadania, mulher e morte no Brasil. 5 ed. Rio de Janeiro: Rocco, 1997.

DORTIER, Jean-François. Dicionário de Ciências Humanas. São Paulo: WMF Martins Fontes, 2010.

DOSSE, François. O Desafio Biográfico: escrever uma vida. São Paulo: EDUSP, 2009.

DUARTE, Cristiane Rose et al (orgs). O Lugar do Projeto: no ensino e na pesquisa em arquitetura e urbanismo. Rio de Janeiro: Contra Capa Livraria, 2007.

ESCOLANO BENITO, Augustín. Las materialidades de la escuela (a modo de prefacio). In.: SILVA, Vera Lucia Gaspar da; PETRY, Marilia Gabriela (orgs). Objetos da Escola: Espaços e lugares de constituição de uma cultura material escolar (Santa Catarina - Séculos XIX e XX). Florianópolis: Insular, 2012.

FONSECA, Cláudia. Quando cada caso NÃO é um caso: pesquisa etnográfica e educação. Revista Brasileira de Educação, n.10, p. 58-78, 1999.

FOUCAULT, Michel. As palavras e as coisas. $9^{a}$ ed. São Paulo: Martins Fontes, 2007.

Ditos e Escritos: Estratégia, Poder-Saber. Rio de Janeiro: Forense Universitária, 2004.

2008a.

A Arqueologia do Saber. 7 ed. Rio de Janeiro: Forense Universitária,

A ordem do discurso. 16 ${ }^{\mathrm{a}}$ Ed. São Paulo: Edições Loyola, 2008b.

Microfísica do poder. $26^{\mathrm{a}}$ ed. São Paulo: Graal, 2008c. 
"De Outros Espaços". In.: Motta, Manoel Barros da (org). Estética: Literatura e Pintura, Música e Cinema. 2ed. Rio de Janeiro: Forense Universitária, 2009a.

Vigiar e Punir: nascimento da prisão. 35 ed. Petrópolis: Vozes, 2009 b. O corpo utópico: as heterotopias. São Paulo: Edições, 2013.

FRANÇA, Lilian Cristina Monteiro. Caos - Espaço - Educação. São Paulo: AnnaBlume, 1994.

FREIRE, Paulo. Pedagogia da Autonomia. 27 ed. São Paulo: Paz e Terra, 1996.

GIEDION, Sigfried. Espaço, Tempo e Arquitetura: o desenvolvimento de uma nova tradição. São Paulo: Martins Fontes, 2004.

HALL, Edward T. A Dimensão Oculta. São Paulo: Martins Fontes, 2005.

HERNADÉZ, Fernando. Educación y Cultura Visual. 2 ed. Barcelona: Octaedro - EUB, 2003.

. "De qué hablamos cuando hablamos de Cultura Visual?", Educação \& Realidade, v. 30, n. 2, p. 9-34, 2005.

LARA, Tiago Adão. Espaço e Educação, na perspectiva antropológica e epistemológica de ser e tempo. In.: LOPES, Jader Janer Moreira; CLARETO, Sônia Maria (orgs). Espaço e Educação: Travessias e Atravessamentos. Araraquara: Junqueira \& Marin, 2007.

LARROSA, Jorge. Tecnologias do eu e educação. In.: SILVA, Tomaz. O sujeito da Educação. Petrópolis: Vozes, 1994.

LE GOFF, Jacques. História e Memória. Campinas: Editora UNICAMP, 2012.

LELIS, Isabel. Profissão docente: uma rede de histórias. Revista Brasileira de Educação, n.17, p. 40-49, 2001.

_. O trabalho docente na escola de massa: desafios e perspectivas. Sociologias, Porto Alegre, v.14, n.29, p. 152-174, 2012.

LOPES, Jader Janer Moreira; CLARETO, Sônia Maria (orgs). Espaço e Educação: Travessias e Atravessamentos. Araraquara; Junqueira \& Marin, 2007.

LOURO, Guacira Lopes. O currículo e as diferenças sexuais e de gênero. In: COSTA, Marisa Vorraber (org.). O currículo nos limiares do contemporâneo. Rio de Janeiro:DP\&A, 2001.

LÜDKE, Menga; BOING, Luiz Alberto. Caminhos da Profissão e da Profissionalidade Docentes. Educação \& Sociedade. Campinas, v. 25, n. 89, p. 
1159-80, 2004. Disponível em: $<$ http://www.scielo.br/pdf/es/v25n89/22616.pdf $>$. Acesso em: 13/07/2011.

MASSEY, Doreen. Filosofia e Política da Espacialidade: algumas considerações. Geographia, Niterói, n.12, p.7-23, 2004.

NÓVOA, Antonio (org.). Profissão professor. Porto: Porto Editora, 1999. 1995. (coord.). As Organizações escolares em análise. Lisboa: Dom Quixote,

PERRENOUD, Philippe. Construir competências desde a escola. Porto Alegre: Artmed, 1999.

POLLAK, Michael. Memória e identidade social. Estudos Históricos. Rio de Janeiro, v. 5, n. 10, p. 200-212, 1992.

RIBEIRO, Cláudia R. Vial. A dimensão simbólica da arquitetura: parâmetros intangíveis do espaço concreto. Belo Horizonte: Editora com Arte, 2003.

SAMPAIO, Maria. M. Ferreira; MARIN, Alda Junqueira. Precarização do Trabalho Docente e seus efeitos sobre as Práticas Curriculares. Educação \& Sociedade. Campinas, v. 25. n. 89, p. 1203-25, set./dez. 2004. Disponível em: <http://www.scielo.br/pdf/es/v25n89/22618.pdf>. Acesso em: 22/05/2011.

SANTOS, Milton. A natureza do espaço. São Paulo: Editora da Universidade de São Paulo, 2008a.

Da Totalidade ao Lugar. São Paulo: Editora da Universidade de São Paulo, 2008b.

2012.

Espaço e Método. São Paulo: Editora da Universidade de São Paulo,

SILVA, Vera Lucia Gaspar da; JESUS, Camila Mendes de; FERBER, Luiza Pinheiro. O mínimo necessário: mobiliário escolar de escolas isoladas (Santa Catarina, 1910 - 1920). In.: SILVA, Vera Lucia Gaspar da; PETRY, Marilia Gabriela (orgs). Objetos da Escola: Espaços e lugares de constituição de uma cultura material escolar (Santa Catarina - Séculos XIX eXX). Florianópolis: Insular, 2012.

TARDIF, Maurice; LESSARD, Claude. O trabalho docente: elementos para uma teoria da docência como profissão de interações humanas. 4. ed. Petrópolis: Vozes, 2008.

TARDIFF, Maurice; RAYMOND, Danielle. Saberes, tempo e aprendizagem do trabalho no magistério. Educação \& Sociedade. Campinas, n. 73, p. 209-244, dez. 2000. Disponível em: 〈http:// http://www.scielo.br/pdf/es/v21n73/4214>. Acesso em: 22/11/2014. 
TUAN, Yi-Fu. Topofilia: um estudo da percepção, atitudes e valores do meio ambiente. São Paulo: DIFEL, 1980.

TUAN, Yi-Fu. Espaço e Lugar: a perspectiva da experiência. São Paulo: DIFEL, 1983.

VEIGA-NETO, Alfredo. As duas faces da moeda: heterotopias e emplazamientos curriculares. Educação em Revista, Belo Horizonte, n.45, p.249-264, 2007. Disponível em: <http://www.scielo.br/scielo.php?script=sci_arttext\&pid=S010246982007000100013\&lng=pt\&nrm=iso >. Acesso em: 10/11/2008.

- Pensar a escola como uma instituição que pelo menos garanta a manutenção das conquistas fundamentais da Modernidade. In: COSTA, Marisa Vorraber (org). A escola tem futuro? Rio de Janeiro: DP\&A, 2003.

VIÑAO-FRAGO, Antônio; ESCOLANO, Agustín. Currículo, Espaço e Subjetividade: a arquitetura como programa. Rio de Janeiro: DP\&A editora, 2001.

VIGOTSKI, Lev Semenovich. Psicologia Pedagógica. São Paulo: Martins Fontes, 2001.

WORMS, Frédéric. Bergson ou os dois sentidos da vida. São Paulo: Editora Unifesp, 2010.

ZABALZA, Miguel A. A organização dos Espaços na Educação Infantil. In.: ZABALZA, Miguel A. Qualidade em Educação Infantil. Porto Alegre: Artmed, 1998. 


\section{Anexo}

\section{ROTEIRO PARA ENTREVISTA}

\section{Caracterização}

Nome

Idade ou faixa etária

Local onde mora

Formação

Área de docência

Tempo de docência

Escola (s) que leciona

O que faz na hora de lazer ${ }^{37}$

\section{Vivência do espaço escolar enquanto aluno}

- Fale sobre a sua jornada educacional ensino fundamental e médio:

Estudou em quais escolas,

Onde morava,

Gostava da escola,

Como eram as aulas,

Como eram seus professores,

Descrever sua aula preferida,

Fale sobre seu professor preferido,

Descrever a aula que não gostava,

Fale sobre o professor que você menos gostava,

\footnotetext{
${ }^{37}$ Esse item foi inserido como uma pesquisa exploratória para uma pesquisa futura.
} 
Descrever a escola,

Descrever a sala de aula,

O que mais gostava na escola,

Fale sobre os espaços preferidos,

Fale dos espaços que não gostava.

- Fale sobre os tempos de faculdade:

Onde cursou,

Porque escolheu o curso e a faculdade,

Matérias preferidas,

Via diferença entre o formato de aula da faculdade e do ensino médio,

Como eram as aulas,

Descreva sua aula favorita,

Como eram seus professores,

Fale sobre seu professor favorito,

Descreva sua faculdade.

\section{Vivência do espaço escolar enquanto professor}

Fale sobre suas aulas,

Descreva suas salas de aulas (são diferentes entre elas, o que as diferencia, o que as assemelha, inspira em algum professor do passado para dar aulas),

Quantos alunos por sala (cabem bem na sala, precisaria de uma sala maior, o número de alunos influencia na forma de conduzir a aula?),

Ministra aulas fora da sala de aula (porque? Vantagens, desvantagens), Privilegia trabalho em grupo ou individual? Modifica o lay out da sala?

A forma com você ministra aulas é semelhante às aulas dos seus antigos professores (sim, em que? Não, em que?),

Pensa sobre o espaço escolar, como você pode mudá-lo?

Se falar em disciplina: O que é disciplina para você? Disciplina é fundamental? 